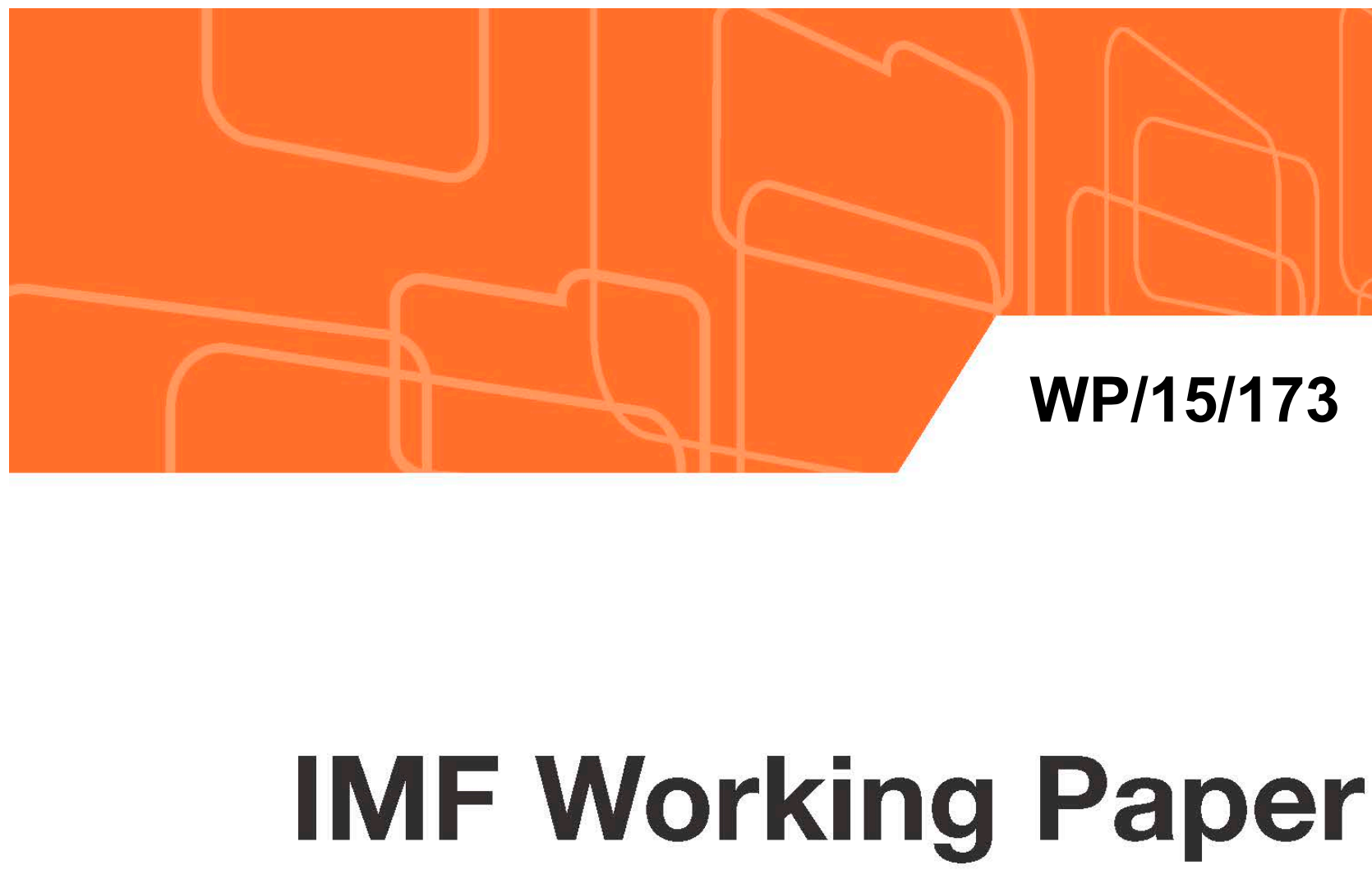

\title{
What Matters for Financial Development and Stability?
}

by Raja M. Almarzoqi, Sami Ben Naceur, and Akshay Kotak

IMF Working Papers describe research in progress by the author(s) and are published to elicit comments and to encourage debate. The views expressed in IMF Working Papers are those of the author(s) and do not necessarily represent the views of the IMF, its Executive Board, or IMF management.
I $\mathbb{N}$
$N$ T E R
R N A T I O N A L
M O N E T A R Y
F U N D 


\title{
IMF Working Paper
}

Middle East and Central Asia Department

\author{
What Matters for Financial Development and Stability? \\ Prepared by Raja M. Almarzoqi, Sami Ben Naceur, and Akshay Kotak ${ }^{1}$ \\ Authorized for distribution by Raja M. Almarzoqi
}

July 2015

\section{IMF Working Papers describe research in progress by the author(s) and are published to elicit comments and to encourage debate. The views expressed in IMF Working Papers are those of the author(s) and do not necessarily represent the views of the IMF, its Executive Board, or IMF management.}

\begin{abstract}
This study aims to identify policies that influence the development of financial institutions as measured across three dimensions: depth, efficiency, and stability. Applying the concept of the financial possibility frontier, developed by Beck \& Feyen (2013) and formalized by Barajas et al (2013a), we determine key policy variables affecting the gap between actual levels of development and benchmarks predicted by structural variables. Our dynamic panel estimation shows that inflation, trade openness, institutional quality, and banking crises significantly affect financial development. Our analysis also helps identify potential complementarities and trade-offs for policy makers, based on the effect of the policy variables across the different dimensions of financial development.
\end{abstract}

JEL Classification Numbers: E44; E52; F6; G2; O16

Keywords: financial development, financial stability, financial possibility frontier

Author's E-Mail Address: ralmarzoqi@imf.org; sbennaceur@imf.org; akshay.kotak@sbs.ox.ac.uk.

\footnotetext{
${ }^{1}$ The authors would like to thank Adolfo Barajas, Alberto Behar, Enrica Detragiache, Raphael Espinoza, Alessandro Giustiniani, Camelia Minoiu, Pritha Mitra, Natalia Tamirisa, and participants at the Middle East and Central Asia Department seminar for helpful comments; Neil Hickey and Kia Penso for editorial assistance; Fatima Keaik, Patricia Poggi and Cecilia Prado for administrative assistance. All errors and omissions are our own.
} 


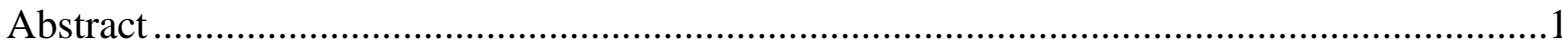

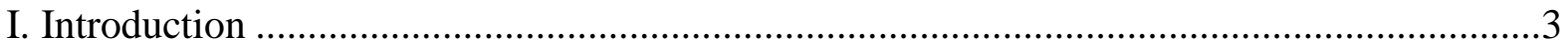

II. The Financial Possibility Frontier ........................................................................

III. Determinants of Financial Development ...........................................................

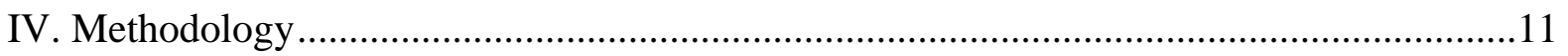

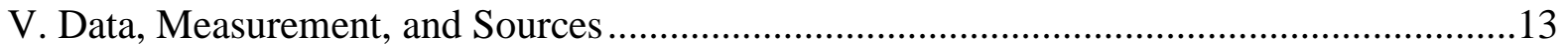

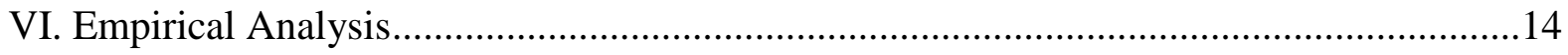

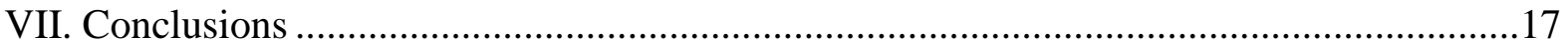

Tables

2a. Summary Statistics and Correlations: Banking Sector Depth (gap analysis), Global

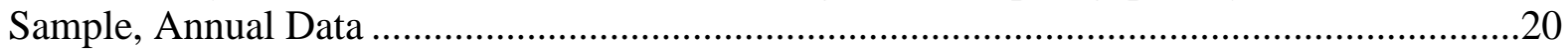

2b. Determinants of Banking Sector Depth (gap analysis) .............................................21

2c. Robustness Checks: Determinants of Banking Sector Depth (gap analysis) ....................22

3a. Summary Statistics and Correlations: Banking Sector Efficiency (gap analysis), Global

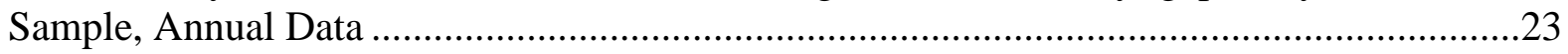

3b. Determinants of Banking Sector Efficiency (gap analysis) .........................................24

3c. Robustness Checks: Determinants of Banking Sector Efficiency (gap analysis) ..............25

4a. Summary Statistics and Correlations: Banking Sector Stability (gap analysis), Global

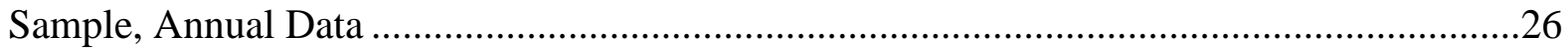

4b. Determinants of Banking Sector Stability (gap analysis) ...........................................27

4c. Robustness Checks: Determinants of Banking Sector Stability (gap analysis) ................28

5a. Summary Statistics and Correlations: Banking Sector Depth, Global Sample, Annual

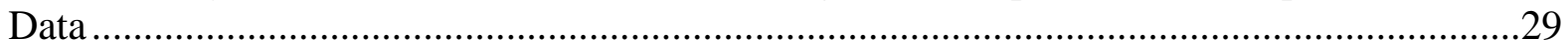

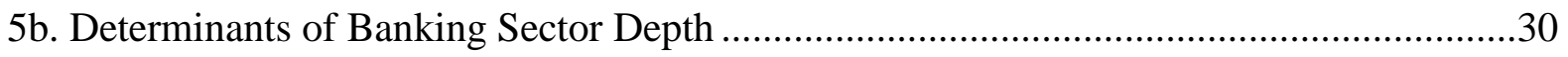

5c. Robustness Checks: Determinants of Banking Sector Depth ........................................31

6a. Summary Statistics and Correlations: Banking Sector Efficiency, Global sample, Annual

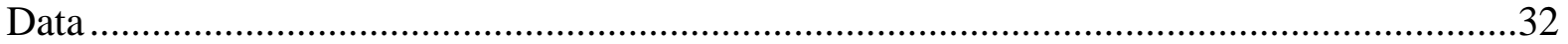

6b. Determinants of Banking Sector Efficiency .................................................................33

6c. Robustness Checks: Determinants of Banking Sector Efficiency ...................................34

7a. Summary Statistics and Correlations: Banking Sector Stability, Global Sample, Annual

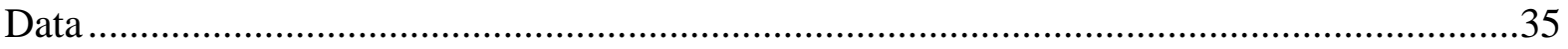

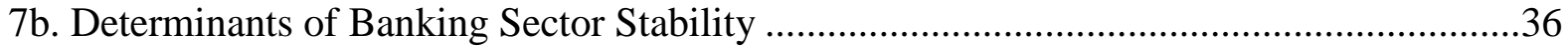

7c. Robustness Checks: Determinants of Banking Sector Stability .....................................37

8. The Impact of Policy Variables on the Different Dimensions of Financial Development..38

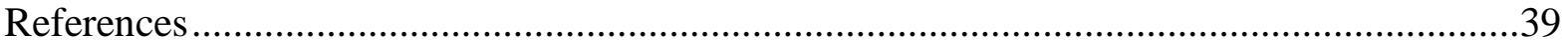




\section{INTRODUCTION}

The debate on the effects of finance on economic growth has been active for decades, raising opinions ranging from inconsequential and "very badly over-stressed" (Lucas, 1988) to seemingly obvious (Miller, 1998). Bagehot (1873) and Schumpeter (1911) have argued, more conservatively, that the interplay between finance and growth is positive and non-trivial. Goldsmith (1969) was one of the first studies to empirically investigate this relationship, finding a positive correlation between financial development (as measured by the size of the financial sector) and long-run growth. He (and later, Bencivenga \& Smith, 1991) explained this correlation by asserting that intermediation leads to savings being better channeled into productive investment. In their treatises on financial liberalization, Shaw (1973) and McKinnon (1973) posited that eliminating financial repression would enhance growth, as the elimination of interest rate ceilings would increase the quantity of savings in the economy. However, these studies did not address the issue of causality in either direction.

One of the first attempts at demonstrating that the financial system promotes economic growth was by King \& Levine (1993), who found that indicators of financial development strongly correlated with growth, and that these indicators also had significant power in predicting future growth rates. Rajan \& Zingales (1998) found a similar causal link between financial development and growth by showing that the development of financial intermediaries and markets has a disproportionately large positive effect on sectors more dependent on external financing. Levine et al (2000) provided further evidence of this finance-growth causality through instrumented variable procedures, using the difference in legal and accounting systems across countries as instruments. Beck et al (2000) incorporated dynamic panel techniques (difference and system GMM estimators) to further strengthen their argument that financial intermediaries exert a large positive impact on factor productivity growth. Furthermore, Levine \& Zervos (1998) examine the contribution of the development of financial markets to growth, finding that the development of financial institutions - banks and financial markets - promotes growth, capital accumulation, and increased productivity, even after controlling for economic and political factors.

It is therefore now widely accepted that financial institutions positively influence economic development and growth. A healthy financial system helps channel household savings into value-creating investments, monitors borrowers to increase efficiency, helps agents pool, share and diversify risk, and facilitates trade. Levine (1997), Levine (2005), Demirgüç-Kunt \& Levine (2008), Beck (2012), and Barajas et al (2013b) provide detailed surveys of the literature on the finance-growth nexus.

In addition, there is another large body of literature that studies the role of financial development in reducing inequality. Beck et al (2007) find that the long-run impact of financial development on the income of the poorest quintile stems from both an increase in aggregate growth effect and a reduction in income inequality. Jalilan \& Kirkpatrick $(2002,2005)$ find a similar poverty reducing effect of financial development in low-income countries. Jeanneney \& Kpodar (2011) argue that financial development helps alleviate poverty through the aggregate growth channel and through the McKinnon (1973) conduit effect. However, they also warn that financial development breeds instability, which serves to negate some of the benefits of financial development on poverty reduction, and find 
evidence for both their hypotheses in a panel of data from developing countries. This highlights another fairly well-accepted theme in the finance-growth literature - that the relationship between financial development and growth is not monotonic.

Academic literature notes several different forms of non-linearity in the relationship between financial development and economic growth. Rioja \& Valev (2004) find that the marginal effect of additional financial development on growth is dependent on the current level of financial development, with uncertain effects at the very low end of the spectrum (i.e. low levels of development), a large positive effect in economies with an intermediate level of financial development, and a smaller positive effect in developed financial systems. Aghion et al (2005) similarly find that economies above a certain threshold of financial development face a positive (and diminishing) return from additional financial development and converge to the same level of long-run growth, whereas those below the threshold attain a lower level of long-run growth. Demetriades \& Law (2006) highlight the importance of institutions to the functioning of the finance-growth nexus. Using a panel data set from 72 countries, they find the magnitude of the effect of financial development on economic growth in an economy is directly tied to the quality of the institutional framework in that economy, with the relationship particularly weak in poor institutional settings.

While a burgeoning financial sector can boost growth opportunities, excessive and rapid expansion can also create instability and lead to crises. The empirical analysis of Arcand et al (2012) suggests that beyond a certain size, development of the financial sector starts having a significant negative effect on growth, even after controlling for volatility, crises, and other institutional factors. Dabla-Norris \& Srivisal (2013) study the relationship between macroeconomic volatility and financial development in a sample of 110 countries and find that financial development acts as a shock absorber against volatility but only up to a point; beyond a certain level, financial systems exacerbate shocks and increase volatility. In a remarkably prescient paper, Rajan (2005) warned that rapid development of the financial sector increases its capacity to bear risk, but also increases the actual level of risk taken, increasing systemic risk and leaving the entire financial sector more vulnerable to left tail events. Beck et al (2012) analyze micro and macro data from 32 developed economies and find that increased levels of financial innovation between 1996 and 2006 were associated with both increased levels of economic growth, and increased levels of economic volatility and idiosyncratic bank fragility. In light of these tradeoffs, recent studies ${ }^{2}$ have put forward the idea of an "optimal" level of financial development for an economy.

Building on the work of Beck \& de la Torre (2007) and Beck \& Feyen (2013), Barajas et al (2013a) formalize this idea through the concept of the financial possibility frontier. They posit that the level of financial development in a country depends on both structural characteristics such as income, population, demographics, and other fundaments that are outside policy control in the short to medium run, and on policy and institutional variables.

\footnotetext{
${ }^{2}$ See Beck \& de la Torre (2007), Beck et al (2008), Beck \& Feyen (2013), and Barajas et al (2013a).
} 
To support this argument, they construct benchmarks based on such structural variables and relate the gaps between the predicted benchmarks and actual values of financial development, measured as the depth of the financial sector, to a host of policy and institutional variables using cross-country ordinary least squares (OLS) regressions. They also show that sustained overshooting of the benchmark is associated with a significant increase in the probability of a bad credit boom, lending further credence to the idea of optimizing financial development, instead of maximizing it.

Furthermore, financial systems are multidimensional. The very idea of financial development itself merits more elaborate treatment than to just proxy it with financial depth or the size of the banking sector ${ }^{3}$. While financial depth remains the most widely researched and widely reported measure of financial development, recent benchmarking studies ${ }^{4}$ outline a more well-rounded approach to assessing financial development by measuring it along four dimensions - depth, access, efficiency, and stability.

In this paper, we seek, in two ways, to extend and improve the analysis carried out by Barajas et al (2013a). Firstly, we extend the analysis to three dimensions of financial developmentdepth, efficiency, and stability_-based on the availability of data and benchmarks. This provides a more rounded assessment of the effects of policy on financial development and also brings to light possible complementarities and trade-offs in the way different policy measures affect different dimensions of financial development. Our choice of indicator variables for the different dimensions is driven by data coverage and the availability of benchmarks. We use private credit as a percentage of GDP as the indicator for depth, net interest margin as the indicator for efficiency, and non-performing loans as a percentage of total gross loans as the indicator for stability. While these are standard, widely-used indicators of financial development, for robustness checks (available on request) we also reran the regressions reported in Tables 5-7b using other theoretically appropriate indicators, including domestic deposits to GDP, banks' assets to GDP, banks' cost to income ratio, lending to deposit spread, banks' Z-score, and private credit to deposits ratio ${ }^{5}$. The size and the significance of the estimated coefficients vary, but these robustness tests serve to confirm our broad findings.

Secondly, we make use of annual data in order to maximize our use of the data set and better identify the policies of interest. This necessitates the use of a dynamic specification to allow for adjustments towards a steady state, since development indicators exhibit a high degree of persistence when measured annually. We therefore include a lagged regressand in the right hand side of our specification and employ dynamic generalized method of moments (GMM) estimators, allowing for endogeneity in the model. The current constraint on the availability of benchmarking data limits our analysis to banking institutions, and to indicators of banking

\footnotetext{
${ }^{3}$ Honohan (2004) highlights some of the inadequacies of proxying financial development solely with financial depth and proposes more composite measures of development that better summarize its multidimensionality.

${ }^{4}$ See Beck et al (2008), Čihák et al (2012), Beck \& Feyen (2013), and Feyen et al (2013).

${ }^{5}$ Since we did not have benchmarks available for all these alternate indicators, the regressions done on these indicators are only done using the second model specification discussed in Section 4.
} 
sector development. However, the considerable breadth and depth of coverage of the indicators we analyze makes the results of this study relevant to a large set of countries, and in particular, to developing countries where the banking sector makes up a large part of the formal financial sector.

Our dynamic panel estimation shows that inflation, trade openness, institutional quality, and the occurrence of banking crises significantly affect the different dimensions of financial development. Moreover, while most of these policy variables have a complementary effect across the different dimensions, some others have a contradictory effect posing a trade-off for policy makers ${ }^{6}$.

This paper contributes to several strands of literature. We further the idea of the financial possibility frontier, and more broadly of benchmarking, as an important conceptual tool to assess the health of the financial systems of countries, and to guide the course of policy measures. This builds on the work of Beck \& de la Torre (2007), Barajas et al (2013a), and Beck \& Feyen (2013) on the financial possibility frontier, and of Beck et al (2008) and Feyen et al (2013) on benchmarking the financial sectors of countries across different dimensions of development. Additionally, we identify the effects of various policy variables on the different dimensions of financial development, thereby providing a more nuanced assessment of their impact on wider financial development and highlighting potential complementarities and trade-offs ${ }^{7}$. This contributes to the large body of literature on the determinants of financial development which we review in section 3 of this paper. Moreover, we employ panel data techniques to better exploit the cross-sectional, and time-series variation, of recent data and provide a more technically sound analysis of the policy determinants of financial development.

The rest of the paper is organized as follows. Section 2 elaborates on the concept of the financial possibility frontier. Section 3 discusses relevant literature on the determinants of financial development. Section 4 outlines the empirical strategy employed in this paper, including the specification of the dynamic model and appropriate estimation techniques. Section 5 describes the data used in the analysis. Section 6 reports the estimation results, and robustness checks employed. Section 7 features our conclusions.

\footnotetext{
${ }^{6}$ Our analysis assumes that the different dimensions of financial development are orthogonal to each other. Since we regress each dimension with the same set of policy and institutional variables, we assess complementarities and trade-offs based on the signs of the estimated coefficients of each regressor with each of the different dimensions of financial development.

${ }^{7}$ Our analysis of the complementarities and trade-offs faced by policy makers is admittedly basic. A more detailed study of such complementarities and trade-offs, employing interaction terms and other extensive analysis of correlations among different policy variables, is beyond the scope of our paper but would be an interesting topic for further research.
} 


\section{The Financial Possibility Frontier}

Financial intermediaries arise in economies due to the presence of market frictions that restrict the free flow of capital from savers to borrowers. Uncertainty, informational asymmetries and limited enforceability, transaction costs, and network externalities are some of the frictions that necessitate the presence of intermediaries. The presence of uncertainty in a world of risk-averse agents yields a demand for the pooling and sharing of risk and for diversification and insurance. The costs of assessing and monitoring potential investments, and of drawing out and enforcing contracts, give rise to financial institutions that specialize in these informational and legal services. Fixed costs associated with financial transactions give rise to economies of scale and are another contributing factor to the emergence of specialist intermediaries. However, financial intermediaries do not completely eliminate these market imperfections, and the very frictions that facilitate their emergence and the demand for their services, also limit the efficiency of their operations and the supply of such services.

Intermediaries themselves face fixed costs, including costs involved in setting up physical branches, computer networks, and legal, accounting, security and support services. While the marginal influence of these costs diminishes as the demand for financial services increases, these substantial fixed costs pose an initial hurdle for the emergence and development of intermediaries. Moreover, in light of recent technological advances and an increase in financial globalization, financial services are beginning to exhibit properties of network goods $^{8}$. This network effect acts as a barrier to new entrants and increases the market power of incumbent intermediaries, thereby producing an externality in the supply of financial intermediation. Further, intermediaries also face risk, notably that of default, and their ability to diversify such risk is another supply side constraint.

The first use of a frontier framework to denote a constrained optimal level of intermediation based on demand and supply side frictions was in Beck \& de la Torre (2007). They study the different constraints on the demand and supply side that influence the access to financial services in an economy, and design an access frontier framework. The central tenet of this framework is that the maximum level of financial access that an economy can sustain at a certain point in time is dependent on a number of state variables. Beck \& Feyen (2013) and Barajas et al (2013a) expand this analysis to other dimensions of financial development and formulate the financial possibility frontier. This framework uses the concept of state variables to define the financial possibility frontier as "a rationed equilibrium of realized supply and demand, variously affected by market frictions." To elaborate, the frontier denotes the maximum sustainable level of the development of an economy's financial system at any given time. It may vary, depending on the nature of underlying frictions, for different types of financial markets, and it may be measured across several dimensions of financial development.

\footnotetext{
${ }^{8}$ See Claessens et al (2003).

${ }^{9}$ Barajas et al (2013a), pg 6.
} 
Based on the position of a country's financial system relative to the financial possibility frontier, Beck \& Feyen (2013) and Barajas et al (2013a) define three different types of policies to effect long-term financial development. Market developing policies, such as legal and structural reforms and long-run changes in fiscal performance, help push the financial possibility frontier of an economy outwards. Market enabling policies help push countries towards the frontier, and include short to medium term policies such as macroeconomic policy measures (inflation targets, growth rate, etc.), regulatory reforms (banking regulations, tax and competition policy), and financial and trade openness. Finally, market harnessing policies are measures put in place to ensure a country does not consistently overshoot its frontier. Such policies include risk oversight and macro-prudential management, and programs to increase financial literacy and the protection of consumers' rights. The focus of our study is primarily on market enabling policies. We seek to understand which short to medium term policy and institutional variables significantly affect the different dimensions of financial development.

While the intuition behind the financial possibility frontier is appealing, mathematically formalizing this concept is a tougher task. To this end, the authors use structural benchmarks, building on earlier work by Beck et al (2008) and Čihák et al (2012). These benchmarks employ a large cross-country panel to produce time varying benchmarks for various financial development indicators, based on a number of structural variables that are invariant in the short-run and assumed to lie outside the domain of policy makers. This benchmark is not a direct proxy for the financial development frontier but, instead, isolates the structural element of financial development with the remainder being a function of policy and institutional factors ${ }^{10}$. Barajas et al (2013a), focus their analysis on financial depth as measured by private credit (extended by banks and other financial institutions) as a fraction of GDP. They calculate benchmarks for a large panel of data and define the financial depth gap as the difference between the benchmark for a given year and the actual value of the indicator for that year. They then run a host of cross-country OLS regressions on the average gap over 2003-07 to identify policy and institutional determinants of financial depth.

This analysis makes a few assumptions that merit clarification. Firstly, the benchmarking exercise and subsequent gap analysis assumes that the benchmark accounts for all key structural variables. This methodology, therefore, does not account for initial conditions that may affect the path of financial development. In other words, two countries with the same structural variables in a year will have the same benchmark, irrespective of their origins. In light of the uniqueness of individual countries' structural and institutional natures, and the occurrence of financial crises and leapfrogging, this assumption may not necessarily hold. Moreover, the benchmarks are based on the notion of (the development path of) the "median country". Given the heterogeneity within countries, this implies that the policies identified as influencing financial development (in the gap analysis) may significantly vary in relative importance between countries, and over time. It must therefore be noted that this exercise serves primarily to broadly identify policies that influence financial development. More

\footnotetext{
${ }^{10}$ Including institutional factors in the benchmarking regression would raise the issue of endogeneity, which we address in our analyses by the use of dynamic panel estimators. See Section 4 for more details.
} 
detailed analyses need to incorporate a more nuanced approach, accounting for countryspecific factors.

The structural variables used in the benchmarks created by Feyen et al (2013) ${ }^{11}$, which we use in our analyses, are broadly classified as follows:

- Economic Development

- GDP per capita

- Square of GDP per capita

- Demographics

- Population size

○ Population density

- Age dependency ratio, old

- Age dependency ratio, young

- Special circumstances

O Offshore financial centre dummy

○ Oil exporter dummy

○ Transition economy dummy

Economic development influences financial development from both the supply and demand side. Higher income increases the demand for the amount and variety of financial intermediation. Intermediaries in wealthier economies are also able to exploit economies of scale better. Demographics also affect the various market frictions affecting the demand and supply of financial services. A larger population implies a larger potential market for intermediation and also an increased potential for economies of scale in the provision of such services. A high population density further facilitates the supply of financial services by reducing fixed costs, and through the network effect. Age dependency ratios are good indicators of saving and lending patterns that influence the demand for intermediation. Revenues from oil exports tend to increase national income disproportionately as compared with financial development, and this is accounted for by the oil exporter dummy variable. Similarly, offshore financial centers have a disproportionately larger financial sector that needs to be accounted for. In addition, the benchmarks also incorporate time dummies to tease out global cycle effects within the pooled regressions.

\section{DETERMINANTS OF FINANCIAL DEVELOPMENT}

The ubiquity of the emergence of financial systems and intermediaries in societiesworldwide and over history - underscores the importance of the services they provide. This has made financial systems and their development an age-old topic of study and research. Moreover, the importance of the financial sector to economic growth, and to the distribution

\footnotetext{
${ }^{11}$ These benchmarks are obtained by quantile (median) regressions, to reduce the impact of outliers.
} 
of economic opportunities, makes understanding and managing its development all the more paramount. There is a vast body of economic literature focusing on the determinants of financial development. As discussed in Section 2, the financial possibility framework broadly divides these determinants along two lines: a set of policy-invariant structural variables and policy and institutional variables. The set of structural variables used in our analysis, is highlighted in Section 2 above. We survey below, some of the literature on the policy and institutional determinants of financial development.

Institutions and the legal and regulatory environment are one of the most studied factors that promote the development of a healthy financial system. La Porta et al (1997), Levine (1998), and Levine et al (2000) find that financial development is stronger in economies where institutions better protect and enforce property rights and reinforce the rights of creditors. Further, Acemoglu et al (2005) and Demetriades \& Andrianova (2005) also find that the existence and quality of institutional checks and balances significantly influences crisis mitigation and the success of financial reforms.

Another strand of literature focusing on the political economy of financial development argues that financial development is constrained in economies where a narrow elite or interest groups exert significant pressures on the shaping of policy and reforms. Rajan \& Zingales (2003) hypothesize that opening up an economy to international trade and finance may weaken the political influence of incumbents and promote financial development. They corroborate this hypothesis by showing, in a global sample, that financial development and trade openness are positively correlated when cross-border flows are high. Their work also emphasizes the influence of institutions on the impact of interest group activity and reiterates the importance of institutions on financial development. Chinn \& Ito (2006) show that financial openness (capital account liberalization) positively influences financial development, albeit only after a certain level of institutional and legal development has been attained. Baltagi et al (2009) further examine the Rajan-Zingales hypothesis using data from developing and developed countries, as well as dynamic panel estimation techniques, and find that both financial and trade openness are significant determinants of banking sector development. Girma \& Shortland (2007) examine the effects of democracy characteristics and regime change on the financial development of countries using panel data. Their analysis shows that regime stability and fuller democracy promote financial development.

Macroeconomic stability is essential for the smooth functioning of a financial system. Higher inflation reduces real returns and makes investment and saving less attractive. Boyd et al (2001) find that countries with endemic inflation problems experience significantly lower levels of financial development. Rousseau \& Wachtel (2006) similarly find that lower inflation aids financial development, and that the finance growth nexus breaks down in economies with inflation rates consistently over $13 \%$. Recent studies have also looked at the importance of remittances in promoting the development of the financial sector, particularly in developing countries. Aggarwal et al (2011) use a broad panel and dynamic estimates to find robust evidence of a significant and positive influence of remittances on financial development. There is mixed evidence of the impact of competitiveness on development. Beck (2008) concludes that empirical studies focusing on individual countries show 
ambiguous results, whereas cross-country studies (such as Peira \& Moody, 2004) find a significantly positive effect.

Based on the literature surveyed above, we use the following policy variables in our analyses:

- Macroeconomic variables

○ (Real) growth rate

$\circ$ Inflation rate

- Remittance inflows

- Banking crisis dummy

- Openness variables

○ (De jure) financial openness

- Trade openness

- Institutional variables

- Polity score

- Composite risk rating

- Market power / competitiveness ${ }^{12}$

$\circ$ Lerner index

A more detailed description of the variables and the data follows in section 5.

\section{Methodology}

\subsection{Model specification}

The aim of this study is to identify the key policy determinants of three different dimensions of financial development. To this end, we attempt to make the utmost use of the depth (timeseries) and breadth (cross-section) of the available panel data. Using annual data necessitates the use of a dynamic specification. Moreover, financial development data are usually very persistent, further pushing for the inclusion of dynamics. We therefore specify the following dynamic model, based on the gap analysis of Barajas et al (2013a):

$\operatorname{Gap}_{i, t}=\alpha \operatorname{Gap}_{i, t-1}+\boldsymbol{P}^{\prime}{ }_{i, t} \boldsymbol{\beta}+u_{i, t}$

where Gap is the relative deviation (from the structural benchmark) ${ }^{13}$ of an indicator of a specific dimension of financial development, and $\boldsymbol{P}$ is the vector of policy variables outlined in Section 3. The error term $u_{i, t}$ has three components:

\footnotetext{
${ }^{12}$ Used only in the analysis of the efficiency dimension of financial development
} 
$u_{i, t}=\mu_{i}+\varepsilon_{t}+v_{i, t}$

where $\mu_{i}$ are the fixed effects, $\varepsilon_{t}$ are the time varying global components and $v_{i, t}$ are the independent, mean zero (idiosyncratic) error terms.

As mentioned in Section 2, one of the main criticisms of the gap analysis is the fact that the benchmark assumes that all structural variables are accounted for. The ramifications of this assumption are particularly severe if one of the omitted variables is correlated with the policy variables $\boldsymbol{P}$ used in the subsequent estimations. As a check against this possibility of biased estimates, we also estimate the model below:

$F D_{i, t}=\alpha F D_{i, t-1}+\boldsymbol{S}_{i, t}^{\prime} \boldsymbol{\beta}+\boldsymbol{P}^{\prime}{ }_{i, t} \boldsymbol{\gamma}+u_{i, t}$

where $F D$ is the level of an indicator of a specific dimension of financial development, $\boldsymbol{S}$ is a vector of structural variables ${ }^{14}$, and $\boldsymbol{P}$ is the vector of policy variables outlined in section 3 . The error term again consists of fixed effects, time varying global components and independent, mean zero (idiosyncratic) error terms.

In both specifications, we tease out the time varying global effects $\varepsilon_{t}$ through a set of time dummies.

\subsection{Dynamic panel GMM estimation}

In the model specifications above, the lagged regressand included in the right hand side is endogenous to the fixed effects in the error term. The lagged regressand depends on $u_{i, t-1}$ which in turn depends on $\mu_{i}$ - the fixed effect for country $i$. OLS and fixed effects estimates for such specifications, therefore, suffer from dynamic panel bias as demonstrated in Nickell (1981). The most popular strategy to circumvent this endogeneity problem is to use the difference GMM estimator outlined in Arellano \& Bond (1991). They use the first difference transform to expunge fixed effects, and use higher lags of the endogenous regressors as internal instruments. In unbalanced panels, however, this transform may cause large data loss and so the forward orthogonal deviations transformation of Arellano \& Bover (1995) is more commonly used. Furthermore, Blundell \& Bond (1998) find that if the regressand has high persistence (i.e. $\alpha$ has an absolute value close to 1) then difference GMM estimators perform poorly. This is because in the case of high persistence, the regressand behaves like a random walk and so past values are uninformative about future changes. Therefore, higher order lags of the regressors are weak instruments for the differenced variables (Roodman, 2009). The

${ }^{13} \operatorname{Gap}_{i, t}=\left(F D_{i, t}-F D_{i, t}^{B M}\right) / F D_{i, t}^{B M}$

where $F D$ is the level of an indicator of a specific dimension of financial development and $F D^{B M}$ is its benchmark level based on structural variables. We reverse the sign in the definition of the gap for efficiency and stability to facilitate the comparison of the influence of policies across the three dimensions. For details, see table 1 and section 6 .

${ }^{14}$ In our estimations, we use the following four structural variables: real GDP per capita, population size, population density, and age dependency ratio. For details, see table 1. 
preferred estimator in this case is the system GMM estimator developed by Arellano \& Bover (1995) and Blundell \& Bond (1998). In this case, instead of removing fixed effects through differencing (or forward orthogonalisation) of the regressors, the instruments - for instance, higher order lags of regressors - are instead differenced to make them exogenous to the fixed effects. These higher order differences now serve as internal instruments for the regressors.

Both difference and system GMM estimators employ moment conditions for the instruments used. These conditions are valid based on the assumption that the disturbances $v_{i, t}$ are truly independent; i.e. that they are serially uncorrelated. The Arellano-Bond test, therefore, checks for serial correlation in the residuals by testing the residuals in the differenced equations for serial correlation. Since the differenced residual $\Delta v_{i, t}=v_{i, t}-v_{i, t-1}$ is related to $\Delta v_{i, t-1}=v_{i, t-1}-\Delta v_{i, t-2}$ by definition, finding evidence of first-order serial correlation is to be expected. The key test is therefore to check for second-order serial correlation in the differenced residuals. One needs to be unable to reject the null hypothesis of no second-order serial correlation.

In addition, it is standard in GMM regressions to run the Sargan/Hansen test to check for the joint validity of the instruments. As Roodman (2009) notes, having too many instruments can over fit the endogenous variables and inadequately deal with the endogeneity, leading to an "excessively large" Hansen statistic. Using the rule of thumb in Roodman (2009), we limit the number of instruments to less than the number of countries in each of our regressions by restricting the number of lags in the GMM-style instruments, and by using the collapsing method of Holtz-Eakin, Newey, and Rosen (1988).

In our regressions, we run difference (with forward orthogonal deviations) and system GMM estimations to both specifications of our model, as appropriate, and include the standard diagnostic checks highlighted above. We run three separate formulations for each specification of the model treating policy variables as exogenous, predetermined, and endogenous, respectively. The lagged dependent variable is always treated as endogenous. In the first two formulations, wherein we assume the policy variables to be exogenous, and predetermined, we lag the policy variables by one period to make our assumptions less contentious. This ensures that we are immune to biases in our estimates caused by contemporaneous shocks to the regressand and the policy variables. In the second model specification when we include structural variables as controls, these variables are always treated as exogenous and therefore also lagged by one period. For all six of our runs, we also include pooled OLS and fixed effects estimations which, while technically incorrect, provide a useful check on our results particularly in regard to the coefficient of the lagged dependent variable.

\section{DAta, Measurement, AND SourCeS}

We compiled a data set spanning 180 countries and 28 years (1984-2011) using data from a number of different sources. The final panel was unbalanced and indicator coverage varied for the different dimensions of financial development. The final data set used for the analysis 
of banking sector depth consisted of 2396 observations across 115 countries between 1984 and 2011. For efficiency and stability, the coverage was from 1998-2011 and the data sets consisted of 1179 observations across 103 countries, and 930 observations across 85 countries, respectively.

The financial development indicators and benchmarks were obtained from the FinStats 2014 database compiled by the World Bank ${ }^{15}$. Private credit as a percentage of GDP was used as the indicator for depth, net interest margin as the indicator for efficiency, and non-performing loans as a percentage of total gross loans as the indicator for stability. From the list of theoretically appropriate candidates, the indicator representing each dimension was chosen based on the availability of benchmarks, the sample size, and breadth (countries) and depth (years) of coverage.

Macroeconomic data ${ }^{16}$ were obtained from the World Economic Outlook (WEO) data set at the IMF, the World Development Indicators (WDI) and Global Financial Development (GFDD) data set from the World Bank. The measure of trade openness was constructed as the ratio of real imports to real GDP. We feel that the frequently used definition of trade openness as the ratio of net exports to GDP may be misleading as it overstates the level of openness in the case of countries with large reserves of natural resources which are "forced" to export once domestic demand is met. The measure for financial openness was chosen to be the "de jure" measure constructed by Chinn \& Ito (2008). We use two measures of political and institutional quality in our analysis - the polity score as calculated by the Polity IV project and the average annual composite risk rating obtained from International Country Risk Guide (ICRG) — a monthly publication of the Political Risk Services (PRS). Detailed definitions of the variables used in our analyses are provided in Table 1, while Tables 2-7a provide summary statistics of data sets used in the analyses of the different dimensions of banking sector development.

\section{EMPIRICAL ANALYSIS}

\subsection{Estimation results}

The main results of this paper are presented in Tables $2-7 b$. Tables $2 b, 3 b$, and $4 b$ report the results of estimating Equation No. 1 using the development gaps for depth, efficiency, and stability, respectively, whereas Tables $5 \mathrm{~b}, 6 \mathrm{~b}$, and $7 \mathrm{~b}$ report the results of estimating Equation No. 2 using the indicators for banking sector depth, efficiency, and stability. In each of these tables we see that the p-values for the Arellano-Bond test for second order serial

\footnotetext{
${ }^{15}$ See Feyen et al (2013).

${ }^{16}$ Our dataset included a few of episodes of hyperinflation, e.g. Zaire in $1994(23,773 \%)$, Georgia in 1994 $(15,606 \%)$, and Nicaragua in $1987(13,109 \%)$. These outliers were exponentially larger than the majority of the inflation data series and grossly skewed results forcing us to drop these observations (top 1\% values) from our dataset.
} 
correlation $(\mathrm{AR}(2))$ is sufficiently high. The p-values for the Hansen tests confirm that the instruments are appropriate in each case. In each of our regressions, we find that lags ${ }^{17}$ of the $y$-variable are significant, validating the choice of a dynamic specification. Finally, comparing the results from the gap analysis - for instance, those fitting Equation No.1—with those from the second specification, we find that the policy determinants of the different dimensions, as determined by either specification, are largely similar. While a few determinants lose significance when switching from Model No. 1 to Model No. 2, we do not observe a reversal in sign for any of the variables.

Tables $2 \mathrm{~b}$ and $5 \mathrm{~b}$ examine the policy determinants of financial depth. Our indicator for financial depth is the amount of private credit extended as a fraction of GDP. The higher this indicator is, the greater the depth of the financial sector. Further, given the definition of the financial depth gap ${ }^{18}$, a positive gap implies that the financial sector is over-performing with regards to depth. Therefore, in both tables, variables with positive coefficients can be thought of as positively influencing financial depth. Firstly, we find that financial depth (and the depth gap) exhibits a very high level of persistence. We therefore focus more on the results of system GMM estimations. Our results show that growth, banking crises, trade openness, and the quality of institutions (as measured by the composite risk rating) influence financial depth. The positive effect of the growth rate on financial depth is significant when we treat it as (lagged) exogenous and (lagged) predetermined, but it loses significance when endogenised. The occurrence of banking crises significantly reduces financial depth, as expected. Increasing trade openness in an economy also seems to positively influence financial depth, as does having better institutions.

The policy determinants of financial efficiency are assessed in Tables $3 \mathrm{~b}$ and $6 \mathrm{~b}$. The indicator for financial efficiency is the net interest margin in the banking sector. As opposed to depth, greater efficiency would mean we observe a lower level of this indicator. In our definition of efficiency gap, we reverse the sign so as to facilitate comparison of the influence of policies across all three dimensions. Therefore, a variable that positively influences financial efficiency would have a positive coefficient in Table $3 b$ and a negative coefficient in Table 6b. Our results show that higher inflation seems to be detrimental to financial efficiency — which seems intuitive - as a more stable macroeconomic environment would promote the cost effectiveness of the financial system. As per the results of Table $3 \mathrm{~b}$, banking crises seem to have a positive effect on efficiency, though this loses significance in the alternate specification in Table $6 \mathrm{~b}$. This could be explained by the purging effect of crises wherein weaker, inefficient banks are wiped out by a crisis and overall efficiency may end up being improved. The results also seem to suggest that stronger institutions also promote efficiency, though the significance of this relationship is lower. Interestingly, we find that the Lerner index of the competitiveness of the banking sector is insignificant in the gap analysis but is significant in the second model specification. The relationship is as expected with greater competitiveness spurring an increase in efficiency.

\footnotetext{
${ }^{17}$ In the case of financial depth, we needed to add second order lags to obtain satisfactory results.

${ }^{18}$ See Table 1 for detailed definitions of all the variables used in our analyses.
} 
Finally, Tables $4 \mathrm{~b}$ and $7 \mathrm{~b}$ look at the policy determinants of financial stability. The indicator for this dimension is the fraction of total loans considered non-performing. As in the case of efficiency, a more stable financial system would have a lower value of this indicator ${ }^{19}$. Therefore, we reverse the sign in the definition of the stability gap as well. A policy variable seen to positively influence financial stability would, therefore, have a positive coefficient in Table $4 \mathrm{~b}$ and a negative coefficient in Table $7 b^{20}$. Our regressions show that the key policy determinants of financial stability are growth, banking crises, inflation, and, to a lesser extent, institutions. The positive effect of growth on stability is extremely significant and persists through all specifications. Higher growth would imply an increase in real returns on projects and an increased capacity to repay loans, reducing the amount of non-performing loans. The results in Table $4 \mathrm{~b}$ would suggest that an increase in inflation might aid financial stability but this effect all but disappears in the results of the second model specification in Table $7 \mathrm{~b}$. The effect might be explained by the fact that inflation reduces the real rate of interest on loans, thereby easing the debt burden. As expected, banking crises are shown to reduce financial stability, though this result also loses significance in the second model specification. Finally, the quality of institutions is yet again a significant factor as an increase in the risk rating is shown to increase financial stability.

\subsection{Robustness checks}

We test the robustness of the results of our analyses by re-running them under three separate limiting situations. For our first robustness check, we trim the sample to low and middle income countries by excluding all data from high income countries - both within and outside the OECD. Our second robustness check limits the data sample to the period before the global financial crisis (i.e. up to 2007). Our final robustness check tests the impact of outliers in the regressand on our results. To this end, we repeat the analysis on the middle $95 \%$ of the regressand values; i.e. we trim out the top and bottom $2.5 \%$ values of the y-variable for each of our regressions. The results of our robustness checks are presented in Tables 2-7c.

In the case of financial depth, we find that most of our results are resilient to the robustness checks. While trimming the sample to developing countries significantly reduces the breadth of the sample, most of the effects observed in the full sample still persist. Growth still plays an important, positive role in increasing financial depth, while institutions become even more important. The level of democracy (polity score) becomes a significant positive factor in some of the specifications for the developing country sample. Remittances seem to have a negative effect on financial depth in our robustness checks, but this effect disappears in the

\footnotetext{
${ }^{19}$ A number of studies (Shubik \& Wilson, 1977, Dubey et al, 2005) have studied default in a general equilibrium setting and discuss the notion of the optimal level of default in an economy. Their discussion would suggest that lowering the fraction of non-performing in an economy to zero is in fact welfare reducing. Such arguments further highlight the usefulness of the frontier analysis to guide policy. Working towards a constrained optimal level of financial stability would be more appropriate than trying to increase the level of stability outright.

${ }^{20}$ In order to obtain statistically satisfactory results we had to use second lags of inflation, remittances, trade openness, and the composite risk rating when treating them as predetermined.
} 
second model specification. The pre-crisis sample and trimmed sample show the same general results with growth, banking crises, and institutional quality being the most significant of the explanatory variables.

The robustness checks for financial efficiency also provide validation for the previously reported results. The negative impact of high inflation on financial efficiency holds through most of the robustness checks. Institutions still seem to play a role, though this is not the case for the developing countries' sample. The coefficient of the banking crisis dummy variable loses significance, and this is not altogether surprising. Finally, the measure of competitiveness remains significant through most specifications and seems particularly significant in developing countries.

The impact of reduced sample sizes in the robustness checks is most severe for the indicator of financial stability. When the analysis is limited to developing countries, the sample width is almost halved. The results of this are quite severe, with only growth and banking crises retaining some explanatory power in developing countries. Our results do better in the trimmed sample and we find that growth, inflation, banking crises, and institutional quality are significant determinants of financial stability.

\section{Conclusions}

This paper sought to determine the key policy determinants of financial development as measured across three dimensions: depth, efficiency, and stability. To this end, we employed the financial possibility frontier framework which splits the determinants of financial development into two categories: structural fundamentals, and policy and institutional factors. This framework was operationalized by benchmarking economies based on their structural fundamentals. Analyzing the gap between the actual values of indicators of financial development and their values predicted by structural benchmarks, we identified the policy determinants of the different dimensions of financial development. We ran an alternate model specification and a battery of robustness checks to thoroughly vet our results. Table 8 summarizes the impact of the different policy and institutional variables applied to the three dimensions of financial development studied.

The financial possibility frontier is an intuitively appealing framework to assess the suitability of policy measures targeting financial development. Knowing where a country stands relative to its structural benchmark would point to an appropriate set of policy tools, be they market-enabling, market-developing, or market-harnessing. Moreover, such analysis must be extended to all dimensions of financial development to offer a more fine-tuned diagnosis of a country's financial development. Finally, identifying the effect of individual policy variables on these different dimensions enables us to design the appropriate policy mix to address the needs of an economy.

In conclusion, we reiterate that the main purpose of this study is to identify the policy determinants of financial development across three main dimensions: depth, efficiency, and stability. We do not explicitly consider the political economy of financial development and 
financial policy, ${ }^{21}$ instead treating policy variables as exogenous in the sense that governments may enforce them in an unconstrained manner to influence financial development along these three dimensions. ${ }^{22}$ Finally, it must be stressed, once again, that even though our analysis is carried out on a broad sample of countries using relatively long time series, our results are meant to guide intuition in country-specific policy analyses, rather than to prescribe global solutions for local maladies.

\footnotetext{
${ }^{21}$ See Girma \& Shortland (2007), Haber \& Perotti (2008), and Benmelech \& Moskowitz (2010) for discussions on the political economy of financial development.

${ }^{22}$ While some of the variables included in our analyses - trade and financial openness, and polity score, act as simplistic indicators of the strength of the political influence of domestic incumbents, as theorised by Rajan \& Zingales (2003), and of the transparency and accountability of policy makers, we do not explicitly consider the political calculus of financial policy and reform.
} 


\begin{tabular}{|c|c|c|c|}
\hline Variable & Definition & $\begin{array}{l}\text { Unit of } \\
\text { measurement }\end{array}$ & Source \\
\hline \multicolumn{4}{|c|}{ Financial Development Indicators } \\
\hline Private Credit & $\begin{array}{l}\text { Domestic private credit to the real sector by deposit money banks to GDP. Data obtained from IMF } \\
\text { International Financial Statistics. }\end{array}$ & $\%$ of GDP & FinStats \\
\hline Net Interest Margin & $\begin{array}{l}\text { Accounting value of banks' net interest revenue as a share of its average interest-bearing (total } \\
\text { earning) assets. Net Interest Revenue (or Income) = Gross interest and dividend income - Total } \\
\text { interest expense. Total Earning Assets = Total loans + Total Securities + Investments in property + } \\
\text { Other earning assets. Data obtained from Bankscope }\end{array}$ & $\%$ & FinStats \\
\hline Non Performing Loans & $\begin{array}{l}\text { Non-performing loans to total gross loans. Data obtained from the IMF Global Financial Stability } \\
\text { Report. }\end{array}$ & $\begin{array}{l}\% \text { of Total } \\
\text { Gross Loans }\end{array}$ & FinStats \\
\hline Depth Gap & $\begin{array}{l}\text { Defined as the difference between actual value of private credit/GDP and the predicted benchmark } \\
\text { value divided by the benchmark. Benchmarks are calculated using median regressions of indicators } \\
\text { on structural variables (GDP/capita, its square, population, population density, age dependency } \\
\text { ratios - old and young, dummies for fuel exporters, transition countries and offshore financial } \\
\text { centers, and time dummies), across a large panel. } \\
\text { Gap }_{\text {it }}=\left(\text { Level }_{\text {it }}-\text { Benchmark }_{\text {it }} \text { /Benchmark }\right. \\
\text { it }\end{array}$ & $\begin{array}{l}\text { relative } \\
\text { deviation from } \\
\text { benchmark }\end{array}$ & FinStats \\
\hline Efficiency Gap & $\begin{array}{l}\text { Defined as the difference between the predicted benchmark value and the actual value of net } \\
\text { interest margin and the benchmark value divided by the benchmark. Note the reversal in sign. } \\
\text { Gap }_{\text {it }}=\left(\text { Benchmark }_{i t}-\text { Level }_{i t}\right) / \text { Benchmark }_{i t}\end{array}$ & $\begin{array}{l}\text { relative } \\
\text { deviation from } \\
\text { benchmark }\end{array}$ & FinStats \\
\hline Stability Gap & $\begin{array}{l}\text { Defined as the difference between the benchmark value and the indicator value of NPL/total gross } \\
\text { loans and the benchmark value divided by the benchmark. Note the reversal in sign. } \\
\text { Gap }_{\text {it }}=\left(\text { Benchmark }_{i t}-\text { Level }_{i t}\right) / \text { Benchmark }_{i t}\end{array}$ & $\begin{array}{l}\text { relative } \\
\text { deviation from } \\
\text { benchmark }\end{array}$ & FinStats \\
\hline \multicolumn{4}{|l|}{ Macroeconomic Variables } \\
\hline Growth Rate & $\begin{array}{l}\text { Annual percentage growth rate of GDP per capita based on constant local currency. Aggregates are } \\
\text { based on constant } 2005 \text { U.S. dollars. GDP per capita is gross domestic product divided by midyear } \\
\text { population. }\end{array}$ & $\begin{array}{l}\% \text { change in } \\
\text { real GDP }\end{array}$ & WDI \\
\hline Inflation & Annual percentage change in consumer prices & $\begin{array}{l}\text { \% change in } \\
\text { CPI }\end{array}$ & WEO \\
\hline Remittance Inflows & $\begin{array}{l}\text { Workers' remittances and compensation of employees comprise current transfers by migrant } \\
\text { workers and wages and salaries earned by nonresident workers. Data are the sum of three items } \\
\text { defined in the fifth edition of the IMF's Balance of Payments Manual: workers' remittances, } \\
\text { compensation of employees, and migrants' transfers. }\end{array}$ & $\%$ of GDP & GFDD \\
\hline Banking Crisis & $\begin{array}{l}\text { Dummy variable for the presence of banking crisis (1=banking crisis, } 0=\text { none). Obtained from - Luc } \\
\text { Laeven and Fabián Valencia, 2012. "Systemic Banking Crises Database: An Update", IMF Working } \\
\text { Paper WP/12/163 }\end{array}$ & $\begin{array}{l}\text { Dummy } \\
\text { variable }\end{array}$ & GFDD \\
\hline \multicolumn{4}{|l|}{ Openness Variables } \\
\hline Financial Openness & $\begin{array}{l}\text { A "de jure" measure of financial openness calculated as the first principal component of four binary } \\
\text { dummy variables that codify restrictions on cross-border financial transactions reported in the IMF's } \\
\text { Annual Report on Exchange Arrangements and Exchange Restrictions. }\end{array}$ & $\begin{array}{l}\text { Chinn - Ito } \\
\text { Index }\end{array}$ & $\begin{array}{r}\text { Chinn-Ito } \\
\text { (2008) }\end{array}$ \\
\hline & Calculated as the ratio of real imports to real GDP. & $\%$ of GDP & WEO \\
\hline \multicolumn{4}{|l|}{ Institutional Variables } \\
\hline Polity Score & $\begin{array}{l}\text { A codified measure of a country's political regime based on (Jaggers and Gurr 1995; Marshall and } \\
\text { Jaggers 2002). Scores can range from -10 to } 10 \text {, with } 10 \text { representing a full democracy. }\end{array}$ & $\begin{array}{l}\text { Polity Index, } \\
10 \text { to } 10\end{array}$ & $\begin{array}{r}\text { Polity IV } \\
\text { Project }\end{array}$ \\
\hline Composite Risk Rating & $\begin{array}{l}\text { The International Country Risk Guide (ICRG) rating comprises } 22 \text { variables in three subcategories of } \\
\text { risk: political, financial, and economic. A separate index is created for each of the subcategories. The } \\
\text { Political Risk index is based on } 100 \text { points, Financial Risk on } 50 \text { points, and Economic Risk on } 50 \\
\text { points. The total points from the three indices are divided by two to produce the weights for } \\
\text { inclusion in the composite country risk score. The composite scores therefore ranging from zero to } \\
100 \text { with a higher score implying lower risk. }\end{array}$ & $\begin{array}{l}\text { Risk Score, } 0 \text { to } \\
100\end{array}$ & ICRG \\
\hline \multicolumn{4}{|l|}{ Market Power } \\
\hline Lerner Index & $\begin{array}{l}\text { A measure of market power in the banking market. It compares output pricing and marginal costs } \\
\text { (that is, markup). An increase in the Lerner index indicates a deterioration of the competitive conduct } \\
\text { of financial intermediaries. }\end{array}$ & Lerner Index & GFDD \\
\hline \multicolumn{4}{|l|}{ Structural Variables } \\
\hline$\overline{\text { Real GDP per capita }}$ & $\begin{array}{l}\text { GDP per capita is gross domestic product divided by midyear population. GDP is the sum of gross } \\
\text { value added by all resident producers in the economy plus any product taxes and minus any subsidies } \\
\text { not included in the value of the products. }\end{array}$ & $\begin{array}{l}\text { Thousands of } \\
\text { (constant } \\
2005 \text { ) US\$ }\end{array}$ & WDI \\
\hline Population & $\begin{array}{l}\text { Total population is based on the de facto definition of population, which counts all residents } \\
\text { regardless of legal status or citizenship--except for refugees not permanently settled in the country of } \\
\text { asylum, who are generally considered part of the population of their country of origin. The values } \\
\text { shown are midyear estimates. }\end{array}$ & $\begin{array}{l}\text { Tens of } \\
\text { millions }\end{array}$ & WDI \\
\hline Population Density & $\begin{array}{l}\text { Population density is midyear population divided by land area in square kilometers. Population is } \\
\text { based on the de facto definition of population, while land area is a country's total area, excluding } \\
\text { area under inland water bodies, national claims to continental shelf, and exclusive economic zones. }\end{array}$ & $\begin{array}{l}\text { People per sq. } \\
\mathrm{km} \text { of land } \\
\text { area }\end{array}$ & WDI \\
\hline Age Dependency Ratio & $\begin{array}{l}\text { Obtained by adding the old and young age dependency ratios. It is therefore is the ratio of } \\
\text { dependents--people younger than } 15 \text { or older than } 64 \text {--to the working-age population--those ages } 15 \text { - } \\
64 \text {. }\end{array}$ & $\begin{array}{l}\% \text { of working- } \\
\text { - age population }\end{array}$ & WDI \\
\hline
\end{tabular}


Table 2a. Summary Statistics and Correlations: Banking Sector Depth (gap analysis), Global Sample, Annual Data (2,382 observations, 115 countries)

\begin{tabular}{|c|c|c|c|c|c|c|c|c|c|c|c|c|c|c|c|}
\hline & & & Abbreviation & & Source & & Unit of me & rement & & Mean & $\begin{array}{r}\text { Overall } \\
\text { Standard } \\
\text { Deviation }\end{array}$ & $\begin{array}{c}\text { Between } \\
\text { Standard } \\
\text { Deviation }\end{array}$ & $\begin{array}{r}\text { Within } \\
\text { Standard } \\
\text { Deviation }\end{array}$ & Maximum & Minimum \\
\hline \multicolumn{3}{|c|}{ Depth Gap (Private Credit) } & \multicolumn{2}{|l|}{ PC_gap } & \multicolumn{2}{|l|}{ FinStats } & \multicolumn{3}{|c|}{ relative deviation from benchmark } & 0.08 & 0.67 & 0.57 & 0.39 & 3.78 & -0.98 \\
\hline \multirow{2}{*}{\multicolumn{2}{|c|}{$\begin{array}{l}\text { Growth Rate } \\
\text { Inflation }\end{array}$}} & & \multicolumn{2}{|l|}{ Growth } & \multicolumn{2}{|l|}{ WDI } & \multicolumn{3}{|c|}{$\%$ change in real GDP } & 2.26 & 4.07 & 1.95 & 3.64 & 30.34 & -29.67 \\
\hline & & & $\operatorname{lnf}$ & & \multirow{2}{*}{\multicolumn{2}{|c|}{$\begin{array}{l}\text { WEO } \\
\text { GFDD }\end{array}$}} & \multicolumn{3}{|c|}{ \% change in CPI } & 9.94 & 15.44 & 8.66 & 12.68 & 178.70 & -8.24 \\
\hline \multicolumn{3}{|c|}{ Remittance Inflows } & \multicolumn{2}{|l|}{$\begin{array}{l}\text { Inf } \\
\text { Rem }\end{array}$} & & & $\%$ of GDP & & & 2.63 & 4.33 & 4.47 & 1.91 & 34.50 & 0.00 \\
\hline \multirow{2}{*}{\multicolumn{3}{|c|}{$\begin{array}{l}\text { Banking Crisis } \\
\text { Financial Openness }\end{array}$}} & \multicolumn{2}{|l|}{ Crisis } & \multicolumn{2}{|l|}{ GFDD } & \multicolumn{3}{|c|}{ Dummy variable } & 0.11 & 0.31 & 0.11 & 0.30 & 1 & 0 \\
\hline & & & FO & & \multirow{2}{*}{\multicolumn{2}{|c|}{$\begin{array}{l}\text { Chinn \& Ito (2006) } \\
\text { WEO }\end{array}$}} & \multicolumn{3}{|c|}{ Chinn - Ito Index } & 0.31 & 1.57 & 1.39 & 0.83 & 2.44 & -1.86 \\
\hline \multicolumn{3}{|c|}{ Trade Openness } & \multicolumn{2}{|l|}{ TO } & & & $\%$ of GDP & & & 37.62 & 22.29 & 22.11 & 10.56 & 274.39 & 1.94 \\
\hline \multirow{2}{*}{\multicolumn{3}{|c|}{$\begin{array}{l}\text { Polity Score } \\
\text { Composite Risk Rating }\end{array}$}} & \multirow{2}{*}{\multicolumn{2}{|c|}{$\begin{array}{l}\text { Pol } \\
\text { Risk }\end{array}$}} & Polity IV Pro & & Polity Inde & 10 to 10 & & 4.46 & 6.15 & 5.85 & 2.81 & 10 & -10 \\
\hline & & & & & ICRG & & Risk Score, & o 100 & & 67.63 & 11.60 & 9.68 & 6.16 & 92.38 & 28.29 \\
\hline Correlatio & natrix & & & & & & & & & & & & & & \\
\hline & PC_gap & Growth & $\operatorname{lnf}$ & Rem & Crisis & FO & TO & Pol & Risk & & & & & & \\
\hline PC_gap & 1.0000 & & & & & & & & & & & & & & \\
\hline Growth & 0.0195 & 1.0000 & & & & & & & & & & & & & \\
\hline Inf & -0.2092 & -0.0808 & 1.0000 & & & & & & & & & & & & \\
\hline Rem & 0.1278 & 0.0623 & -0.0279 & 1.0000 & & & & & & & & & & & \\
\hline Crisis & 0.0534 & -0.2235 & 0.1171 & -0.0775 & 1.0000 & & & & & & & & & & \\
\hline FO & 0.0237 & 0.0377 & -0.2929 & 0.0038 & 0.0100 & 1.0000 & & & & & & & & & \\
\hline TO & 0.2274 & 0.1066 & -0.1602 & 0.4391 & -0.0092 & 0.1295 & 1.0000 & & & & & & & & \\
\hline Pol & -0.1474 & 0.0675 & -0.1281 & -0.0826 & 0.0086 & 0.4267 & 0.0655 & 1.0000 & & & & & & & \\
\hline Risk & 0.1033 & 0.1958 & -0.3815 & -0.1824 & -0.0656 & 0.5866 & 0.0624 & 0.4714 & 1.0000 & & & & & & \\
\hline
\end{tabular}


Table 2b. Determinants of Banking Sector Depth (gap analysis)

\begin{tabular}{|c|c|c|c|c|c|c|c|c|}
\hline \multirow[b]{2}{*}{ Variables } & \multirow[b]{2}{*}{ OLS } & \multirow[b]{2}{*}{$\mathrm{FE}$} & \multicolumn{2}{|c|}{ Exogenous } & \multicolumn{2}{|c|}{ Predetermined } & \multicolumn{2}{|c|}{ Endogenous } \\
\hline & & & D GMM & S GMM & D GMM & S GMM & D GMM & S GMM \\
\hline \multicolumn{9}{|l|}{ Lags } \\
\hline Depth Gap (t - 1) & $\begin{array}{c}1.1276^{* * *} \\
(0.0189)\end{array}$ & $\begin{array}{c}1.0439 * * * \\
(0.0193)\end{array}$ & $\begin{array}{c}1.1089 * * * \\
(0.0764)\end{array}$ & $\begin{array}{c}1.1050^{* * *} \\
(0.0623)\end{array}$ & $\begin{array}{c}1.0746 * * * \\
(0.0741)\end{array}$ & $\begin{array}{c}1.0945^{* * *} \\
(0.0625)\end{array}$ & $\begin{array}{c}1.1298^{* * *} \\
(0.0551)\end{array}$ & $\begin{array}{c}1.1283 * * * \\
(0.0437)\end{array}$ \\
\hline Depth Gap (t - 2) & $\begin{array}{c}-0.1778^{* * *} \\
(0.0187)\end{array}$ & $\begin{array}{c}-0.1672^{* * *} \\
(0.0190)\end{array}$ & $\begin{array}{l}-0.1200^{*} \\
(0.0654)\end{array}$ & $\begin{array}{c}-0.1310^{* *} \\
(0.0570)\end{array}$ & $\begin{array}{l}-0.1035 \\
(0.0637)\end{array}$ & $\begin{array}{c}-0.1435 * * * \\
(0.0532)\end{array}$ & $\begin{array}{c}-0.1466 * * * \\
(0.0388)\end{array}$ & $\begin{array}{c}-0.1650 * * * \\
(0.0366)\end{array}$ \\
\hline \multicolumn{9}{|l|}{ Policy variables } \\
\hline Growth & $\begin{array}{c}-0.0019 * * \\
(0.0009)\end{array}$ & $\begin{array}{c}-0.0061 * * * \\
(0.0010)\end{array}$ & $\begin{array}{c}0.0084 * * * \\
(0.0017)\end{array}$ & $\begin{array}{c}0.0081^{* * *} \\
(0.0016)\end{array}$ & $\begin{array}{c}0.0094^{* * *} \\
(0.0020)\end{array}$ & $\begin{array}{c}0.0079 * * * \\
(0.0019)\end{array}$ & $\begin{array}{c}0.0021 \\
(0.0048)\end{array}$ & $\begin{array}{c}0.0024 \\
(0.0056)\end{array}$ \\
\hline Inflation & $\begin{array}{c}-0.0010^{* * *} \\
(0.0002)\end{array}$ & $\begin{array}{c}-0.0014^{* * *} \\
(0.0003)\end{array}$ & $\begin{array}{l}-0.0011 \\
(0.0009)\end{array}$ & $\begin{array}{l}-0.0010 \\
(0.0007)\end{array}$ & $\begin{array}{c}-0.0009 \\
(0.0008)\end{array}$ & $\begin{array}{l}-0.0012 \\
(0.0008)\end{array}$ & $\begin{array}{c}-0.0008 \\
(0.0007)\end{array}$ & $\begin{array}{l}-0.0007 \\
(0.0007)\end{array}$ \\
\hline Remittance Inflows & $\begin{array}{l}-0.0007 \\
(0.0009)\end{array}$ & $\begin{array}{c}-0.0032^{*} \\
(0.0018)\end{array}$ & $\begin{array}{l}-0.0025 \\
(0.0022)\end{array}$ & $\begin{array}{l}-0.0010 \\
(0.0009)\end{array}$ & $\begin{array}{l}-0.0049 \\
(0.0055)\end{array}$ & $\begin{array}{c}0.0048 \\
(0.0068)\end{array}$ & $\begin{array}{l}-0.0054 \\
(0.0053)\end{array}$ & $\begin{array}{c}0.0063 \\
(0.0082)\end{array}$ \\
\hline Banking Crisis Dummy & $\begin{array}{c}-0.0762^{* * *} \\
(0.0112)\end{array}$ & $\begin{array}{c}-0.0530 * * * \\
(0.0122)\end{array}$ & $\begin{array}{c}-0.0860^{* * *} \\
(0.0181)\end{array}$ & $\begin{array}{c}-0.0794 * * * \\
(0.0163)\end{array}$ & $\begin{array}{c}-0.0943 * * * \\
(0.0273)\end{array}$ & $\begin{array}{c}-0.0567^{* * *} \\
(0.0189)\end{array}$ & $\begin{array}{c}-0.0930 * * * \\
(0.0314)\end{array}$ & $\begin{array}{c}-0.0706 * * * \\
(0.0214)\end{array}$ \\
\hline \multicolumn{9}{|l|}{ Openness variables } \\
\hline Financial Openness & $\begin{array}{c}-0.0055^{* *} \\
(0.0027)\end{array}$ & $\begin{array}{c}-0.0015 \\
(0.0044)\end{array}$ & $\begin{array}{c}-0.0019 \\
(0.0060)\end{array}$ & $\begin{array}{c}-0.0003 \\
(0.0033)\end{array}$ & $\begin{array}{c}-0.0358^{* *} \\
(0.0171)\end{array}$ & $\begin{array}{l}-0.0007 \\
(0.0068)\end{array}$ & $\begin{array}{c}-0.0290 * * \\
(0.0146)\end{array}$ & $\begin{array}{l}-0.0014 \\
(0.0071)\end{array}$ \\
\hline Trade Openness & $\begin{array}{c}0.0008^{* * *} \\
(0.0002)\end{array}$ & $\begin{array}{c}0.0016 * * * \\
(0.0004)\end{array}$ & $\begin{array}{c}0.0006 \\
(0.0004)\end{array}$ & $\begin{array}{c}0.0004^{* *} \\
(0.0002)\end{array}$ & $\begin{array}{c}0.0032 * * \\
(0.0013)\end{array}$ & $\begin{array}{c}0.0009 \\
(0.0005)\end{array}$ & $\begin{array}{c}-0.0000 \\
(0.0013)\end{array}$ & $\begin{array}{l}0.0011^{*} \\
(0.0006)\end{array}$ \\
\hline \multicolumn{9}{|l|}{ Institutional variables } \\
\hline Polity Score & $\begin{array}{l}-0.0004 \\
(0.0006)\end{array}$ & $\begin{array}{c}-0.0027^{* *} \\
(0.0013)\end{array}$ & $\begin{array}{l}-0.0004 \\
(0.0014)\end{array}$ & $\begin{array}{c}0.0005 \\
(0.0008)\end{array}$ & $\begin{array}{c}-0.0094^{* *} \\
(0.0040)\end{array}$ & $\begin{array}{l}-0.0023 \\
(0.0024)\end{array}$ & $\begin{array}{c}-0.0105^{* * *} \\
(0.0040)\end{array}$ & $\begin{array}{l}-0.0024 \\
(0.0024)\end{array}$ \\
\hline Composite Risk Rating & $\begin{array}{c}0.0012^{* * *} \\
(0.0004)\end{array}$ & $\begin{array}{c}0.0047^{* * *} \\
(0.0007)\end{array}$ & $\begin{array}{c}0.0010 \\
(0.0009)\end{array}$ & $\begin{array}{c}0.0000 \\
(0.0006)\end{array}$ & $\begin{array}{c}0.0040^{* *} \\
(0.0017)\end{array}$ & $\begin{array}{c}0.0012 \\
(0.0013)\end{array}$ & $\begin{array}{c}0.0070^{* * *} \\
(0.0020)\end{array}$ & $\begin{array}{l}0.0023 * \\
(0.0013)\end{array}$ \\
\hline Constant & $\begin{array}{c}-0.0915^{* * *} * \\
(0.0355) \\
\end{array}$ & $\begin{array}{c}-0.2927 * * * \\
(0.0511)\end{array}$ & & $\begin{array}{c}0.0443 \\
(0.0437) \\
\end{array}$ & & $\begin{array}{c}-0.0461 \\
(0.0782) \\
\end{array}$ & & $\begin{array}{c}-0.1755^{* *} \\
(0.0785) \\
\end{array}$ \\
\hline Observations & 2,382 & 2,382 & 2,266 & 2,381 & 2,266 & 2,381 & 2,267 & 2,382 \\
\hline R-squared & 0.9444 & 0.8497 & & & & & & \\
\hline Time Dummies & YES & YES & YES & YES & YES & YES & YES & YES \\
\hline Number of countries & & 115 & 114 & 115 & 114 & 115 & 113 & 115 \\
\hline Number of instruments & & & 66 & 69 & 100 & 111 & 100 & 111 \\
\hline Hansen Test & & & 0.109 & 0.0745 & 0.452 & 0.149 & 0.207 & 0.235 \\
\hline$A R(1)$ & & & $1.61 \mathrm{e}-06$ & $2.86 \mathrm{e}-07$ & $8.85 e-07$ & $1.84 \mathrm{e}-07$ & $2.10 \mathrm{e}-09$ & $1.30 \mathrm{e}-09$ \\
\hline$A R(2)$ & & & 0.718 & 0.798 & 0.589 & 0.870 & 0.597 & 0.461 \\
\hline
\end{tabular}

Standard errors in parentheses

*** $\mathrm{p}<0.01, * * \mathrm{p}<0.05, * \mathrm{p}<0.1$ 
Table 2c. Robustness Checks: Determinants of Banking Sector Depth (gap analysis)

\begin{tabular}{|c|c|c|c|c|c|c|c|c|c|c|c|c|c|c|c|c|c|c|}
\hline \multirow[b]{3}{*}{ Variables } & \multicolumn{6}{|c|}{ Developing Countries } & \multicolumn{6}{|c|}{ Pre-GFC (upto 2007) } & \multicolumn{6}{|c|}{ Trimmed Sample } \\
\hline & \multicolumn{2}{|c|}{ Exogenous } & \multicolumn{2}{|c|}{ Predetermined } & \multicolumn{2}{|c|}{ Endogenous } & \multicolumn{2}{|c|}{ Exogenous } & \multicolumn{2}{|c|}{ Predetermined } & \multicolumn{2}{|c|}{ Endogenous } & \multicolumn{2}{|c|}{ Exogenous } & \multicolumn{2}{|c|}{ Predetermined } & \multicolumn{2}{|c|}{ Endogenous } \\
\hline & DGMM & SGMM & D GMM & S GMM & DGMM & SGMM & D GMM & S GMM & D GMM & SGMM & DGMM & SGMM & DGMM & SGMM & DGMM & SGMM & DGMM & SGMM \\
\hline \multicolumn{19}{|l|}{ Lags } \\
\hline Depth Gap (t - 1) & $\begin{array}{c}1.0790^{* * *} \\
(0.0861)\end{array}$ & $\begin{array}{c}1.0719 * * * \\
(0.0719)\end{array}$ & $\begin{array}{c}1.0111^{* * *} \\
(0.0839)\end{array}$ & $\begin{array}{c}1.0358^{* * *} \\
(0.0689)\end{array}$ & \begin{tabular}{|c|}
$1.0674^{* * *}$ \\
$(0.0679)$
\end{tabular} & $\begin{array}{c}1.0831 * * * \\
(0.0494)\end{array}$ & $\begin{array}{c}1.0993^{* * *} \\
(0.1107)\end{array}$ & $\begin{array}{c}1.1188^{* * *} \\
(0.0769)\end{array}$ & $\begin{array}{c}1.0602^{* * *} \\
(0.0950)\end{array}$ & $\begin{array}{c}1.0791 * * * \\
(0.0772)\end{array}$ & $\begin{array}{c}1.0922^{* * *} \\
(0.0617)\end{array}$ & $\begin{array}{c}1.1319 * * * \\
(0.0511)\end{array}$ & $\begin{array}{c}1.0609 * * * \\
(0.0535)\end{array}$ & $\begin{array}{c}1.1081^{* * *} \\
(0.0432)\end{array}$ & $\begin{array}{c}1.0191 * * * \\
(0.0514)\end{array}$ & $\begin{array}{c}1.0956^{* * *} \\
(0.0397)\end{array}$ & $1.0291^{* * *}$ & $\begin{array}{l}1.1011^{* * *} \\
102^{3077}\end{array}$ \\
\hline Depth Gap (t - 2) & $\begin{array}{l}-0.0964 \\
(0.0725)\end{array}$ & $\begin{array}{l}-0.1071^{*} \\
(0.0631)\end{array}$ & $\begin{array}{l}-0.0786 \\
(0.0706)\end{array}$ & $\begin{array}{c}-0.1015^{*} \\
(0.0583)\end{array}$ & $\begin{array}{c}0.0111 \\
(0.0121)\end{array}$ & $\begin{array}{l}0.0014 \\
(0.0109)\end{array}$ & $\begin{array}{l}-0.0698 \\
(0.0831)\end{array}$ & $\begin{array}{l}-0.1044 \\
(0.0679)\end{array}$ & $\begin{array}{l}-0.0666 \\
(0.0763)\end{array}$ & $\begin{array}{l}-0.1005 \\
(0.0661)\end{array}$ & $\begin{array}{l}-0.0033 \\
(0.0058)\end{array}$ & $\begin{array}{l}0.0048 \\
(0.0061)\end{array}$ & $\begin{array}{c}-0.1216 * * * \\
(0.0363)\end{array}$ & $\begin{array}{l}-0.1361 * * * \\
-0.0345)\end{array}$ & $\begin{array}{l}-0.1215 * * * \\
(0.03411\end{array}$ & $\begin{array}{c}-0.1435 * * * \\
(0.0340)\end{array}$ & $\begin{array}{l}-0.0005 \\
10.046)\end{array}$ & $\begin{array}{l}0.0025 \\
0.0252\end{array}$ \\
\hline \multirow{2}{*}{\multicolumn{19}{|c|}{$\begin{array}{l}\text { Policy variables } \\
\text { Macroeconomic variables }\end{array}$}} \\
\hline & & & & & & & & & & & & & & & & & & \\
\hline Growth & $\begin{array}{c}0.0093^{* * *} \\
(0.0020)\end{array}$ & $\begin{array}{c}0.0090^{* * *} \\
(0.0019)\end{array}$ & \begin{tabular}{|c}
$0.0095 * * *$ \\
$(0.0023)$
\end{tabular} & $\begin{array}{c}0.0083 * * \\
(0.0022)\end{array}$ & $\begin{array}{l}-0.0009 \\
(0.0009)\end{array}$ & $\begin{array}{l}-0.0008 \\
(0.0009)\end{array}$ & $\begin{array}{c}0.0101 * * * \\
(0.0022)\end{array}$ & $\begin{array}{c}0.0099 * * * \\
(0.0019)\end{array}$ & $\begin{array}{c}0.0092^{* * *} \\
(0.0023)\end{array}$ & $\begin{array}{c}0.0088^{* * *} \\
(0.0024)\end{array}$ & $\begin{array}{l}-0.0007 \\
(0.0007)\end{array}$ & $\begin{array}{l}-0.0007 \\
(0.0007)\end{array}$ & $\begin{array}{c}0.0054^{* * *} \\
(0.0012)\end{array}$ & $\begin{array}{c}0.0062^{* * *} \\
(0.0011)\end{array}$ & $\begin{array}{c}0.0056 * * * \\
(0.0014)\end{array}$ & $\begin{array}{c}0.0056 * * * \\
(0.0016)\end{array}$ & $\begin{array}{l}-0.0009 \\
(0.0007)\end{array}$ & $\begin{array}{l}-0.0008 \\
(0.0007)\end{array}$ \\
\hline Inflation & $\begin{array}{l}-0.0012 \\
(0.0009)\end{array}$ & $\begin{array}{l}-0.0011 \\
(0.0008)\end{array}$ & $\begin{array}{l}-0.0011 \\
(0.0009)\end{array}$ & $\begin{array}{l}-0.0014 \\
(0.0009)\end{array}$ & $\begin{array}{l}-0.0085 \\
(0.0079)\end{array}$ & $\begin{array}{c}0.0095 \\
(0.0087)\end{array}$ & $\begin{array}{l}-0.0010 \\
(0.0009)\end{array}$ & $\begin{array}{l}-0.0006 \\
(0.0008)\end{array}$ & $\begin{array}{l}-0.0011 \\
(0.0009)\end{array}$ & $\begin{array}{l}-0.0010 \\
(0.0008)\end{array}$ & $\begin{array}{l}-0.0025 \\
(0.0071)\end{array}$ & $\begin{array}{c}0.0034 \\
(0.0062)\end{array}$ & $\begin{array}{l}-0.0002 \\
(0.0003)\end{array}$ & $\begin{array}{l}-0.0003 \\
(0.0003)\end{array}$ & $\begin{array}{l}-0.0001 \\
(0.0004)\end{array}$ & $\begin{array}{l}-0.0003 \\
(0.0004)\end{array}$ & $\begin{array}{l}-0.0035 \\
0.0037)\end{array}$ & $\begin{array}{c}0.0068 \\
(0.0089)\end{array}$ \\
\hline \multirow[t]{2}{*}{ Remittance Inflows } & -0.0002 & 0.0003 & -0.0047 & 0.0096 & -0.0695 & $-0.1091 * * *$ & -0.0017 & -0.0006 & 0.0036 & 0.0035 & $-0.1106^{* * *}$ & $\begin{array}{l}-0.11322^{* * *} \\
-\end{array}$ & -0.0026 & -0.0009 & -0.0064 & 0.0064 & $-0.0704^{* * *}$ & $-0.0699 * * *$ \\
\hline & $(0.0023)$ & $(0.0010)$ & $(0.0064)$ & $(0.0072)$ & $(0.0549)$ & $(0.0380)$ & $(0.0031)$ & $(0.0013)$ & $(0.0077)$ & $(0.0052)$ & $(0.0302)$ & $(0.0288)$ & $(0.0020)$ & $(0.0010)$ & $(0.0039)$ & $(0.0078)$ & $(0.0265)$ & $(0.0201)$ \\
\hline Banking Crisis Dummy & $\begin{array}{c}-0.1180^{* * * *} \\
(0.0277)\end{array}$ & $\begin{array}{c}-0.1046 * * * \\
(0.0248)\end{array}$ & $\begin{array}{c}-0.0904^{* * *} \\
(0.0327)\end{array}$ & $\begin{array}{c}-0.0893^{* * * *} \\
(0.0291)\end{array}$ & $\begin{array}{l}-0.0389 \\
(0.0303)\end{array}$ & $\begin{array}{l}-0.0206 \\
(0.0133)\end{array}$ & $\begin{array}{c}-0.1131 * * * \\
(0.0249)\end{array}$ & $\begin{array}{c}-0.1084^{* * *} \\
(0.0238)\end{array}$ & \begin{tabular}{|c|}
$-0.0977 * * *$ \\
$(0.0249)$
\end{tabular} & $\begin{array}{c}-0.1007 * * * \\
(0.0231)\end{array}$ & $\begin{array}{c}0.0115 \\
(0.0141)\end{array}$ & $\begin{array}{l}-0.0013 \\
(0.0088)\end{array}$ & $\begin{array}{c}-0.0562^{* * * *} \\
(0.0126)\end{array}$ & $\begin{array}{c}-0.0607 * * * \\
(0.0121)\end{array}$ & $\begin{array}{c}-0.0481^{* *} \\
(0.0184)\end{array}$ & $\begin{array}{c}-0.0446 * * * \\
(0.0163)\end{array}$ & $\begin{array}{l}-0.0085 \\
(0.0135)\end{array}$ & $\begin{array}{l}-0.0027 \\
(0.0070)\end{array}$ \\
\hline \multicolumn{19}{|l|}{ Openness variables } \\
\hline \multirow[t]{2}{*}{ Financial Openness } & -0.0106 & -0.0057 & -0.0316 & $-0.0208^{*}$ & 0.0011 & 0.0012 & -0.0055 & -0.0007 & 0.0004 & -0.0029 & 0.0030 & $0.0023^{* * *}$ & 0.0009 & -0.0001 & -0.0086 & -0.0030 & 0.0005 & $0.0010^{*}$ \\
\hline & $(0.0076)$ & $(0.0042)$ & $(0.0286)$ & $(0.0111)$ & $(0.0027)$ & $(0.0010)$ & $(0.0072)$ & $(0.0041)$ & $(0.0139)$ & $(0.0100)$ & $(0.0018)$ & $(0.0009)$ & $(0.0051)$ & $(0.0034)$ & $(0.0139)$ & $(0.0065)$ & $(0.0011)$ & $(0.0006)$ \\
\hline \multirow[t]{2}{*}{ Trade Openness } & 0.0004 & 0.0003 & $0.0036^{*}$ & 0.0006 & -0.0029 & 0.0045 & 0.0012 & 0.0003 & $0.0043^{*}$ & $0.0022^{* *}$ & -0.0015 & -0.0017 & $0.0006^{* *}$ & $0.0004^{* *}$ & $0.0035 * * *$ & 0.0007 & $-0.0070^{* *}$ & 0.0013 \\
\hline & $(0.0005)$ & $(0.0003)$ & $(0.0020)$ & $(0.0008)$ & $(0.0058)$ & $(0.0036)$ & $(0.0009)$ & $(0.0003)$ & $(0.0022)$ & $(0.0010)$ & $(0.0041)$ & $(0.0025)$ & $(0.0003)$ & $(0.0002)$ & $(0.0010)$ & $(0.0005)$ & $(0.0031)$ & $(0.0021)$ \\
\hline $\begin{array}{l}\text { Institutional variables } \\
\text { Polity Score }\end{array}$ & 0.0001 & 0.0006 & -0.0019 & 0.0008 & $0.0152^{* * *}$ & $0.0113^{* * *}$ & -0.0001 & 0.0010 & -0.0010 & -0.0002 & $0.0041^{* *}$ & 0.0014 & -0.0011 & & -0.0040 & 0.0010 & & \\
\hline & $(0.0016)$ & $(0.0010)$ & $(0.0052)$ & $(0.0027)$ & $(0.0036)$ & $(0.0042)$ & $(0.0022)$ & $(0.0010)$ & $(0.0044)$ & $(0.0029)$ & $(0.0017)$ & $(0.0016)$ & $(0.0013)$ & $(0.0007)$ & $(0.0026)$ & $(0.0024)$ & $(0.0017)$ & $(0.0013)$ \\
\hline Composite Risk Rating & $0.0022^{*}$ & 0.0009 & $0.0096^{* * *}$ & $0.0068^{*}$ & $-0.1235^{* * *}$ & $-0.1383^{* * *}$ & 0.0008 & -0.0002 & 0.0016 & 0.0010 & $-0.1261^{* * *}$ & $-0.1474^{* * *}$ & $0.0018^{* *}$ & 0.0004 & $0.0026^{*}$ & 0.0014 & $-0.1119 * * *$ & $-0.1261 * * *$ \\
\hline & $(0.0012)$ & $(0.0010)$ & $(0.0030)$ & $(0.0036)$ & $(0.0403)$ & $(0.0389)$ & $(0.0013)$ & $(0.0007)$ & $(0.0016)$ & $(0.0014)$ & $(0.0398)$ & $(0.0392)$ & $(0.0007)$ & $(0.0005)$ & $(0.0014)$ & $(0.0011)$ & $(0.0316)$ & $(0.0339)$ \\
\hline Constant & & -0.0496 & & $-0.3847^{* *}$ & & $-0.6389 * * *$ & & -0.0069 & & -0.1395 & & -0.1524 & & 0.0064 & & -0.0728 & & $-0.1463^{*}$ \\
\hline & & $(0.0623)$ & & $(0.1849)$ & & $(0.2225)$ & & $(0.0532)$ & & $(0.0967)$ & & $(0.0958)$ & & $(0.0334)$ & & $(0.0673)$ & & $(0.0817)$ \\
\hline Observations & 1,537 & 1,614 & 1,537 & 1,614 & 1,534 & 1,611 & 1,754 & 1,866 & 1,754 & 1,866 & 1,855 & 1,967 & 2,122 & 2,236 & 2,122 & 2,236 & 2,116 & 2,230 \\
\hline Time Dummies & YES & YES & YES & YES & YES & YES & YES & YES & YES & YES & YES & YES & YES & YES & YES & YES & YES & YES \\
\hline Number of countries & 77 & 77 & 77 & 77 & 76 & 77 & 112 & 112 & 112 & 112 & 112 & 112 & 113 & 114 & 113 & 114 & 112 & 114 \\
\hline Number of instruments & 66 & 69 & 64 & 75 & 64 & 75 & 56 & 59 & 95 & 106 & 96 & 107 & 66 & 69 & 100 & 111 & 100 & 111 \\
\hline Hansen Test & 0.0646 & 0.0479 & 0.319 & 0.181 & 0.148 & 0.103 & 0.294 & 0.301 & 0.282 & 0.236 & 0.281 & 0.222 & 0.181 & 0.164 & 0.454 & 0.126 & 0.390 & 0.173 \\
\hline $\operatorname{AR}(1)$ & $2.12 \mathrm{e}-05$ & $6.80 \mathrm{e}-06$ & $1.15 \mathrm{e}-05$ & $3.82 \mathrm{e}-06$ & $4.60 \mathrm{e}-08$ & $1.26 \mathrm{e}-08$ & 0.000130 & $1.04 \mathrm{e}-05$ & $5.51 \mathrm{e}-05$ & $9.93 \mathrm{e}-06$ & $8.98 \mathrm{e}-08$ & $1.96 \mathrm{e}-08$ & $1.78 \mathrm{e}-09$ & $1.35 \mathrm{e}-10$ & $6.47 \mathrm{e}-10$ & $6.41 \mathrm{e}-11$ & 0 & 0 \\
\hline $\operatorname{AR}(2)$ & 0.771 & 0.838 & 0.611 & 0.787 & 0.343 & 0.540 & 0.131 & 0.177 & $\begin{array}{c}0.129 \\
\end{array}$ & 0.193 & 0.214 & 0.580 & 0.484 & 0.512 & 0.481 & $\begin{array}{c}0.577 \\
\end{array}$ & 0.973 & 0.745 \\
\hline
\end{tabular}


Table 3a. Summary Statistics and Correlations: Banking Sector Efficiency (gap analysis), Global Sample, Annual Data (1,176 observations, 103 countries)

\begin{tabular}{|c|c|c|c|c|c|c|c|c|c|c|c|c|c|c|c|c|}
\hline \multicolumn{3}{|l|}{ Variable } & Abbreviation & & \multicolumn{2}{|l|}{ Source } & Unit of meas & urement & & & Mean & $\begin{array}{r}\text { Overall } \\
\text { Standard } \\
\text { Deviation }\end{array}$ & $\begin{array}{l}\text { Between } \\
\text { Standard } \\
\text { Deviation }\end{array}$ & $\begin{array}{r}\text { Within } \\
\text { Standard } \\
\text { Deviation }\end{array}$ & Maximum & Minimum \\
\hline \multicolumn{3}{|c|}{ Efficiency Gap (Net Int Margin) } & \multicolumn{2}{|l|}{ NIM_gap } & \multicolumn{2}{|l|}{ FinStats } & \multicolumn{4}{|c|}{ relative deviation from benchmark } & -0.13 & 0.75 & 0.47 & 0.58 & 1.00 & -16.87 \\
\hline \multirow{2}{*}{\multicolumn{3}{|c|}{$\begin{array}{l}\text { Growth Rate } \\
\text { Inflation }\end{array}$}} & \multirow{2}{*}{\multicolumn{2}{|c|}{$\begin{array}{l}\text { Growth } \\
\text { Inf }\end{array}$}} & \multicolumn{2}{|l|}{ WDI } & \multicolumn{4}{|c|}{$\%$ change in real GDP } & 2.77 & 4.01 & 1.92 & 3.52 & 30.34 & -16.59 \\
\hline & & & & & \multirow{2}{*}{\multicolumn{2}{|c|}{$\begin{array}{l}\text { WEO } \\
\text { GFDD }\end{array}$}} & \multicolumn{4}{|c|}{ \% change in CPI } & 6.58 & 9.73 & 6.56 & 7.45 & 168.60 & -8.24 \\
\hline \multicolumn{3}{|c|}{ Remittance Inflows } & \multicolumn{2}{|l|}{ Rem } & & & $\%$ of GDP & & & & 3.17 & 5.09 & 4.85 & 1.64 & 34.50 & 0.00 \\
\hline \multirow{2}{*}{\multicolumn{3}{|c|}{$\begin{array}{l}\text { Banking Crisis } \\
\text { Financial Openness }\end{array}$}} & \multicolumn{2}{|l|}{ Crisis } & \multicolumn{2}{|c|}{ GFDD } & \multicolumn{4}{|c|}{ Dummy variable } & 0.10 & 0.31 & 0.13 & 0.28 & 1 & 0 \\
\hline & & & \multirow{2}{*}{\multicolumn{2}{|c|}{$\begin{array}{l}\text { FO } \\
\text { TO }\end{array}$}} & \multicolumn{2}{|c|}{ Chinn \& Ito (2006) } & Chinn - Ito Ir & & & & 0.69 & 1.58 & 1.52 & 0.52 & 2.44 & -1.86 \\
\hline \multicolumn{3}{|c|}{ Trade Openness } & & & WEO & & $\%$ of GDP & & & & 43.76 & 24.30 & 22.65 & 9.61 & 274.39 & 1.94 \\
\hline Polity Scor & & & Pol & & Polity IV Proj & & Polity Index, & -10 to 10 & & & 5.73 & 5.33 & 5.57 & 1.48 & 10 & -10 \\
\hline Composite & isk Rating & & Risk & & ICRG & & Risk Score, 0 & to 100 & & & 70.75 & 9.10 & 8.63 & 3.35 & 92.38 & 32.80 \\
\hline Lerner Ind & of Banking S & ector & Lerner & & GFDD & & Lerner Index & & & & 0.24 & 0.14 & 0.10 & 0.10 & 0.82 & -1.61 \\
\hline Correlation & matrix & & & & & & & & & & & & & & & \\
\hline & NIM_gap & Growth & $\operatorname{lnf}$ & Rem & Crisis & $\mathrm{FO}$ & TO & Pol & Risk & Lerner & & & & & & \\
\hline $\begin{array}{l}\text { NIM_gap } \\
\end{array}$ & 1.0000 & & & & & & & & & & & & & & & \\
\hline Growth & 0.0318 & 1.0000 & & & & & & & & & & & & & & \\
\hline $\operatorname{lnf}$ & -0.2321 & 0.0111 & 1.0000 & & & & & & & & & & & & & \\
\hline Rem & 0.0722 & 0.0467 & 0.0426 & 1.0000 & & & & & & & & & & & & \\
\hline Crisis & 0.0510 & -0.2484 & 0.0450 & -0.1068 & 1.0000 & & & & & & & & & & & \\
\hline FO & -0.0178 & -0.0864 & -0.2746 & -0.0784 & 0.1074 & 1.0000 & & & & & & & & & & \\
\hline TO & 0.1354 & 0.1071 & -0.0130 & 0.4832 & 0.0305 & 0.1116 & 1.0000 & & & & & & & & & \\
\hline Pol & -0.0961 & -0.0930 & -0.1295 & -0.1430 & 0.1444 & 0.4439 & 0.0395 & 1.0000 & & & & & & & & \\
\hline Risk & 0.0691 & 0.0665 & -0.3874 & -0.3350 & 0.0611 & 0.5627 & -0.0093 & 0.3529 & 1.0000 & & & & & & & \\
\hline Lerner & -0.0239 & 0.1558 & -0.0236 & 0.0321 & -0.1605 & -0.1351 & 0.0694 & -0.2605 & -0.0823 & 1.0000 & & & & & & \\
\hline
\end{tabular}


Table 3b. Determinants of Banking Sector Efficiency (gap analysis)

\begin{tabular}{|c|c|c|c|c|c|c|c|c|}
\hline \multirow[b]{2}{*}{ Variables } & \multirow[b]{2}{*}{ OLS } & \multirow[b]{2}{*}{$\mathrm{FE}$} & \multicolumn{2}{|c|}{ Exogenous } & \multicolumn{2}{|c|}{ Predetermined } & \multicolumn{2}{|c|}{ Endogenous } \\
\hline & & & D GMM & S GMM & D GMM & S GMM & D GMM & S GMM \\
\hline \multicolumn{9}{|l|}{ Lags } \\
\hline Efficiency Gap (t - 1) & $\begin{array}{c}0.4018^{* * * *} \\
(0.0264)\end{array}$ & $\begin{array}{c}0.0987^{* * *} \\
(0.0305)\end{array}$ & $\begin{array}{c}0.2023 * * \\
(0.0874)\end{array}$ & $\begin{array}{c}0.1581^{* * * *} \\
(0.0542)\end{array}$ & $\begin{array}{c}0.2009 * * \\
(0.0941)\end{array}$ & $\begin{array}{c}0.1905^{* * *} \\
(0.0720)\end{array}$ & $\begin{array}{c}0.1871 * * * \\
(0.0690)\end{array}$ & $\begin{array}{c}0.1818^{* * *} \\
(0.0559)\end{array}$ \\
\hline \multicolumn{9}{|l|}{ Policy variables } \\
\hline \multicolumn{9}{|l|}{ Macroeconomic variables } \\
\hline Growth & $\begin{array}{c}0.0037 \\
(0.0054)\end{array}$ & $\begin{array}{c}0.0090 \\
(0.0061)\end{array}$ & $\begin{array}{c}0.0067 \\
(0.0041)\end{array}$ & $\begin{array}{c}0.0041 \\
(0.0047)\end{array}$ & $\begin{array}{c}0.0147^{* * *} \\
(0.0055)\end{array}$ & $\begin{array}{l}0.0093^{*} \\
(0.0054)\end{array}$ & $\begin{array}{c}0.0116 \\
(0.0107)\end{array}$ & $\begin{array}{c}0.0197 \\
(0.0200)\end{array}$ \\
\hline Inflation & $\begin{array}{c}-0.0127 * * * \\
(0.0024)\end{array}$ & $\begin{array}{c}-0.0067^{* *} \\
(0.0028)\end{array}$ & $\begin{array}{c}-0.0065 * * * \\
(0.0016)\end{array}$ & $\begin{array}{c}-0.0129 * * * \\
(0.0027)\end{array}$ & $\begin{array}{c}-0.0040^{* *} \\
(0.0018)\end{array}$ & $\begin{array}{c}-0.0065^{* * *} \\
(0.0020)\end{array}$ & $\begin{array}{c}-0.0085^{*} \\
(0.0048)\end{array}$ & $\begin{array}{l}-0.0055 \\
(0.0037)\end{array}$ \\
\hline Remittance Inflows & $\begin{array}{c}0.0008 \\
(0.0046)\end{array}$ & $\begin{array}{c}0.0102 \\
(0.0117)\end{array}$ & $\begin{array}{c}0.0031 \\
(0.0079)\end{array}$ & $\begin{array}{c}0.0022 \\
(0.0056)\end{array}$ & $\begin{array}{c}0.0263 \\
(0.0219)\end{array}$ & $\begin{array}{c}0.0097 \\
(0.0130)\end{array}$ & $\begin{array}{l}0.0479 * \\
(0.0264)\end{array}$ & $\begin{array}{c}0.0101 \\
(0.0154)\end{array}$ \\
\hline Banking Crisis Dummy & $\begin{array}{c}0.1006 \\
(0.0696)\end{array}$ & $\begin{array}{c}0.0255 \\
(0.0750)\end{array}$ & $\begin{array}{c}0.0187 \\
(0.0524)\end{array}$ & $\begin{array}{l}0.0938^{*} \\
(0.0518)\end{array}$ & $\begin{array}{c}0.2231^{* *} \\
(0.1059)\end{array}$ & $\begin{array}{c}0.1823^{* *} \\
(0.0847)\end{array}$ & $\begin{array}{c}0.0970 \\
(0.1549)\end{array}$ & $\begin{array}{c}0.2987 * * \\
(0.1236)\end{array}$ \\
\hline \multicolumn{9}{|l|}{ Openness variables } \\
\hline Financial Openness & $\begin{array}{c}-0.0236 \\
(0.0157)\end{array}$ & $\begin{array}{c}-0.0804^{* *} \\
(0.0385)\end{array}$ & $\begin{array}{l}-0.0558 \\
(0.0463)\end{array}$ & $\begin{array}{c}-0.0310 \\
(0.0214)\end{array}$ & $\begin{array}{c}0.1056 \\
(0.1006)\end{array}$ & $\begin{array}{c}-0.0469 \\
(0.0464)\end{array}$ & $\begin{array}{c}-0.0753 \\
(0.1378)\end{array}$ & $\begin{array}{c}-0.1147^{* *} \\
(0.0544)\end{array}$ \\
\hline Trade Openness & $\begin{array}{c}0.0028^{* * *} \\
(0.0009)\end{array}$ & $\begin{array}{l}0.0034^{*} \\
(0.0021)\end{array}$ & $\begin{array}{c}0.0031 * * * \\
(0.0009)\end{array}$ & $\begin{array}{c}0.0039 * * * \\
(0.0015)\end{array}$ & $\begin{array}{c}0.0028 \\
(0.0041)\end{array}$ & $\begin{array}{c}0.0010 \\
(0.0014)\end{array}$ & $\begin{array}{c}0.0040 \\
(0.0035)\end{array}$ & $\begin{array}{c}0.0019 \\
(0.0019)\end{array}$ \\
\hline \multicolumn{9}{|l|}{ Institutional variables } \\
\hline Polity Score & $\begin{array}{c}-0.0122 * * * \\
(0.0042)\end{array}$ & $\begin{array}{l}-0.0104 \\
(0.0135)\end{array}$ & $\begin{array}{c}0.0029 \\
(0.0082)\end{array}$ & $\begin{array}{c}-0.0132 * * * \\
(0.0049)\end{array}$ & $\begin{array}{c}0.0222 \\
(0.0222)\end{array}$ & $\begin{array}{c}0.0201 \\
(0.0199)\end{array}$ & $\begin{array}{c}0.0080 \\
(0.0251)\end{array}$ & $\begin{array}{c}0.0134 \\
(0.0163)\end{array}$ \\
\hline Composite Risk Rating & $\begin{array}{c}0.0028 \\
(0.0029)\end{array}$ & $\begin{array}{l}-0.0086 \\
(0.0065)\end{array}$ & $\begin{array}{c}-0.0100 * * \\
(0.0047)\end{array}$ & $\begin{array}{c}0.0040 \\
(0.0036)\end{array}$ & $\begin{array}{c}0.0003 \\
(0.0091)\end{array}$ & $\begin{array}{c}0.0086 \\
(0.0078)\end{array}$ & $\begin{array}{c}0.0030 \\
(0.0123)\end{array}$ & $\begin{array}{c}0.0238^{* * *} \\
(0.0085)\end{array}$ \\
\hline \multicolumn{9}{|l|}{ Market power } \\
\hline Lerner Index & $\begin{array}{c}-0.2638^{*} \\
(0.1490)\end{array}$ & $\begin{array}{c}-0.4853^{* * *} \\
(0.1880)\end{array}$ & $\begin{array}{c}-0.2759 \\
(0.1815)\end{array}$ & $\begin{array}{c}-0.2552^{*} \\
(0.1419)\end{array}$ & $\begin{array}{l}-0.2326 \\
(0.2153)\end{array}$ & $\begin{array}{l}-0.1145 \\
(0.2038)\end{array}$ & $\begin{array}{c}0.0756 \\
(0.3606)\end{array}$ & $\begin{array}{c}-0.0838 \\
(0.3758)\end{array}$ \\
\hline Constant & $\begin{array}{l}-0.1797 \\
(0.2221) \\
\end{array}$ & $\begin{array}{c}0.5503 \\
(0.4679) \\
\end{array}$ & & $\begin{array}{c}-0.4318 \\
(0.2716) \\
\end{array}$ & & $\begin{array}{c}-0.8736 \\
(0.6050) \\
\end{array}$ & & $\begin{array}{c}-1.9343^{* * *} \\
(0.6403) \\
\end{array}$ \\
\hline Observations & 1,176 & 1,176 & 1,134 & 1,237 & 1,134 & 1,237 & 1,073 & 1,176 \\
\hline R-squared & 0.2653 & 0.0526 & & & & & & \\
\hline Time Dummies & YES & YES & YES & YES & YES & YES & YES & YES \\
\hline Number of countries & & 103 & 102 & 103 & 102 & 103 & 102 & 103 \\
\hline Number of instruments & & & 35 & 37 & 83 & 94 & 92 & 103 \\
\hline Hansen Test & & & 0.0810 & 0.121 & 0.635 & 0.269 & 0.552 & 0.501 \\
\hline $\operatorname{AR}(1)$ & & & 0.137 & 0.158 & 0.138 & 0.141 & 0.169 & 0.166 \\
\hline$A R(2)$ & & & 0.826 & 0.410 & 0.891 & 0.707 & 0.589 & 0.486 \\
\hline
\end{tabular}

Standard errors in parentheses

*** $p<0.01, * * p<0.05, * p<0.1$ 
Table 3c. Robustness Checks: Determinants of Banking Sector Efficiency (gap analysis)

\begin{tabular}{|c|c|c|c|c|c|c|c|c|c|c|c|c|c|c|c|c|c|c|}
\hline \multirow[b]{3}{*}{ Variables } & \multicolumn{6}{|c|}{ Developing Countries } & \multicolumn{6}{|c|}{ Pre-GFC (upto 2007) } & \multicolumn{6}{|c|}{ Trimmed Sample } \\
\hline & \multicolumn{2}{|c|}{$\begin{array}{l}\text { Exogenous } \\
\end{array}$} & \multicolumn{2}{|c|}{ Predetermined } & \multicolumn{2}{|c|}{ Endogenous } & \multicolumn{2}{|c|}{$\begin{array}{l}\text { Exogenous } \\
\end{array}$} & \multicolumn{2}{|c|}{ Predetermined } & \multicolumn{2}{|c|}{ Endogenous } & \multicolumn{2}{|c|}{ Exogenous } & \multicolumn{2}{|c|}{ Predetermined } & \multicolumn{2}{|c|}{ Endogenous } \\
\hline & D GMM & S GMM & DGMM & SGMM & DGMM & SGMM & D GMM & SGMM & DGMM & SGMM & D GMM & S GMM & DGMM & SGMM & D GMM & SGMM & DGMM & S GMM \\
\hline $\begin{array}{l}\text { Lags } \\
\quad \text { Efficiency Gap ( } \mathrm{t} \text { - 1) }\end{array}$ & $\begin{array}{c}0.3763 * * * \\
(0.1321)\end{array}$ & $\begin{array}{l}0.3854^{* *} \\
(0.1737)\end{array}$ & $\begin{array}{l}0.3349^{*} \\
(0.1690)\end{array}$ & $\begin{array}{c}0.4306^{* * *} \\
(0.1497)\end{array}$ & $\begin{array}{l}0.3137^{* *} \\
(0.1489)\end{array}$ & $\begin{array}{c}0.4127 * * * \\
(0.1187)\end{array}$ & $\begin{array}{c}0.6031^{* * *} \\
(0.1981)\end{array}$ & $\begin{array}{c}0.1241^{* * *} \\
(0.0228)\end{array}$ & \begin{tabular}{|c|}
$0.5046 * * *$ \\
$(0.1477)$
\end{tabular} & $\begin{array}{c}0.1867 * * \\
(0.0262)\end{array}$ & $\begin{array}{c}0.4423^{* * *} \\
(0.1310)\end{array}$ & $\begin{array}{c}0.1861^{* * *} \\
(0.0324)\end{array}$ & $\begin{array}{c}0.3477^{* * *} \\
(0.0553)\end{array}$ & $\begin{array}{c}0.3249 * * * \\
(0.0462)\end{array}$ & $\begin{array}{c}0.3562^{* * *} \\
(0.0608)\end{array}$ & $\begin{array}{c}0.4820^{* * *} \\
(0.0502)\end{array}$ & $\begin{array}{c}0.3306^{* * *} \\
(0.0543)\end{array}$ & $\begin{array}{c}0.4752^{* * *} \\
(0.0484)\end{array}$ \\
\hline $\begin{array}{l}\text { Policy variables } \\
\text { Macroeconomic variables }\end{array}$ & & & & & & & & & & & & & & & & & & \\
\hline Growth & $\begin{array}{c}0.0053 \\
(0.0034)\end{array}$ & $\begin{array}{c}0.0046 \\
(0.0033)\end{array}$ & $\begin{array}{l}0.0095 * * \\
(0.0041)\end{array}$ & $\begin{array}{l}0.0070^{* *} \\
(0.0034)\end{array}$ & $\begin{array}{c}0.0164 \\
(0.0125)\end{array}$ & $\begin{array}{c}0.0252 \\
(0.0186)\end{array}$ & $\begin{array}{c}0.0039 \\
(0.0060)\end{array}$ & $\begin{array}{c}0.0116 \\
(0.0070)\end{array}$ & $\begin{array}{l}0.0153^{* *} \\
(0.0076)\end{array}$ & $\begin{array}{c}0.0169 \\
(0.0104)\end{array}$ & $\begin{array}{c}0.0198 \\
(0.0143)\end{array}$ & $\begin{array}{c}0.0255 \\
(0.0233)\end{array}$ & $\begin{array}{c}0.0018 \\
(0.0028)\end{array}$ & $\begin{array}{l}-0.0001 \\
(0.0028)\end{array}$ & $\begin{array}{c}0.0057 \\
(0.0038)\end{array}$ & $\begin{array}{c}0.0020 \\
(0.0033)\end{array}$ & $\begin{array}{c}0.0020 \\
(0.0060)\end{array}$ & $\begin{array}{l}-0.0092 \\
(0.0066)\end{array}$ \\
\hline Inflation & $\begin{array}{c}-0.0060^{* * *} \\
(0.0019)\end{array}$ & $\begin{array}{c}\left.-0.0108^{* * *}\right) \\
(0.0021)\end{array}$ & $\begin{array}{c}-0.0054^{* * *} \\
(0.0017)\end{array}$ & $\begin{array}{c}-0.0063^{* *} \\
(0.0024)\end{array}$ & $\begin{array}{l}-0.0078 \\
(0.0053)\end{array}$ & $\begin{array}{l}(0.0036) \\
-0.0038 \\
(0.0056)\end{array}$ & $\begin{array}{l}-0.0043^{*} \\
(0.0022)\end{array}$ & $\begin{array}{c}(0.01370) \\
-0.0137^{* * *} \\
(0.0031)\end{array}$ & $\begin{array}{l}(0.00031 \\
-0.0031 \\
(0.0033)\end{array}$ & $\begin{array}{l}-0.0048^{*} \\
(0.0026)\end{array}$ & $\begin{array}{l}(0.0 .0038 \\
-0.0038 \\
(0.0042)\end{array}$ & $\begin{array}{l}-0.0035 \\
-0.0044)\end{array}$ & $\begin{array}{l}-0.0037^{*} \\
(0.0021)\end{array}$ & $\begin{array}{c}(0.0088) \\
-0.008 * * * \\
(0.0030)\end{array}$ & $\begin{array}{l}(0.0038) \\
-0.0002 \\
(0.0026)\end{array}$ & $\begin{array}{l}-0.0023 \\
-0.0025)\end{array}$ & $\begin{array}{l}-0.0074 \\
(0.0051)\end{array}$ & $\begin{array}{c}(.0006) \\
-0.0113^{* *} \\
(0.0043)\end{array}$ \\
\hline Remittance Inflows & $\begin{array}{l}-0.0059 \\
(0.0062)\end{array}$ & $\begin{array}{r}0.0056 \\
(0.0045)\end{array}$ & $\begin{array}{c}0.0367 \\
(0.0365)\end{array}$ & $\begin{array}{c}0.0050 \\
(0.0080)\end{array}$ & $\begin{array}{c}0.0354 \\
(0.0318)\end{array}$ & $\begin{array}{c}0.0087 \\
(0.0135)\end{array}$ & $\begin{array}{l}-0.0027 \\
(0.0068)\end{array}$ & $\begin{array}{c}0.0024 \\
(0.0072)\end{array}$ & $\begin{array}{l}-0.0113 \\
(0.0359)\end{array}$ & $\begin{array}{c}0.0307 \\
(0.0245)\end{array}$ & $\begin{array}{c}0.0014 \\
(0.0320)\end{array}$ & $\begin{array}{c}0.0248 \\
(0.0209)\end{array}$ & $\begin{array}{c}0.0029 \\
(0.0043)\end{array}$ & $\begin{array}{c}0.0008 \\
(0.0040)\end{array}$ & $\begin{array}{c}0.0129 \\
(0.0124)\end{array}$ & $\begin{array}{l}-0.0031 \\
(0.0063)\end{array}$ & $\begin{array}{l}0.0204^{*} \\
(0.0108)\end{array}$ & $\begin{array}{l}-0.0068 \\
(0.0065)\end{array}$ \\
\hline Banking Crisis Dummy & $\begin{array}{c}0.0691 \\
(0.0949)\end{array}$ & $\begin{array}{c}0.1321 \\
(0.0939)\end{array}$ & $\begin{array}{c}0.0513 \\
(0.1630)\end{array}$ & $\begin{array}{l}0.2228^{*} \\
(0.1134)\end{array}$ & $\begin{array}{l}-0.1209 \\
(0.2602)\end{array}$ & $\begin{array}{c}0.2382 \\
(0.1875)\end{array}$ & $\begin{array}{c}0.0223 \\
(0.0891)\end{array}$ & $\begin{array}{c}0.1026 \\
(0.0877)\end{array}$ & $\begin{array}{l}0.1354 \\
(0.1066)\end{array}$ & $\begin{array}{c}0.0109 \\
(0.1240)\end{array}$ & $\begin{array}{c}0.1735 \\
(0.2082)\end{array}$ & $\begin{array}{c}0.2101 \\
(0.1770)\end{array}$ & $\begin{array}{c}0.0308 \\
(0.0337)\end{array}$ & $\begin{array}{l}0.0647^{*} \\
(0.0368)\end{array}$ & $\begin{array}{l}0.1376 \\
(0.0848)\end{array}$ & $\begin{array}{c}0.0661 \\
(0.0434)\end{array}$ & $\begin{array}{l}0.1067 \\
(0.0952)\end{array}$ & $\begin{array}{c}0.0744 \\
(0.0589)\end{array}$ \\
\hline Financial Openness & $\begin{array}{c}-0.0846^{* *} \\
(0.0416)\end{array}$ & $\begin{array}{c}-0.0442^{* * *} \\
(0.0162)\end{array}$ & $\begin{array}{c}0.0229 \\
(0.0913)\end{array}$ & $\begin{array}{l}-0.0425 \\
(0.0544)\end{array}$ & $\begin{array}{l}-0.0982 \\
(0.1115)\end{array}$ & $\begin{array}{l}-0.0856 \\
(0.0527)\end{array}$ & $\begin{array}{l}-0.0416 \\
(0.0413)\end{array}$ & $\begin{array}{l}-0.0293 \\
(0.0328)\end{array}$ & $\begin{array}{c}0.0546 \\
(0.1096)\end{array}$ & $\begin{array}{l}-0.1177^{*} \\
(0.0688)\end{array}$ & $\begin{array}{l}-0.1470^{*} \\
(0.0879)\end{array}$ & $\begin{array}{c}-0.1397^{* *} \\
(0.0688)\end{array}$ & $\begin{array}{l}-0.0164 \\
(0.0207)\end{array}$ & $\begin{array}{l}-0.0140 \\
(0.0129)\end{array}$ & $\begin{array}{c}0.0222 \\
(0.0567)\end{array}$ & $\begin{array}{l}-0.0424^{*} \\
(0.0238)\end{array}$ & $\begin{array}{l}-0.0406 \\
(0.0502)\end{array}$ & $\begin{array}{c}-0.0750^{* * *} \\
(0.0265)\end{array}$ \\
\hline Trade Openness & $0.0025^{*}$ & 0.0009 & 0.0051 & 0.0004 & 0.0052 & 0.0002 & $\begin{array}{l}0.0045 \\
0.004\end{array}$ & $0.0047^{*}$ & 0.0100 & -0.0040 & $0.0228^{* *}$ & -0.0002 & $0.0012^{* *}$ & $0.0015^{*}$ & 0.0033 & $\begin{array}{l}0.0011 \\
0.001\end{array}$ & $\begin{array}{l}0.0017 \\
0.007\end{array}$ & $0.0031^{* * *}$ \\
\hline Institutional variables & $(0.0013)$ & $(0.0010)$ & $(0.0049)$ & $(0.0012)$ & $(0.0048)$ & $(0.0020)$ & $(0.0035)$ & $(0.0025)$ & $(0.0209)$ & $(0.0047)$ & $(0.0106)$ & $(0.0044)$ & $(0.0005)$ & $(0.0008)$ & $(0.0029)$ & $(0.0007)$ & $(0.0023)$ & $(0.0008)$ \\
\hline Polity Score & $\begin{array}{l}-0.0056 \\
(0.0073)\end{array}$ & $\begin{array}{l}-0.0109 * \\
(0.0057)\end{array}$ & $\begin{array}{c}0.0097 \\
(0.0200)\end{array}$ & $\begin{array}{c}0.0039 \\
(0.0177)\end{array}$ & $\begin{array}{l}-0.0065 \\
(0.0231)\end{array}$ & $\begin{array}{l}-0.0019 \\
(0.0152)\end{array}$ & $\begin{array}{c}0.0009 \\
(0.0069)\end{array}$ & $\begin{array}{c}-0.0156 * * * \\
(0.0059)\end{array}$ & $\begin{array}{c}0.0204 \\
(0.0301)\end{array}$ & $\begin{array}{c}0.0210 \\
(0.0215)\end{array}$ & $\begin{array}{l}-0.0288 \\
(0.0372)\end{array}$ & $\begin{array}{c}0.0051 \\
(0.0222)\end{array}$ & $\begin{array}{c}0.0014 \\
(0.0051)\end{array}$ & $\begin{array}{c}-0.0104 * * * \\
(0.0034)\end{array}$ & $\begin{array}{c}0.0123 \\
(0.0145)\end{array}$ & $\begin{array}{l}-0.0018 \\
(0.0094)\end{array}$ & $\begin{array}{l}-0.0068 \\
(0.0166)\end{array}$ & $\begin{array}{l}-0.0054 \\
(0.0100)\end{array}$ \\
\hline Composite Risk Rating & -0.0055 & 0.0018 & -0.0055 & 0.0093 & -0.0011 & 0.0199 & $-0.0101^{* *}$ & 0.0028 & -0.0020 & $0.0341^{* * *}$ & 0.0081 & $0.0459 * * *$ & -0.0042 & $0.0047^{* *}$ & 0.0045 & 0.0061 & 0.0006 & $0.0097^{* *}$ \\
\hline Market power & $(0.0041)$ & $(0.0034)$ & $(0.0098)$ & $(0.0133)$ & $(0.0128)$ & $(0.0123)$ & $(0.0045)$ & $(0.0048)$ & $(0.0145)$ & $(0.0125)$ & $(0.0141)$ & $(0.0137)$ & $(0.0031)$ & $(0.0022)$ & $(0.0066)$ & $(0.0047)$ & $(0.0064)$ & $(0.0048)$ \\
\hline Lerner Index & $\begin{array}{c}-0.6063 * * * \\
(0.1575)\end{array}$ & $\begin{array}{c}-0.2636^{*} \\
(0.1474) \\
-0.1084 \\
(0.2307)\end{array}$ & $\begin{array}{l}-0.5443^{*} \\
(0.2848)\end{array}$ & $\begin{array}{l}-0.3351 \\
(0.2609) \\
-0.7118 \\
(0.9507)\end{array}$ & $\begin{array}{c}-0.7994^{* *} \\
(0.3335)\end{array}$ & $\begin{array}{l}-0.3467 \\
(0.2620) \\
-1.3834 \\
(0.8687)\end{array}$ & $\begin{array}{c}-0.4007 * * \\
(0.1801)\end{array}$ & $\begin{array}{c}-0.3818^{* * *} \\
(0.1384) \\
-0.2342 \\
(0.3311)\end{array}$ & $\begin{array}{l}-0.2277 \\
(0.3064)\end{array}$ & $\begin{array}{c}-0.4199 \\
(0.4452) \\
-2.3645^{* * *} \\
(0.8777)\end{array}$ & $\begin{array}{l}-0.0576 \\
(0.5496)\end{array}$ & $\begin{array}{c}-0.0811 \\
(0.3543) \\
-3.3350^{* * *} \\
(1.0352)\end{array}$ & $\begin{array}{c}-0.2942^{* * *} \\
(0.1053)\end{array}$ & $\begin{array}{c}-0.2082^{* *} \\
(0.0912) \\
-0.2720 \\
(0.1707)\end{array}$ & $\begin{array}{l}-0.0129 \\
(0.1351)\end{array}$ & $\begin{array}{c}0.0115 \\
(0.1309) \\
-0.4489 \\
(0.3367)\end{array}$ & $\begin{array}{l}-0.3134 \\
(0.2367)\end{array}$ & $\begin{array}{c}-0.2752 \\
(0.1859) \\
-0.6030^{*} \\
(0.3259)\end{array}$ \\
\hline Observations & 668 & 733 & 712 & 777 & 670 & 735 & 700 & 800 & 698 & 796 & 707 & 807 & 993 & 1,095 & 1,053 & 1,156 & 999 & 1,102 \\
\hline Time Dummies & YES & YES & YES & YES & YES & YES & YES & YES & YES & YES & YES & YES & YES & YES & YES & YES & YES & YES \\
\hline Number of countries & 65 & 65 & 65 & 65 & 65 & 65 & 98 & 100 & 98 & 98 & 98 & 100 & 102 & 102 & 102 & 103 & 102 & 103 \\
\hline Number of instruments & 33 & 35 & 53 & 64 & 52 & 63 & 25 & 27 & 78 & 89 & 88 & 99 & 33 & 35 & 83 & 94 & 92 & 103 \\
\hline Hansen Test & 0.293 & 0.438 & 0.493 & 0.408 & 0.432 & & 0.341 & 0.18 & 0.680 & 0.248 & 0.328 & 0.178 & 0.386 & 0.546 & 0.842 & 0.457 & 0.700 & 0.404 \\
\hline $\operatorname{AR}(1)$ & 0.00288 & 0.0108 & 0.00490 & 0.00152 & 0.00507 & 0.00244 & 0.288 & 0.232 & 0.272 & 0.224 & 0.271 & 0.215 & $2.27 \mathrm{e}-08$ & $1.95 \mathrm{e}-09$ & $1.27 \mathrm{e}-07$ & $3.77 \mathrm{e}-09$ & $1.65 \mathrm{e}-08$ & $7.44 \mathrm{e}-10$ \\
\hline $\operatorname{AR}(2)$ & 0.481 & 0.471 & 0.464 & 0.491 & 0.634 & 0.730 & 0.236 & 0.144 & 0.230 & 0.191 & 0.237 & 0.213 & 0.834 & 0.884 & 0.963 & 0.529 & 0.958 & 0.704 \\
\hline
\end{tabular}


Table 4a. Summary Statistics and Correlations: Banking Sector Stability (gap analysis), Global Sample, Annual Data (927 observations, 85 countries)

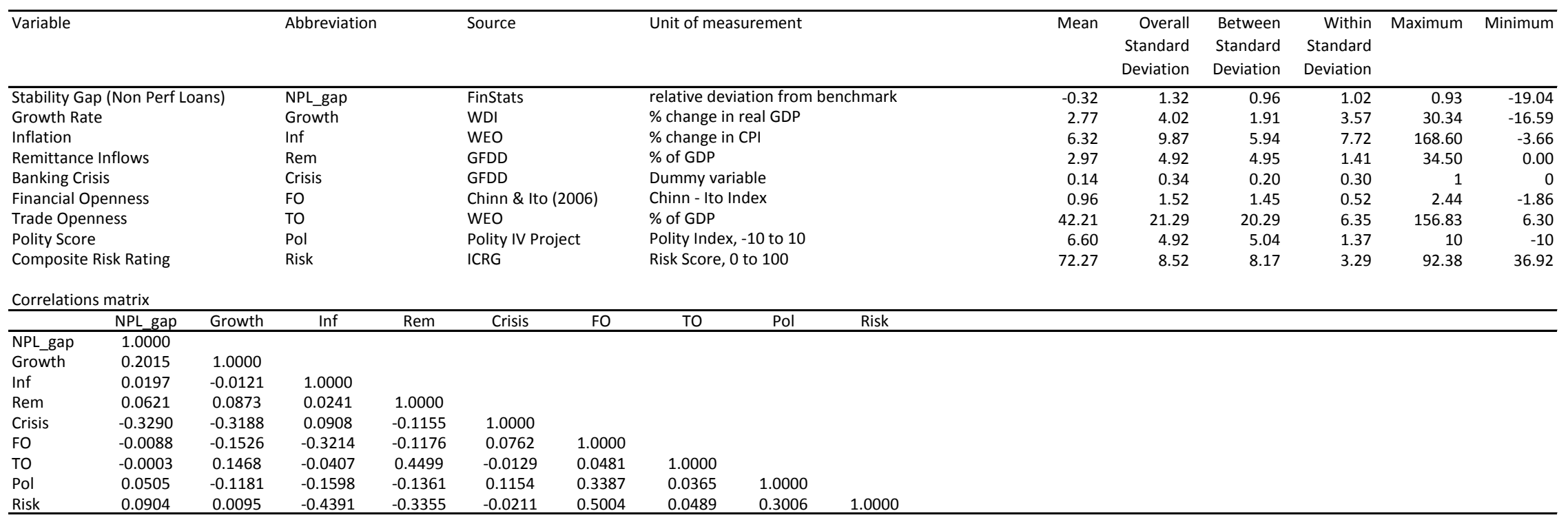


Table 4b. Determinants of Banking Sector Stability (gap analysis)

\begin{tabular}{|c|c|c|c|c|c|c|c|c|}
\hline \multirow[b]{2}{*}{ Variables } & \multirow[b]{2}{*}{ OLS } & \multirow[b]{2}{*}{$\mathrm{FE}$} & \multicolumn{2}{|c|}{ Exogenous } & \multicolumn{2}{|c|}{ Predetermined } & \multicolumn{2}{|c|}{ Endogenous } \\
\hline & & & D GMM & S GMM & D GMM & S GMM & D GMM & SGMM \\
\hline \multicolumn{9}{|l|}{ Lags } \\
\hline Stability Gap (t - 1) & $\begin{array}{c}0.8976 * * * \\
(0.0223)\end{array}$ & $\begin{array}{c}0.7713^{* * *} \\
(0.0300)\end{array}$ & $\begin{array}{c}0.6039 * * * \\
(0.1184)\end{array}$ & $\begin{array}{c}0.9356 * * * \\
(0.1603)\end{array}$ & $\begin{array}{c}0.6224^{* * *} \\
(0.1369)\end{array}$ & $\begin{array}{c}0.9403 * * * \\
(0.1097)\end{array}$ & $\begin{array}{c}0.5247^{* * *} \\
(0.1123)\end{array}$ & $\begin{array}{c}0.7655^{* * *} \\
(0.1938)\end{array}$ \\
\hline \multicolumn{9}{|l|}{ Policy variables } \\
\hline \multicolumn{9}{|l|}{ Macroeconomic variables } \\
\hline Growth & $\begin{array}{c}0.0500^{* * *} \\
(0.0075)\end{array}$ & $\begin{array}{c}0.0447^{* * *} \\
(0.0087)\end{array}$ & $\begin{array}{c}0.0412 * * \\
(0.0159)\end{array}$ & $\begin{array}{c}0.0294 * * \\
(0.0137)\end{array}$ & $\begin{array}{c}0.0483^{* * *} \\
(0.0165)\end{array}$ & $\begin{array}{c}0.0296 * * * \\
(0.0110)\end{array}$ & $\begin{array}{c}0.0111 \\
(0.0420)\end{array}$ & $\begin{array}{c}0.0592 * * * \\
(0.0182)\end{array}$ \\
\hline Inflation & $\begin{array}{c}0.0079 * * \\
(0.0036)\end{array}$ & $\begin{array}{c}0.0091^{* *} \\
(0.0045)\end{array}$ & $\begin{array}{c}0.0099 \\
(0.0077)\end{array}$ & $\begin{array}{c}0.0057 \\
(0.0045)\end{array}$ & $\begin{array}{c}0.0103 \\
(0.0064)\end{array}$ & $\begin{array}{l}0.0066^{*} \\
(0.0036)\end{array}$ & $\begin{array}{c}0.0271 \\
(0.0165)\end{array}$ & $\begin{array}{l}0.0186^{*} \\
(0.0095)\end{array}$ \\
\hline Remittance Inflows & $\begin{array}{c}0.0180^{* * *} \\
(0.0061)\end{array}$ & $\begin{array}{c}0.0144 \\
(0.0197)\end{array}$ & $\begin{array}{c}0.0176 \\
(0.0120)\end{array}$ & $\begin{array}{c}0.0181 * * \\
(0.0079)\end{array}$ & $\begin{array}{l}-0.0542 \\
(0.0665)\end{array}$ & $\begin{array}{c}0.0262 \\
(0.0253)\end{array}$ & $\begin{array}{l}-0.1137 \\
(0.0924)\end{array}$ & $\begin{array}{c}0.0280 \\
(0.0478)\end{array}$ \\
\hline Banking Crisis Dummy & $\begin{array}{c}-0.3968 * * * \\
(0.0832)\end{array}$ & $\begin{array}{c}-0.3840 * * * \\
(0.0945)\end{array}$ & $\begin{array}{c}-0.2975^{*} \\
(0.1757)\end{array}$ & $\begin{array}{l}-0.0540 \\
(0.0973)\end{array}$ & $\begin{array}{c}-0.3641^{*} \\
(0.1906)\end{array}$ & $\begin{array}{c}-0.2674 * \\
(0.1430)\end{array}$ & $\begin{array}{l}-0.1952 \\
(0.3109)\end{array}$ & $\begin{array}{c}-0.5720^{* *} \\
(0.2533)\end{array}$ \\
\hline \multicolumn{9}{|l|}{ Openness variables } \\
\hline Financial Openness & $\begin{array}{c}-0.0039 \\
(0.0195)\end{array}$ & $\begin{array}{l}-0.0729 \\
(0.0505)\end{array}$ & $\begin{array}{l}-0.0453 \\
(0.0328)\end{array}$ & $\begin{array}{c}-0.0091 \\
(0.0163)\end{array}$ & $\begin{array}{l}-0.1658 \\
(0.1847)\end{array}$ & $\begin{array}{c}-0.1401^{* *} \\
(0.0699)\end{array}$ & $\begin{array}{l}-0.1410 \\
(0.2672)\end{array}$ & $\begin{array}{l}-0.0847 \\
(0.0581)\end{array}$ \\
\hline Trade Openness & $\begin{array}{c}-0.0040^{* * * *} \\
(0.0013)\end{array}$ & $\begin{array}{c}0.0042 \\
(0.0048)\end{array}$ & $\begin{array}{l}-0.0017 \\
(0.0042)\end{array}$ & $\begin{array}{l}-0.0043^{*} \\
(0.0024)\end{array}$ & $\begin{array}{c}0.0307 \\
(0.0296)\end{array}$ & $\begin{array}{c}-0.0139 * * \\
(0.0054)\end{array}$ & $\begin{array}{c}0.0280 \\
(0.0232)\end{array}$ & $\begin{array}{l}-0.0054 \\
(0.0078)\end{array}$ \\
\hline \multicolumn{9}{|l|}{ Institutional variables } \\
\hline Polity Score & $\begin{array}{l}0.0096 * \\
(0.0054)\end{array}$ & $\begin{array}{l}-0.0171 \\
(0.0202)\end{array}$ & $\begin{array}{c}-0.0249 \\
(0.0183)\end{array}$ & $\begin{array}{c}0.0045 \\
(0.0060)\end{array}$ & $\begin{array}{c}0.0463 \\
(0.0502)\end{array}$ & $\begin{array}{c}0.0326 \\
(0.0345)\end{array}$ & $\begin{array}{c}0.0756 \\
(0.0731)\end{array}$ & $\begin{array}{c}0.0266 \\
(0.0307)\end{array}$ \\
\hline Composite Risk Rating & $\begin{array}{c}0.0101^{* *} \\
(0.0042)\end{array}$ & $\begin{array}{c}0.0456 * * * \\
(0.0103)\end{array}$ & $\begin{array}{c}0.0452 \\
(0.0306)\end{array}$ & $\begin{array}{c}0.0047 \\
(0.0047)\end{array}$ & $\begin{array}{l}0.0676^{*} \\
(0.0364)\end{array}$ & $\begin{array}{c}0.0286 \\
(0.0182)\end{array}$ & $\begin{array}{c}0.1242 \\
(0.0750)\end{array}$ & $\begin{array}{c}0.0283^{* *} \\
(0.0141)\end{array}$ \\
\hline Constant & $\begin{array}{c}-0.5990^{*} \\
(0.3155) \\
\end{array}$ & $\begin{array}{c}-3.8178^{* * *} \\
(0.7801) \\
\end{array}$ & & $\begin{array}{c}-0.4280 \\
(0.3818) \\
\end{array}$ & & $\begin{array}{r}-1.8935 \\
(1.3511) \\
\end{array}$ & & $\begin{array}{c}-2.0215^{* *} \\
(0.9651) \\
\end{array}$ \\
\hline Observations & 927 & 927 & 904 & 989 & 894 & 979 & 842 & 927 \\
\hline R-squared & 0.7172 & 0.5893 & & & & & & \\
\hline Time Dummies & YES & YES & YES & YES & YES & YES & YES & YES \\
\hline Number of countries & & 85 & 84 & 85 & 84 & 85 & 84 & 85 \\
\hline Number of instruments & & & 34 & 36 & 67 & 77 & 75 & 85 \\
\hline Hansen Test & & & 0.401 & 0.188 & 0.388 & 0.240 & 0.571 & 0.469 \\
\hline$A R(1)$ & & & 0.0405 & 0.104 & 0.118 & 0.135 & 0.00213 & 0.0512 \\
\hline$A R(2)$ & & & 0.818 & 0.714 & 0.508 & 0.549 & 0.542 & 0.356 \\
\hline
\end{tabular}

Standard errors in parentheses

$* * * p<0.01, * * p<0.05, * p<0.1$ 
Table 4c. Robustness Checks: Determinants of Banking Sector Stability (gap analysis)

\begin{tabular}{|c|c|c|c|c|c|c|c|c|c|c|c|c|c|c|c|c|c|c|}
\hline \multirow[b]{3}{*}{ Variables } & \multicolumn{6}{|c|}{ Developing Countries } & \multicolumn{6}{|c|}{ Pre-GFC (upto 2007) } & \multirow{2}{*}{\multicolumn{6}{|c|}{$\begin{array}{l}\text { Trimmed Sample } \\
\end{array}$}} \\
\hline & \multicolumn{2}{|c|}{ Exogenous } & \multicolumn{2}{|c|}{ Predetermined } & \multicolumn{2}{|c|}{ Endogenous } & \multicolumn{2}{|c|}{ Exogenous } & \multicolumn{2}{|c|}{ Predetermined } & \multicolumn{2}{|c|}{ Endogenous } & \multicolumn{2}{|c|}{ Exogenous } & & & \multicolumn{2}{|c|}{ Endogenous } \\
\hline & DGMM & SGMM & D GMM & SGMM & D GMM & SGMM & D GMM & SGMM & DGMM & SGMM & D GMM & SGMM & DGMM & SGMM & D GMM & SGMM & D GMM & SGMM \\
\hline $\begin{array}{l}\text { Lags } \\
\text { Stability Gap (t - 1) }\end{array}$ & $0.9231^{* * *}$ & $\begin{array}{c}1.0271^{* * *} \\
\end{array}$ & $0.9156 * * *$ & $0.9826^{* * *}$ & $0.8771 * * *$ & $0.9306^{* * *}$ & $0.6036 * * *$ & 0.5121 & $0.4972^{* * *}$ & $0.6782^{* * *}$ & $0.5166 * * *$ & $0.5801^{* * *}$ & $0.8038 * * *$ & $0.9364^{* * *}$ & $0.7615^{* * *}$ & $0.8901^{* * *}$ & $0.7769^{* * *}$ & $0.8645 * * *$ \\
\hline $\begin{array}{l}\text { Policy variables } \\
\text { Macroeconomic variables }\end{array}$ & $(0.0978)$ & $(0.0564)$ & $(0.1191)$ & $(0.0707)$ & $(0.0613)$ & $(0.0561)$ & $(0.1015)$ & (0.3326) & $(0.1299)$ & $(0.1670)$ & $(0.0973)$ & $(0.2168)$ & $(0.0663)$ & $(0.0581)$ & $(0.0677)$ & $(0.0559)$ & $(0.0617)$ & $(0.0555)$ \\
\hline Growth & 0.0122 & 0.0062 & 0.0092 & 0.0051 & $0.0745^{* *}$ & $0.0616^{* * *}$ & 0.0349 & 0.0461 & 0.0176 & $0.0286^{*}$ & $0.0509^{* *}$ & 0.0228 & $0.0183^{* *}$ & $0.0140^{*}$ & $0.0232^{* * *}$ & $0.0256^{* * *}$ & $0.0504^{* * *}$ & $0.0606 * * *$ \\
\hline & $(0.0124)$ & $(0.0111)$ & $(0.0157)$ & $(0.0127)$ & $(0.0288)$ & $(0.0214)$ & $(0.0220)$ & $(0.0281)$ & $(0.0163)$ & $(0.0150)$ & $(0.0221)$ & $(0.0213)$ & $(0.0079)$ & (0.0071) & $(0.0085)$ & $(0.0092)$ & $(0.0188)$ & $(0.0183)$ \\
\hline Inflation & $\begin{array}{c}0.0019 \\
(0.0028)\end{array}$ & $\begin{array}{c}0.0021 \\
(0.0023)\end{array}$ & $\begin{array}{c}0.0012 \\
(0.0041)\end{array}$ & $\begin{array}{c}0.0039 \\
(0.0030)\end{array}$ & $\begin{array}{c}0.0099 \\
(0.0065)\end{array}$ & $\begin{array}{c}0.0072 \\
(0.0051)\end{array}$ & $\begin{array}{c}0.0000 \\
(0.0027)\end{array}$ & $\begin{array}{c}0.0051 \\
(0.0033)\end{array}$ & $\begin{array}{l}-0.0025 \\
(0.0030)\end{array}$ & $\begin{array}{l}0.0053^{*} \\
(0.0030)\end{array}$ & $\begin{array}{l}-0.0144 \\
(0.0097)\end{array}$ & $\begin{array}{l}-0.0028 \\
(0.0069)\end{array}$ & $\begin{array}{c}0.0021 \\
(0.0028)\end{array}$ & $\begin{array}{c}0.0027 \\
(0.0024)\end{array}$ & $\begin{array}{l}0.0024 \\
(0.0020)\end{array}$ & $\begin{array}{l}0.0038 \\
(0.0025)\end{array}$ & $\begin{array}{c}0.0052 \\
(0.0044)\end{array}$ & $\begin{array}{c}0.0103^{* *} \\
(0.0048)\end{array}$ \\
\hline Remittance Inflows & 0.0064 & 0.0054 & -0.0082 & -0.0069 & -0.0103 & 0.0079 & 0.0078 & 0.0109 & 0.0417 & 0.0045 & 0.0913 & -0.0131 & $0.0180^{*}$ & $0.0070^{*}$ & 0.0164 & $0.0333^{*}$ & 0.0117 & $0.0309^{*}$ \\
\hline & $(0.0101)$ & $(0.0064)$ & $(0.0512)$ & $(0.0186)$ & $(0.0341)$ & $(0.0281)$ & $(0.0135)$ & $(0.0129)$ & $(0.0405)$ & $(0.0199)$ & $(0.0694)$ & $(0.0251)$ & $(0.0105)$ & $(0.0040)$ & $(0.0335)$ & $(0.0172)$ & $(0.0293)$ & $(0.0173)$ \\
\hline Banking Crisis Dummy & -0.0390 & -0.0403 & -0.3533 & -0.2951 & -0.0536 & $-0.4908^{*}$ & 0.1471 & -0.0232 & -0.3638 & -0.1109 & $-0.7711^{*}$ & -0.5131 & $-0.1429^{*}$ & -0.0619 & -0.2341 & $-0.1422^{*}$ & -0.1910 & $-0.1982^{* *}$ \\
\hline & $(0.1365)$ & $(0.1540)$ & $(0.2991)$ & $(0.2010)$ & $(0.2458)$ & $(0.2887)$ & $(0.2537)$ & $(0.2261)$ & $(0.2273)$ & $(0.2058)$ & $(0.4021)$ & $(0.4015)$ & $(0.0742)$ & $(0.0726)$ & $(0.1469)$ & $(0.0854)$ & $(0.1793)$ & $(0.0875)$ \\
\hline Openness variables & & & & & & & & & & & & & & & & & & \\
\hline Financial Openness & -0.0415 & 0.0010 & -0.0282 & -0.0293 & 0.0796 & -0.0675 & -0.0048 & 0.0292 & -0.1314 & -0.0619 & -0.3292 & -0.0038 & -0.0462 & -0.0117 & -0.1596 & -0.0336 & -0.0672 & -0.0413 \\
\hline & $(0.0393)$ & $(0.0173)$ & $(0.1692)$ & $(0.0527)$ & $(0.1269)$ & $(0.0457)$ & $(0.0443)$ & $(0.0317)$ & $(0.1458)$ & $(0.0667)$ & $(0.2569)$ & $(0.0960)$ & $(0.0302)$ & $(0.0148)$ & (0.1449) & $(0.0366)$ & $(0.1236)$ & $(0.0427)$ \\
\hline Trade Openness & -0.0063 & -0.0015 & 0.0277 & -0.0070 & -0.0014 & -0.0020 & 0.0028 & 0.0004 & 0.0121 & 0.0036 & -0.0021 & 0.0099 & -0.0046 & $-0.0016^{*}$ & -0.0081 & -0.0041 & -0.0085 & -0.0033 \\
\hline Institutional variables & $(0.0042)$ & $(0.0018)$ & $(0.0281)$ & $(0.0046)$ & $(0.0153)$ & $(0.0039)$ & $(0.0054)$ & $(0.0025)$ & $(0.0142)$ & $(0.0058)$ & $(0.0154)$ & $(0.0069)$ & $(0.0032)$ & (0.0009) & $(0.0145)$ & $(0.0042)$ & $(0.0089)$ & $(0.0026)$ \\
\hline Polity Score & -0.0079 & 0.0030 & 0.0640 & 0.0198 & 0.0228 & 0.0274 & -0.0176 & $0.0230^{*}$ & -0.0394 & 0.0436 & -0.0757 & 0.0268 & -0.0106 & 0.0017 & 0.0566 & -0.0149 & 0.0624 & 0.0065 \\
\hline & $\begin{array}{l}(0.0115) \\
-0.0033\end{array}$ & $\begin{array}{l}(0.0057) \\
-0.0047\end{array}$ & $\begin{array}{l}(0.0572) \\
-0.0337\end{array}$ & $\begin{array}{l}(0.0232) \\
-0.0070\end{array}$ & $(0.0360)$ & $(0.0260)$ & $(0.0160)$ & $(0.0125)$ & $(0.0432)$ & $(0.0309)$ & (0.0578) & $(0.0419)$ & $(0.0109)$ & $(0.0033)$ & $(0.0400)$ & $(0.0201)$ & $(0.0476)$ & $(0.0276)$ \\
\hline Composite Risk Rating & -0.0033 & -0.0047 & -0.0337 & -0.0070 & 0.0233 & 0.0014 & -0.0113 & 0.0037 & 0.0032 & 0.0208 & -0.0433 & -0.0034 & 0.0096 & 0.0025 & 0.0203 & 0.0122 & $0.0298^{*}$ & $0.0311^{* *}$ \\
\hline Constant & (0.0109) & $\begin{array}{c}(0.0060) \\
0.1731 \\
(0.3640) \\
\end{array}$ & $(0.0309)$ & $\begin{array}{c}(0.0183) \\
0.7749 \\
(1.3199) \\
\end{array}$ & $(0.0292)$ & $\begin{array}{c}(0.0217) \\
-0.0844 \\
(1.4481) \\
\end{array}$ & $(0.0170)$ & $\begin{array}{c}(0.0070) \\
-0.9675 \\
(0.7833) \\
\end{array}$ & $(0.0131)$ & $\begin{array}{c}(0.0140) \\
-1.8648^{*} \\
(1.0695) \\
\end{array}$ & $(0.0333)$ & $\begin{array}{c}(0.0152) \\
-0.0780 \\
(1.0630) \\
\end{array}$ & $(0.0083)$ & $\begin{array}{c}(0.0032) \\
-0.0526 \\
(0.2411) \\
\end{array}$ & $(0.0138)$ & $\begin{array}{c}(0.0078) \\
-0.5944 \\
(0.6347) \\
\end{array}$ & $(0.0169)$ & $\begin{array}{c}(0.0119) \\
-2.5342^{* * *} \\
(0.8527) \\
\end{array}$ \\
\hline Observations & 506 & 555 & 504 & 553 & 472 & 521 & 528 & 610 & 518 & 600 & 531 & 613 & 845 & 929 & 835 & 919 & 793 & 877 \\
\hline Time Dummies & YES & YES & YES & YES & YES & YES & YES & YES & YES & YES & YES & YES & YES & YES & YES & YES & YES & YES \\
\hline Number of countries & 48 & 49 & 48 & 49 & 48 & 49 & 81 & 82 & 80 & 82 & 81 & 82 & 83 & 84 & 83 & 84 & 83 & 84 \\
\hline Number of instruments & 34 & 36 & 31 & 41 & 39 & 49 & 24 & 26 & 71 & 81 & 71 & 81 & 34 & 36 & 67 & 77 & 66 & 76 \\
\hline Hansen Test & 0.697 & 0.529 & 0.111 & 0.148 & 0.357 & 0.159 & 0.840 & 0.345 & 0.386 & 0.561 & 0.496 & 0.181 & 0.807 & 0.0146 & 0.519 & 0.291 & 0.660 & 0.253 \\
\hline$A R(1)$ & 0.0128 & 0.00860 & 0.00681 & 0.00424 & 0.00300 & 0.00191 & 0.0251 & 0.362 & 0.0173 & 0.0298 & 0.103 & 0.244 & 0.00373 & 0.00223 & 0.00219 & 0.00180 & 0.00102 & 0.000515 \\
\hline $\operatorname{AR}(2)$ & 0.810 & 0.799 & 0.707 & 0.719 & 0.285 & 0.558 & 0.340 & 0.257 & 0.883 & 0.807 & 0.306 & 0.239 & 0.855 & 0.831 & 0.849 & 0.859 & 0.551 & 0.426 \\
\hline
\end{tabular}


Table 5a. Summary Statistics and Correlations: Banking Sector Depth, Global Sample, Annual Data (2,396 observations, 115 countries)

\begin{tabular}{|c|c|c|c|c|c|c|c|c|c|c|c|c|c|c|c|c|}
\hline \multicolumn{3}{|l|}{ Variable } & Abbreviation & & \multicolumn{2}{|l|}{ Source } & \multicolumn{4}{|c|}{ Unit of measurement } & Mean & $\begin{array}{r}\text { Overall } \\
\text { Standard } \\
\text { Deviation }\end{array}$ & $\begin{array}{l}\text { Between } \\
\text { Standard } \\
\text { Deviation }\end{array}$ & $\begin{array}{r}\text { Within } \\
\text { Standard } \\
\text { Deviation }\end{array}$ & Maximum & Minimum \\
\hline \multicolumn{3}{|c|}{ Private Credit } & \multicolumn{2}{|l|}{ PC } & \multicolumn{2}{|l|}{ FinStats } & \multicolumn{4}{|l|}{$\%$ of GDP } & 45.48 & 41.68 & 36.01 & 19.73 & 294.66 & 0.30 \\
\hline \multirow{2}{*}{\multicolumn{3}{|c|}{$\begin{array}{l}\text { Growth Rate } \\
\text { Inflation }\end{array}$}} & \multirow{2}{*}{\multicolumn{2}{|c|}{$\begin{array}{l}\text { Growth } \\
\text { Inf }\end{array}$}} & \multicolumn{2}{|l|}{ WDI } & \multicolumn{4}{|c|}{$\%$ change in real GDP } & 2.27 & 4.08 & 1.95 & 3.65 & 30.34 & -29.67 \\
\hline & & & & & \multirow{2}{*}{\multicolumn{2}{|c|}{$\begin{array}{l}\text { WEO } \\
\text { GFDD }\end{array}$}} & \multicolumn{4}{|c|}{ \% change in CPI } & 9.91 & 15.42 & 8.66 & 12.66 & 178.70 & -8.24 \\
\hline \multicolumn{3}{|c|}{ Remittance Inflows } & \multicolumn{2}{|l|}{ Rem } & & & \multirow{2}{*}{\multicolumn{4}{|c|}{$\%$ of GDP }} & 2.62 & 4.32 & 4.47 & 1.91 & 34.50 & 0.00 \\
\hline \multirow{2}{*}{\multicolumn{3}{|c|}{$\begin{array}{l}\text { Banking Crisis } \\
\text { Financial Openness }\end{array}$}} & \multicolumn{2}{|l|}{ Crisis } & \multicolumn{2}{|c|}{ GFDD } & & & & & 0.11 & 0.31 & 0.11 & 0.30 & 1 & 0 \\
\hline & & & \multicolumn{2}{|l|}{ FO } & \multicolumn{2}{|c|}{ Chinn \& Ito (2006) } & \multicolumn{4}{|c|}{ Chinn - Ito Index } & 0.31 & 1.57 & 1.39 & 0.84 & 2.44 & -1.86 \\
\hline \multicolumn{3}{|c|}{$\begin{array}{l}\text { Financial Openness } \\
\text { Trade Openness }\end{array}$} & \multirow{2}{*}{\multicolumn{2}{|c|}{$\begin{array}{l}\text { TO } \\
\text { Pol }\end{array}$}} & WEO & & $\%$ of GDP & & & & 37.69 & 22.29 & 21.96 & 10.62 & 274.39 & 1.94 \\
\hline \multicolumn{3}{|c|}{ Polity Score } & & & Polity IV Pro & & Polity Index & 10 to 10 & & & 4.48 & 6.15 & 5.85 & 2.81 & 10 & -10 \\
\hline Composit & sk Rating & & Risk & & ICRG & & Risk Score, & o 100 & & & 67.69 & 11.62 & 9.68 & 6.15 & 92.38 & 28.29 \\
\hline Real GDP & capita & & GDPPC & & WDI & & Thousands & (constant & 05) US\$ & & 9.27 & 12.86 & 13.26 & 2.42 & 66.74 & 0.12 \\
\hline Populatio & & & Pop & & WDI & & Tens of mill & & & & 5.39 & 16.10 & 15.21 & 1.71 & 134.41 & 0.07 \\
\hline Populatio & ensity & & Den & & WDI & & People per & $\mathrm{km}$ of lan & area & & 106.22 & 138.78 & 130.16 & 20.24 & 1174.33 & 1.52 \\
\hline Age Depe & ncy Ratio & & Age & & WDI & & $\%$ of workir & age popul & & & 66.30 & 18.95 & 19.15 & 6.24 & 115.94 & 16.83 \\
\hline Correlatio & natrix & & & & & & & & & & & & & & & \\
\hline & $\mathrm{PC}$ & Growth & $\operatorname{lnf}$ & Rem & Crisis & FO & TO & Pol & Risk & GDPPC & Pop & Den & Age & & & \\
\hline PC & 1.0000 & & & & & & & & & & & & & & & \\
\hline Growth & -0.0098 & 1.0000 & & & & & & & & & & & & & & \\
\hline $\operatorname{lnf}$ & -0.28866 & -0.0826 & 1.0000 & & & & & & & & & & & & & \\
\hline Rem & -0.1514 & 0.0598 & -0.0269 & 1.0000 & & & & & & & & & & & & \\
\hline Crisis & 0.1441 & -0.2242 & 0.1177 & -0.0767 & 1.0000 & & & & & & & & & & & \\
\hline FO & 0.4756 & 0.0422 & -0.2938 & 0.0021 & 0.0088 & 1.0000 & & & & & & & & & & \\
\hline TO & 0.1188 & 0.1104 & -0.1615 & 0.4365 & -0.0103 & 0.1326 & 1.0000 & & & & & & & & & \\
\hline Pol & 0.3682 & 0.0710 & -0.1296 & -0.0842 & 0.0073 & 0.4280 & 0.0682 & 1.0000 & & & & & & & & \\
\hline Risk & 0.5961 & 0.2007 & -0.3826 & -0.1843 & -0.0672 & 0.5880 & 0.0668 & 0.4737 & 1.0000 & & & & & & & \\
\hline GDPPC & 0.6806 & -0.0309 & -0.2347 & -0.2832 & 0.0874 & 0.5762 & -0.0841 & 0.4738 & 0.7041 & 1.0000 & & & & & & \\
\hline Pop & 0.0866 & 0.1646 & -0.0255 & -0.0670 & -0.0103 & -0.1219 & -0.1989 & -0.0690 & 0.0219 & -0.0594 & 1.0000 & & & & & \\
\hline Den & 0.2023 & 0.0734 & -0.0992 & 0.1936 & -0.0179 & 0.0560 & 0.0247 & 0.1480 & 0.0620 & 0.1130 & 0.1989 & 1.0000 & & & & \\
\hline Age & -0.5551 & -0.2428 & 0.1667 & 0.1017 & -0.0269 & -0.4403 & -0.1042 & -0.5004 & -0.6644 & -0.5305 & -0.1236 & -0.1960 & 1.0000 & & & \\
\hline
\end{tabular}


Table 5b. Determinants of Banking Sector Depth

\begin{tabular}{|c|c|c|c|c|c|c|c|c|}
\hline \multirow[b]{2}{*}{ Variables } & \multirow[b]{2}{*}{ OLS } & \multirow[b]{2}{*}{$\mathrm{FE}$} & \multicolumn{2}{|c|}{ Exogenous } & \multicolumn{2}{|c|}{ Predetermined } & \multicolumn{2}{|c|}{ Endogenous } \\
\hline & & & D GMM & S GMM & D GMM & S GMM & D GMM & S GMM \\
\hline \multicolumn{9}{|l|}{ Lags } \\
\hline Private Credit ( $\mathrm{t}$ - 1) & $\begin{array}{c}1.2314 * * * \\
(0.0187)\end{array}$ & $\begin{array}{c}1.1240 * * * \\
(0.0195)\end{array}$ & $\begin{array}{c}0.9356^{* * * *} \\
(0.1212)\end{array}$ & $\begin{array}{c}1.2156^{* * *} \\
(0.0444)\end{array}$ & $\begin{array}{c}1.0572^{* * *} \\
(0.0784)\end{array}$ & $\begin{array}{c}1.2095^{* * *} \\
(0.0467)\end{array}$ & $\begin{array}{c}1.0305^{* * *} \\
(0.0619)\end{array}$ & $\begin{array}{c}1.2218^{* * * *} \\
(0.0375)\end{array}$ \\
\hline Private Credit ( $\mathrm{t}-2)$ & $\begin{array}{c}-0.2432^{* * *} \\
(0.0191)\end{array}$ & $\begin{array}{c}-0.1906 * * * \\
(0.0197)\end{array}$ & $\begin{array}{c}-0.1119 * * \\
(0.0563)\end{array}$ & $\begin{array}{c}-0.2036 * * * \\
(0.0496)\end{array}$ & $\begin{array}{c}-0.1509 * * * \\
(0.0507)\end{array}$ & $\begin{array}{c}-0.2070^{* * *} \\
(0.0497)\end{array}$ & $\begin{array}{c}-0.1530^{* * *} \\
(0.0353)\end{array}$ & $\begin{array}{c}-0.2135^{* * *} \\
(0.0400)\end{array}$ \\
\hline \multicolumn{9}{|l|}{ Policy variables } \\
\hline \multicolumn{9}{|l|}{ Macroeconomic variables } \\
\hline Growth & $\begin{array}{l}-0.0092 \\
(0.0318)\end{array}$ & $\begin{array}{c}-0.0630^{*} \\
(0.0332)\end{array}$ & $\begin{array}{c}0.0842 \\
(0.0674)\end{array}$ & $\begin{array}{c}0.2241 * * * \\
(0.0459)\end{array}$ & $\begin{array}{c}0.1676 * * * \\
(0.0439)\end{array}$ & $\begin{array}{c}0.1982^{* * *} \\
(0.0489)\end{array}$ & $\begin{array}{l}-0.1101 \\
(0.1070)\end{array}$ & $\begin{array}{c}0.1023 \\
(0.1243)\end{array}$ \\
\hline Inflation & $\begin{array}{c}-0.0150 * \\
(0.0084)\end{array}$ & $\begin{array}{c}-0.0271^{* * *} \\
(0.0097)\end{array}$ & $\begin{array}{c}-0.0220 \\
(0.0207)\end{array}$ & $\begin{array}{c}-0.0063 \\
(0.0164)\end{array}$ & $\begin{array}{l}-0.0090 \\
(0.0195)\end{array}$ & $\begin{array}{c}-0.0089 \\
(0.0197)\end{array}$ & $\begin{array}{c}0.0056 \\
(0.0233)\end{array}$ & $\begin{array}{c}0.0232 \\
(0.0180)\end{array}$ \\
\hline Remittance Inflows & $\begin{array}{c}-0.0575 * \\
(0.0314)\end{array}$ & $\begin{array}{c}-0.0844 \\
(0.0610)\end{array}$ & $\begin{array}{l}-0.1218 \\
(0.1112)\end{array}$ & $\begin{array}{c}-0.0373 \\
(0.0247)\end{array}$ & $\begin{array}{c}-0.1833 \\
(0.1796)\end{array}$ & $\begin{array}{l}-0.0216 \\
(0.1286)\end{array}$ & $\begin{array}{l}-0.0781 \\
(0.2228)\end{array}$ & $\begin{array}{c}-0.0733 \\
(0.1421)\end{array}$ \\
\hline Banking Crisis Dummy & $\begin{array}{c}-2.5798^{* * *} \\
(0.3854)\end{array}$ & $\begin{array}{c}-1.9609 * * * \\
(0.4131)\end{array}$ & $\begin{array}{l}-1.5833 \\
(1.0301)\end{array}$ & $\begin{array}{c}-3.4523 * * * \\
(0.6433)\end{array}$ & $\begin{array}{l}-1.3365 \\
(0.8701)\end{array}$ & $\begin{array}{c}-2.9428 * * * \\
(0.6328)\end{array}$ & $\begin{array}{l}-1.2213 \\
(1.2510)\end{array}$ & $\begin{array}{c}-3.4225^{* * *} \\
(0.8330)\end{array}$ \\
\hline \multicolumn{9}{|l|}{ Openness variables } \\
\hline Financial Openness & $\begin{array}{c}-0.0109 \\
(0.0973)\end{array}$ & $\begin{array}{c}0.1443 \\
(0.1519)\end{array}$ & $\begin{array}{c}0.4885 \\
(0.4146)\end{array}$ & $\begin{array}{c}0.0424 \\
(0.0962)\end{array}$ & $\begin{array}{c}0.8238 \\
(0.6261)\end{array}$ & $\begin{array}{c}0.2091 \\
(0.2448)\end{array}$ & $\begin{array}{c}1.0033 \\
(0.7021)\end{array}$ & $\begin{array}{c}0.4213 \\
(0.2769)\end{array}$ \\
\hline Trade Openness & $\begin{array}{c}0.0261 * * * \\
(0.0062)\end{array}$ & $\begin{array}{c}0.0426 * * * \\
(0.0119)\end{array}$ & $\begin{array}{c}0.0601^{* *} \\
(0.0250)\end{array}$ & $\begin{array}{c}0.0148^{* *} \\
(0.0062)\end{array}$ & $\begin{array}{l}0.0765^{*} \\
(0.0431)\end{array}$ & $\begin{array}{c}0.0347^{* *} \\
(0.0156)\end{array}$ & $\begin{array}{c}-0.0203 \\
(0.0459)\end{array}$ & $\begin{array}{c}0.0408 * * \\
(0.0201)\end{array}$ \\
\hline \multicolumn{9}{|l|}{ Institutional variables } \\
\hline Polity Score & $\begin{array}{c}0.0049 \\
(0.0224)\end{array}$ & $\begin{array}{c}-0.0473 \\
(0.0453)\end{array}$ & $\begin{array}{l}-0.0606 \\
(0.0537)\end{array}$ & $\begin{array}{c}0.0096 \\
(0.0195)\end{array}$ & $\begin{array}{l}-0.0269 \\
(0.0951)\end{array}$ & $\begin{array}{l}-0.0242 \\
(0.0575)\end{array}$ & $\begin{array}{c}-0.1018 \\
(0.1050)\end{array}$ & $\begin{array}{l}-0.0261 \\
(0.0660)\end{array}$ \\
\hline Composite Risk Rating & $\begin{array}{c}0.0202 \\
(0.0182)\end{array}$ & $\begin{array}{c}0.1345^{* * *} \\
(0.0258)\end{array}$ & $\begin{array}{c}0.1144^{* * *} \\
(0.0337)\end{array}$ & $\begin{array}{c}0.0040 \\
(0.0202)\end{array}$ & $\begin{array}{c}0.1472^{* * *} \\
(0.0544)\end{array}$ & $\begin{array}{c}0.0485 \\
(0.0508)\end{array}$ & $\begin{array}{c}0.2379 * * * \\
(0.0703)\end{array}$ & $\begin{array}{c}0.1067 * * \\
(0.0482)\end{array}$ \\
\hline \multicolumn{9}{|l|}{ Structural variables } \\
\hline Income Level & $\begin{array}{c}0.0542^{* * *} \\
(0.0162)\end{array}$ & $\begin{array}{c}0.5968^{* * *} \\
(0.0685)\end{array}$ & $\begin{array}{c}1.0157^{* * * *} \\
(0.3569)\end{array}$ & $\begin{array}{l}0.0439 * \\
(0.0244)\end{array}$ & $\begin{array}{c}0.6349 * * * \\
(0.2147)\end{array}$ & $\begin{array}{c}0.0422 \\
(0.0473)\end{array}$ & $\begin{array}{c}0.8044^{* * *} \\
(0.2241)\end{array}$ & $\begin{array}{l}-0.0019 \\
(0.0435)\end{array}$ \\
\hline Population & 0.0038 & 0.0091 & -0.0082 & -0.0053 & 0.0178 & 0.0041 & 0.0497 & 0.0055 \\
\hline & $(0.0077)$ & $(0.0703)$ & $(0.0867)$ & $(0.0060)$ & $(0.0482)$ & $(0.0100)$ & $(0.0544)$ & $(0.0128)$ \\
\hline Population Density & $\begin{array}{c}0.0001 \\
(0.0009)\end{array}$ & $\begin{array}{c}0.0076 \\
(0.0067)\end{array}$ & $\begin{array}{c}0.0151 \\
(0.0109)\end{array}$ & $\begin{array}{c}-0.0005 \\
(0.0011)\end{array}$ & $\begin{array}{c}0.0071 \\
(0.0075)\end{array}$ & $\begin{array}{c}-0.0002 \\
(0.0017)\end{array}$ & $\begin{array}{c}0.0043 \\
(0.0089)\end{array}$ & $\begin{array}{c}0.0006 \\
(0.0018)\end{array}$ \\
\hline Age Dependency & $\begin{array}{c}-0.0215^{* *} \\
(0.0092)\end{array}$ & $\begin{array}{c}0.0178 \\
(0.0268)\end{array}$ & $\begin{array}{c}0.0373 \\
(0.0534)\end{array}$ & $\begin{array}{c}0.0093 \\
(0.0088)\end{array}$ & $\begin{array}{c}0.0380 \\
(0.0363)\end{array}$ & $\begin{array}{c}0.0154 \\
(0.0158)\end{array}$ & $\begin{array}{c}0.0641 \\
(0.0446)\end{array}$ & $\begin{array}{c}0.0263 \\
(0.0188)\end{array}$ \\
\hline Constant & $\begin{array}{c}0.2388 \\
(1.7259) \\
\end{array}$ & $\begin{array}{c}-14.6103^{* * *} \\
(2.7693) \\
\end{array}$ & & $\begin{array}{c}-0.5735 \\
(1.6130) \\
\end{array}$ & & $\begin{array}{r}-3.9096 \\
(3.9078) \\
\end{array}$ & & $\begin{array}{c}-9.5314^{* *} \\
(3.8194) \\
\end{array}$ \\
\hline Observations & 2,396 & 2,396 & 2,278 & 2,393 & 2,278 & 2,393 & 2,281 & 2,396 \\
\hline R-squared & 0.9835 & 0.9346 & & & & & & \\
\hline Time Dummies & YES & YES & YES & YES & YES & YES & YES & YES \\
\hline Number of countries & & 115 & 114 & 115 & 114 & 115 & 113 & 115 \\
\hline Number of instruments & & & 70 & 73 & 104 & 115 & 104 & 115 \\
\hline Hansen Test & & & 0.262 & 0.336 & 0.455 & 0.178 & 0.247 & 0.120 \\
\hline$A R(1)$ & & & 0.00189 & $2.90 e-05$ & 0.000205 & $2.79 e-05$ & 0.000140 & $1.12 \mathrm{e}-05$ \\
\hline$A R(2)$ & & & 0.864 & 0.736 & 0.968 & 0.692 & 0.945 & 0.623 \\
\hline
\end{tabular}

Standard errors in parentheses

$* * * p<0.01, * * p<0.05, * p<0.1$ 
Table 5c. Robustness Checks: Determinants of Banking Sector Depth

\begin{tabular}{|c|c|c|c|c|c|c|c|c|c|c|c|c|c|c|c|c|c|c|}
\hline \multirow[b]{3}{*}{ Variables } & \multicolumn{6}{|c|}{ Developing Countries } & \multicolumn{6}{|c|}{ Pre-GFC (upto 2007) } & \multicolumn{6}{|c|}{ Trimmed Sample } \\
\hline & \multicolumn{2}{|c|}{ Exogenous } & \multicolumn{2}{|c|}{$\begin{array}{l}\text { Predetermined } \\
\end{array}$} & \multicolumn{2}{|c|}{ Endogenous } & \multicolumn{2}{|c|}{ Exogenous } & \multicolumn{2}{|c|}{ Predetermined } & \multicolumn{2}{|c|}{ Endogenous } & \multicolumn{2}{|c|}{ Exogenous } & \multicolumn{2}{|c|}{ Predetermined } & \multicolumn{2}{|c|}{ Endogenous } \\
\hline \multirow{2}{*}{\multicolumn{19}{|c|}{$\frac{\text { Variables }}{\text { Lags }}$}} \\
\hline & & & & & & & & & & & & & & & & & & \\
\hline Private Credit (t - 1) & $\begin{array}{c}1.0657^{* * *} \\
(0.0962)\end{array}$ & $\begin{array}{c}1.0853^{* * *} \\
(0.0607)\end{array}$ & $\begin{array}{c}0.9889^{* * *} \\
(0.0757)\end{array}$ & $\begin{array}{c}1.0532^{* * *} \\
(0.0627)\end{array}$ & \begin{tabular}{|c}
$0.9857^{* * *}$ \\
$(0.0798)$
\end{tabular} & $\begin{array}{c}1.1099 * * * \\
(0.0443)\end{array}$ & \begin{tabular}{|c}
$0.9345 * * *$ \\
$(0.1250)$
\end{tabular} & $\begin{array}{c}1.2090^{* * *} \\
(0.0465)\end{array}$ & \begin{tabular}{|c}
$0.9857^{* * *}$ \\
$(0.0770)$
\end{tabular} & $\begin{array}{c}1.1671^{* * *} \\
(0.0464)\end{array}$ & \begin{tabular}{|c}
$1.0125^{* * *}$ \\
$(0.0689)$
\end{tabular} & $\begin{array}{c}1.2032^{* * *} \\
(0.0382)\end{array}$ & $\begin{array}{c}1.0697 * * * \\
(0.1044)\end{array}$ & $\begin{array}{c}1.1516^{* * *} \\
(0.0433)\end{array}$ & $\begin{array}{c}1.0706^{* * *} \\
(0.0597)\end{array}$ & $\begin{array}{c}1.1463^{* * *} \\
(0.0443)\end{array}$ & $\begin{array}{c}1.1234^{* * *} \\
(0.0485)\end{array}$ & $\begin{array}{c}1.1612^{* * *} \\
(0.0353)\end{array}$ \\
\hline Private Credit ( $\mathrm{t}-2)$ & $\begin{array}{l}-0.1395 * * \\
(0.0700)\end{array}$ & $\begin{array}{l}-0.1483^{* *} \\
(0.0618)\end{array}$ & \begin{tabular}{|c|}
$-0.1397^{* *}$ \\
$(0.0690)$
\end{tabular} & $\begin{array}{c}-0.1475^{* *} \\
(0.0604)\end{array}$ & \begin{tabular}{|c|}
$-0.1726^{* * *}$ \\
$(0.0399)$
\end{tabular} & $\begin{array}{c}-0.1929 * * * \\
(0.0412)\end{array}$ & \begin{tabular}{|l|}
-0.0456 \\
$(0.0573)$
\end{tabular} & $\begin{array}{c}-0.1258^{* *} \\
(0.0486)\end{array}$ & $\begin{array}{l}-0.0651 \\
(0.0477)\end{array}$ & $\begin{array}{c}-0.1250^{* * * *} \\
(0.0477)\end{array}$ & $\begin{array}{c}-0.1119 * * * \\
(0.0357)\end{array}$ & $\begin{array}{c}-0.1695^{* * *} \\
(0.0379)\end{array}$ & $\begin{array}{l}-0.1285^{* *} \\
(0.0495)\end{array}$ & $\begin{array}{c}-0.1447^{* * * *} \\
(0.0421)\end{array}$ & \begin{tabular}{|c|}
$-0.1349 * * *$ \\
$(0.0412)$
\end{tabular} & $\begin{array}{c}-0.1574 * * * \\
(0.0399)\end{array}$ & $\begin{array}{c}-0.1618^{* * *} \\
(0.0317)\end{array}$ & $\begin{array}{c}-0.1686 * * * \\
(0.0314)\end{array}$ \\
\hline \multicolumn{19}{|l|}{$\begin{array}{l}\text { Policy variables } \\
\text { Macroeconomic variables }\end{array}$} \\
\hline \multirow[t]{2}{*}{$\begin{array}{l}\text { Macroeconomic variables } \\
\text { Growth }\end{array}$} & $0.1728^{* * *}$ & $0.1830 * * *$ & $\mid 0.1472^{* * * *}$ & $0.1656^{* * *}$ & -0.3233 & 0.0689 & $0.1565^{* * *}$ & $0.2843^{* * *}$ & $\mid 0.1798^{* * *}$ & $0.2211^{* * *}$ & -0.0249 & $0.2636^{*}$ & $0.1785^{* * *}$ & $0.2244^{* * *}$ & $0.1865^{* * * *}$ & $0.1881^{* * *}$ & 0.1814 & 0.1963 \\
\hline & $(0.0447)$ & $(0.0488)$ & $(0.0466)$ & $(0.0474)$ & $(0.3137)$ & $(0.2320)$ & $(0.0565)$ & $(0.0579)$ & $(0.0547)$ & $(0.0594)$ & $(0.1123)$ & $(0.1425)$ & $(0.0495)$ & $(0.0447)$ & $(0.0468)$ & $(0.0462)$ & $(0.1189)$ & $(0.1283)$ \\
\hline Inflation & $\begin{array}{l}-0.0203 \\
(0.0198)\end{array}$ & $\begin{array}{l}-0.0238 \\
(0.0172)\end{array}$ & $\begin{array}{l}-0.0097 \\
(0.0179)\end{array}$ & $\begin{array}{l}-0.0202 \\
(0.0191)\end{array}$ & $\begin{array}{c}0.0111 \\
(0.0321)\end{array}$ & $\begin{array}{c}0.0004 \\
(0.0188)\end{array}$ & $\begin{array}{l}-0.0181 \\
(0.0198)\end{array}$ & $\begin{array}{c}0.0006 \\
(0.0173)\end{array}$ & $\begin{array}{l}-0.0225 \\
(0.0190)\end{array}$ & $\begin{array}{l}-0.0130 \\
(0.0194)\end{array}$ & $\begin{array}{l}-0.0096 \\
(0.0175)\end{array}$ & $\begin{array}{c}0.0090 \\
(0.0172)\end{array}$ & $\begin{array}{l}-0.0189 \\
(0.0229)\end{array}$ & $\begin{array}{l}-0.0140 \\
0.0181)\end{array}$ & $\begin{array}{l}-0.0135 \\
(0.0211)\end{array}$ & $\begin{array}{l}-0.0172 \\
(0.0216)\end{array}$ & $\begin{array}{l}-0.0036 \\
(0.0214)\end{array}$ & $\begin{array}{c}0.0030 \\
(0.0193)\end{array}$ \\
\hline \multirow{2}{*}{ Remittance Inflows } & $\begin{array}{c}(0.0198) \\
0.0326\end{array}$ & $\begin{array}{l}(0.01 / 2) \\
-0.0074\end{array}$ & $\begin{array}{l}-0.0411 \\
\end{array}$ & 0.0782 & 0.0120 & $\begin{array}{c}(0.0188) \\
0.0402\end{array}$ & $\begin{array}{l}(0.0198) \\
-0.1054\end{array}$ & $\begin{array}{l}(0.0173) \\
0.0065\end{array}$ & $\begin{array}{c}(0.0190) \\
0.1631\end{array}$ & $\begin{array}{l}(0.0194) \\
-0.0227\end{array}$ & $\begin{array}{c}(0.0175) \\
0.1486\end{array}$ & $\begin{array}{l}(0.0172) \\
-0.0658\end{array}$ & $\begin{array}{l}(0.0229) \\
-0.0407\end{array}$ & $\begin{array}{l}(0.0181) \\
-0.0264\end{array}$ & $\begin{array}{l}(0.0211) \\
-0.2685^{*}\end{array}$ & $\begin{array}{l}(0.0216) \\
-0.0243\end{array}$ & $\begin{array}{l}(0.0214) \\
-0.2053\end{array}$ & $\begin{array}{l}(0.0193) \\
-0.0591\end{array}$ \\
\hline & $\begin{array}{l}0.0520 \\
(0.0576)\end{array}$ & $(0.0371)$ & $(0.1357)$ & $\begin{array}{l}(0.1092) \\
(0.02\end{array}$ & $(0.1802)$ & $\begin{array}{l}0.002 \\
(0.1263)\end{array}$ & $\begin{array}{l}-0.1154 \\
(0.1102)\end{array}$ & $\begin{array}{l}.00505 \\
(0.0505)\end{array}$ & $(0.2181)$ & $(0.1211)$ & $(0.2056)$ & $\begin{array}{l}-0.0008 \\
(0.1162)\end{array}$ & $\begin{array}{l}-0.0401 \\
(0.0646)\end{array}$ & $\begin{array}{l}-0.0224 \\
(0.0250)\end{array}$ & $\begin{array}{l}-0.2085 \\
(0.1550)\end{array}$ & $\begin{array}{l}-0.0243 \\
(0.1311)\end{array}$ & $\begin{array}{l}-0.2033 \\
(0.1629)\end{array}$ & $\begin{array}{l}-0.0591 \\
(0.1384)\end{array}$ \\
\hline Banking Crisis Dummy & $\begin{array}{c}-3.0218^{* * *} \\
(0.6741)\end{array}$ & $\begin{array}{c}-2.6811^{* * *} \\
(0.6229)\end{array}$ & $\begin{array}{c}-1.9922^{* *} \\
(0.7703)\end{array}$ & $\begin{array}{c}-2.4259 * * * \\
(0.6866)\end{array}$ & $\begin{array}{l}-2.5798^{*} \\
(1.3158)\end{array}$ & $\begin{array}{c}-3.2879 * * * \\
(0.8752)\end{array}$ & \begin{tabular}{|c|}
$-2.8993 * * *$ \\
$(0.8855)$
\end{tabular} & $\begin{array}{c}-4.2360 * * * \\
(0.9147)\end{array}$ & $\begin{array}{c}-2.1853^{* * *} \\
(0.7410)\end{array}$ & $\begin{array}{c}-3.7686^{* * *} \\
(0.7123)\end{array}$ & $\begin{array}{c}-2.4960^{* *} \\
(0.9839)\end{array}$ & $\begin{array}{c}-4.1877^{* * *} \\
(0.9183)\end{array}$ & $\begin{array}{c}-2.4591 * * * \\
(0.5704)\end{array}$ & $\begin{array}{c}-2.7541^{* * * *} \\
(0.5097)\end{array}$ & \begin{tabular}{|c}
$-1.9953^{* * * *}$ \\
$(0.6188)$
\end{tabular} & $\begin{array}{c}-2.4731^{* * *} \\
(0.5647)\end{array}$ & $\begin{array}{l}-1.9790^{* *} \\
(0.8662)\end{array}$ & $\begin{array}{c}-2.4245 * * * \\
(0.7433)\end{array}$ \\
\hline \multicolumn{19}{|l|}{ Openness variables } \\
\hline Financial Openness & $\begin{array}{c}0.0015 \\
(0.1465)\end{array}$ & $\begin{array}{c}0.0132 \\
(0.0978)\end{array}$ & $\begin{array}{c}0.8239 \\
(0.6445)\end{array}$ & $\begin{array}{l}-0.2612 \\
(0.2441)\end{array}$ & $\begin{array}{c}1.4414 \\
(0.9692)\end{array}$ & $\begin{array}{l}-0.0323 \\
(0.2340)\end{array}$ & $\begin{array}{c}0.1911 \\
(0.2089)\end{array}$ & $\begin{array}{l}0.0198 \\
(0.1438)\end{array}$ & $\begin{array}{c}0.4190 \\
(0.4823)\end{array}$ & $\begin{array}{c}0.3646 \\
(0.3351)\end{array}$ & $\begin{array}{c}0.5357 \\
(0.5355)\end{array}$ & $\begin{array}{l}0.4849 \\
(0.3178)\end{array}$ & $\begin{array}{c}0.1620 \\
(0.1865)\end{array}$ & $\begin{array}{c}0.0253 \\
(0.0952)\end{array}$ & $\begin{array}{c}0.3979 \\
(0.4596)\end{array}$ & $\begin{array}{c}0.0339 \\
(0.2078)\end{array}$ & $\begin{array}{c}0.3808 \\
(0.4261)\end{array}$ & $\begin{array}{c}0.2492 \\
(0.2252)\end{array}$ \\
\hline Trade Openness & $0.0263^{*}$ & $0.0230 * *$ & $0.0827^{* *}$ & $0.0458^{* * *}$ & 0.0326 & $0.0469 * *$ & $0.0774^{* *}$ & -0.0012 & 0.0762 & $0.0747 * * *$ & 0.0295 & $0.0748 * * *$ & $0.0319^{*}$ & $0.0139 * *$ & $0.0685 * *$ & $0.0308^{*}$ & -0.0299 & $0.0346 *$ \\
\hline & $(0.0153)$ & $(0.0110)$ & $(0.0415)$ & $(0.0168)$ & $(0.0764)$ & $(0.0232)$ & $(0.0344)$ & $(0.0130)$ & $(0.0546)$ & $(0.0253)$ & $(0.0535)$ & $(0.0249)$ & (0.0192) & $(0.0067)$ & $(0.0341)$ & $(0.0157)$ & $(0.0373)$ & $(0.0182)$ \\
\hline $\begin{array}{l}\text { Institutional vari } \\
\text { Polity Score }\end{array}$ & -0.0350 & -0.0162 & 0.0052 & -0.0530 & 0.0642 & -0.0171 & -0.0352 & 0.0223 & -0.0541 & 0.0218 & -0.0880 & 0.0199 & -0.0273 & 0.0156 & -0.0856 & -0.0320 & -0.1335 & -0.0283 \\
\hline & $(0.0373)$ & $(0.0290)$ & (0.1049) & $(0.0521)$ & $(0.1291)$ & $(0.0620)$ & $(0.0561)$ & $(0.0303)$ & $(0.1294)$ & $(0.0724)$ & $(0.1232)$ & $(0.0695)$ & $(0.0457)$ & (0.0191) & $(0.0910)$ & $(0.0556)$ & $(0.1047)$ & $(0.0643)$ \\
\hline Composite Risk Rating & $0.0647^{* *}$ & 0.0640 & $0.1218^{*}$ & $0.1409^{*}$ & $0.2540^{* * *}$ & $0.2066^{* *}$ & $0.1121^{* * *}$ & -0.0451 & $0.1056^{* *}$ & -0.0003 & $0.1274^{* *}$ & 0.0169 & $0.0844^{* * *}$ & 0.0112 & 0.0795 & 0.0319 & $0.1895 * *$ & 0.0847 \\
\hline & $(0.0290)$ & $(0.0394)$ & $(0.0624)$ & $(0.0750)$ & $(0.0845)$ & $(0.0910)$ & $(0.0387)$ & $(0.0286)$ & $(0.0439)$ & $(0.0550)$ & $(0.0546)$ & $(0.0507)$ & $(0.0316)$ & $(0.0226)$ & $(0.0657)$ & $(0.0560)$ & $(0.0743)$ & $(0.0516)$ \\
\hline Structural v & & & & & & & & & & & & & & & & & & \\
\hline Income Level & $\begin{array}{c}0.6636 \\
(0.5458)\end{array}$ & $\begin{array}{l}0.0480 \\
(0.1173)\end{array}$ & $\begin{array}{l}0.9629^{* *} \\
(0.4796)\end{array}$ & $\begin{array}{c}0.0863 \\
(0.2049)\end{array}$ & $\begin{array}{c}0.9400 \\
(0.6000)\end{array}$ & $\begin{array}{l}-0.1170 \\
(0.2076)\end{array}$ & $\begin{array}{c}0.8224 * * * \\
(0.2924)\end{array}$ & $\begin{array}{l}-0.0476 \\
(0.0513)\end{array}$ & $\begin{array}{c}0.7176^{* * *} \\
(0.2233)\end{array}$ & $\begin{array}{l}-0.0093 \\
(0.0528)\end{array}$ & $\begin{array}{c}0.7832 * * * \\
(0.2341)\end{array}$ & $\begin{array}{l}-0.0095 \\
(0.0531)\end{array}$ & $\begin{array}{l}0.4150^{* *} \\
(0.1906)\end{array}$ & $\begin{array}{c}0.0466 \\
(0.0304)\end{array}$ & $\begin{array}{c}0.3302 * * * \\
(0.1073)\end{array}$ & $\begin{array}{c}0.0740 \\
(0.0511)\end{array}$ & $\begin{array}{l}0.4072 * * * \\
(01258)\end{array}$ & $\begin{array}{c}0.0352 \\
(0.0464)\end{array}$ \\
\hline Population & 0.0459 & 0.0164 & 0.0738 & 0.0298 & $0.1401^{*}$ & 0.0239 & & -0.031 & 0.0129 & 0.004 & & 0.00 & & & 0.0066 & & 0.03 & \\
\hline & $(0.0313)$ & $(0.0135)$ & $(0.0510)$ & $(0.0193)$ & $(0.0731)$ & $(0.0213)$ & $(0.0892)$ & $(0.0197)$ & $(0.0809)$ & $(0.0205)$ & $(0.0666)$ & $(0.0198)$ & $(0.0314)$ & $(0.0063)$ & (0.0414) & $(0.0104)$ & $(0.0371)$ & $(0.0117)$ \\
\hline Population Density & 0.0018 & 0.0006 & 0.0067 & 0.0002 & 0.0053 & 0.0008 & 0.0065 & -0.0030 & 0.0003 & -0.0021 & 0.0032 & -0.0016 & 0.0009 & -0.0001 & 0.0069 & 0.0003 & -0.0005 & 0.0010 \\
\hline & $(0.0048)$ & $(0.0007)$ & $(0.0061)$ & $(0.0017)$ & $(0.0089)$ & $(0.0017)$ & $(0.0088)$ & $(0.0023)$ & $(0.0083)$ & $(0.0026)$ & $(0.0078)$ & $(0.0025)$ & $(0.0058)$ & $(0.0008)$ & $(0.0066)$ & $(0.0015)$ & $(0.0073)$ & $(0.0016)$ \\
\hline Age Dependency & 0.0078 & $-0.0363^{* *}$ & 0.0234 & $-0.0415 * *$ & 0.0400 & $-0.0384^{*}$ & -0.0058 & 0.0214 & 0.0018 & 0.0220 & -0.0087 & 0.0269 & 0.0321 & 0.0052 & 0.0342 & -0.0022 & $0.0516^{*}$ & 0.0128 \\
\hline ge elperitidy & $(0.0234)$ & $(0.0171)$ & $(0.0372)$ & $(0.0200)$ & $(0.0523)$ & $(0.0213)$ & $(0.0480)$ & $(0.0159)$ & $(0.0431)$ & $(0.0242)$ & $(0.0420)$ & $(0.0258)$ & $(0.0337)$ & $(0.0092)$ & (0.0304) & $(0.0143)$ & $(0.0290)$ & $(0.0174)$ \\
\hline Constant & & 0.8710 & & -3.3513 & & -6.8778 & & 0.4786 & & -3.2285 & & -6.0508 & & $\begin{array}{l}-0.5195 \\
\end{array}$ & & -1.2571 & & $-7.1145^{*}$ \\
\hline & & (1.7734) & & $(4.0028)$ & & $(4.23$ & & $(2.37$ & & $(4.69$ & & $(4.45$ & & $(1.73$ & & $(4.10$ & & (3.9581) \\
\hline Observatic & 1,537 & 1,614 & 1,537 & 1,614 & 1,535 & 1,612 & 1,766 & 1,878 & 1,766 & 1,878 & 1,869 & 1,981 & 2,141 & 2,255 & 2,141 & 2,255 & 2,145 & 2,259 \\
\hline $\mathrm{Ti}$ & YES & YES & YES & YES & YES & YES & YES & YES & YES & YES & YES & YES & YES & YES & YES & YES & YES & YES \\
\hline & 77 & 77 & 77 & 77 & 76 & 77 & 112 & 11 & 112 & 11 & 1 & 11 & 113 & 114 & 113 & 114 & 112 & 114 \\
\hline Number of instruments & 70 & 73 & 59 & 70 & 59 & 70 & 60 & 63 & 99 & 11 & 10 & 11 & 70 & 73 & 95 & 106 & 95 & 106 \\
\hline Hansen Test & 0.682 & 0.791 & 0.0332 & 0.0355 & 0.0552 & 0.127 & 0.469 & 0.426 & 0.784 & 0.297 & 0.373 & 0.301 & 0.0973 & 0.115 & 0.658 & 0.136 & 0.251 & 0.0926 \\
\hline $\operatorname{AR}(1)$ & $4.01 e-05$ & $5.93 \mathrm{e}-06$ & $3.85 \mathrm{e}-05$ & $7.14 \mathrm{e}-06$ & $2.60 \mathrm{e}-06$ & $1.33 \mathrm{e}-07$ & 0.0174 & 0.00131 & 0.00616 & 0.00128 & 0.00252 & 0.000244 & 0.00146 & 0.000159 & 0.00112 & 0.000172 & 0.000277 & $4.54 \mathrm{e}-05$ \\
\hline $\operatorname{AR}(2)$ & 0.374 & 0.389 & 0.401 & 0.394 & 0.314 & 0.771 & 0.135 & 0.410 & 0.183 & 0.469 & 0.333 & 0.681 & 0.436 & 0.425 & 0.427 & 0.529 & 0.928 & 0.961 \\
\hline
\end{tabular}


Table 6a. Summary Statistics and Correlations: Banking Sector Efficiency, Global sample, Annual Data (1,179 observations, 103 countries)

\begin{tabular}{|c|c|c|c|c|c|c|c|c|c|c|c|c|c|c|c|c|}
\hline \multicolumn{3}{|l|}{ Variable } & Abbreviation & & \multicolumn{2}{|l|}{ Source } & \multicolumn{4}{|c|}{ Unit of measurement } & Mean & $\begin{array}{r}\text { Overall } \\
\text { Standard } \\
\text { Deviation }\end{array}$ & $\begin{array}{l}\text { Between } \\
\text { Standard } \\
\text { Deviation }\end{array}$ & $\begin{array}{r}\text { Within } \\
\text { Standard } \\
\text { Deviation }\end{array}$ & Maximum & $\overline{\text { Minimum }}$ \\
\hline \multicolumn{3}{|c|}{ Net Interest Margin } & \multicolumn{2}{|l|}{ NIM } & \multicolumn{2}{|l|}{ FinStats } & \multicolumn{4}{|c|}{$\%$} & 4.64 & 3.13 & 2.66 & 1.68 & 30.29 & 0.00 \\
\hline \multirow{2}{*}{\multicolumn{3}{|c|}{$\begin{array}{l}\text { Growth Rate } \\
\text { Inflation }\end{array}$}} & \multirow{2}{*}{\multicolumn{2}{|c|}{$\begin{array}{l}\text { Growth } \\
\text { Inf }\end{array}$}} & & \multicolumn{4}{|c|}{$\%$ change in real GDP } & 2.78 & 4.02 & 1.91 & 3.53 & 30.34 & -16.59 \\
\hline & & & & & WEO & & \multirow{2}{*}{\multicolumn{4}{|c|}{$\begin{array}{l}\text { \% change in CPI } \\
\% \text { of GDP }\end{array}$}} & 6.57 & 9.72 & 6.56 & 7.45 & 168.60 & -8.24 \\
\hline \multicolumn{3}{|c|}{ Remittance Inflows } & \multicolumn{2}{|l|}{ Rem } & \multicolumn{2}{|l|}{ GFDD } & & & & & 3.16 & 5.08 & 4.85 & 1.64 & 34.50 & 0.00 \\
\hline \multirow{2}{*}{\multicolumn{3}{|c|}{$\begin{array}{l}\text { Banking Crisis } \\
\text { Financial Openness }\end{array}$}} & \multicolumn{2}{|l|}{ Crisis } & \multicolumn{2}{|c|}{ GFDD } & \multicolumn{4}{|c|}{ Dummy variable } & 0.10 & 0.31 & 0.13 & 0.28 & 1 & 0 \\
\hline & & & \multirow{2}{*}{\multicolumn{2}{|c|}{$\begin{array}{l}\text { FO } \\
\text { TO }\end{array}$}} & \multirow{2}{*}{\multicolumn{2}{|c|}{ Chinn \& Ito (2006) }} & \multicolumn{4}{|c|}{ Chinn - Ito Index } & 0.70 & 1.58 & 1.52 & 0.52 & 2.44 & -1.86 \\
\hline \multicolumn{3}{|c|}{$\begin{array}{l}\text { Financlal Upenness } \\
\text { Trade Openness }\end{array}$} & & & & & $\%$ of GDP & & & & 43.80 & 24.31 & 22.63 & 9.61 & 274.39 & 1.94 \\
\hline \multicolumn{3}{|c|}{ Polity Score } & Pol & & Polity IV Pro & & Polity Index & 10 to 10 & & & 5.73 & 5.33 & 5.57 & 1.48 & 10 & -10 \\
\hline Composit & k Rating & & Risk & & ICRG & & Risk Score, & o 100 & & & 70.78 & 9.12 & 8.64 & 3.35 & 92.38 & 32.80 \\
\hline Lerner Inc & f Banking S & ctor & Lerner & & GFDD & & Lerner Inde & & & & 0.24 & 0.14 & 0.10 & 0.10 & 0.82 & -1.61 \\
\hline Real GDP & capita & & GDPPC & & WDI & & Thousands & (constant & 5) US\$ & & 11.05 & 14.68 & 15.12 & 1.29 & 67.80 & 0.13 \\
\hline Populatio & & & Pop & & WDI & & Tens of mill & & & & 5.89 & 17.70 & 17.07 & 0.83 & 134.41 & 0.09 \\
\hline Populatio & nsity & & Den & & WDI & & People per & $\mathrm{km}$ of lar & & & 119.99 & 148.99 & 145.39 & 9.19 & 1174.33 & 1.54 \\
\hline Age Depe & cy Ratio & & Age & & WDI & & $\%$ of workin & age popul & & & 60.26 & 17.57 & 18.55 & 3.11 & 110.59 & 16.83 \\
\hline Correlatio & hatrix & & & & & & & & & & & & & & & \\
\hline & NIM & Growth & $\operatorname{lnf}$ & Rem & Crisis & FO & TO & Pol & Risk & Lerner & GDPPC & Pop & Den & Age & & \\
\hline NIM & 1.0000 & & & & & & & & & & & & & & & \\
\hline Growth & 0.0313 & 1.0000 & & & & & & & & & & & & & & \\
\hline $\operatorname{lnf}$ & 0.3819 & 0.0100 & 1.0000 & & & & & & & & & & & & & \\
\hline Rem & 0.1737 & 0.0453 & 0.0430 & 1.0000 & & & & & & & & & & & & \\
\hline Crisis & -0.1770 & -0.2488 & 0.0452 & -0.1065 & 1.0000 & & & & & & & & & & & \\
\hline FO & -0.2990 & -0.0835 & -0.2751 & -0.0793 & 0.1067 & 1.0000 & & & & & & & & & & \\
\hline TO & 0.0276 & 0.1094 & -0.0138 & 0.4816 & 0.0298 & 0.1133 & 1.0000 & & & & & & & & & \\
\hline Pol & -0.1604 & -0.0909 & -0.1300 & -0.1436 & 0.1439 & 0.4447 & 0.0408 & 1.0000 & & & & & & & & \\
\hline Risk & -0.5314 & 0.0704 & -0.3876 & -0.3356 & 0.0600 & 0.5639 & -0.0061 & 0.3540 & 1.0000 & & & & & & & \\
\hline Lerner & 0.1532 & 0.1539 & -0.0231 & 0.0327 & -0.1601 & -0.1361 & 0.0680 & -0.2611 & -0.0840 & 1.0000 & & & & & & \\
\hline GDPPC & -0.5149 & -0.1594 & -0.2584 & -0.3271 & 0.2047 & 0.5850 & -0.1013 & 0.4247 & 0.7572 & -0.1598 & 1.0000 & & & & & \\
\hline Pop & -0.0993 & 0.1681 & -0.0194 & -0.0716 & 0.0022 & -0.1978 & -0.2079 & -0.1329 & 0.0013 & 0.0446 & -0.0794 & 1.0000 & & & & \\
\hline Den & -0.1862 & 0.0200 & -0.0548 & 0.2371 & 0.0165 & 0.0062 & 0.0292 & 0.0880 & 0.0205 & -0.0404 & 0.0811 & 0.1874 & 1.0000 & & & \\
\hline Age & 0.4074 & -0.1498 & 0.0759 & 0.1297 & -0.1721 & -0.3573 & -0.1028 & -0.3253 & -0.5631 & 0.1554 & -0.4250 & -0.1003 & -0.1205 & 1.0000 & & \\
\hline
\end{tabular}


Table 6b. Determinants of Banking Sector Efficiency

\begin{tabular}{|c|c|c|c|c|c|c|c|c|}
\hline \multirow[b]{2}{*}{ Variables } & \multirow[b]{2}{*}{ OLS } & \multirow[b]{2}{*}{$\mathrm{FE}$} & \multicolumn{2}{|c|}{ Exogenous } & \multicolumn{2}{|c|}{ Predetermined } & \multicolumn{2}{|c|}{ Endogenous } \\
\hline & & & D GMM & S GMM & D GMM & S GMM & D GMM & SGMM \\
\hline \multicolumn{9}{|l|}{ Lags } \\
\hline Net Interest Margin $(t-1)$ & $\begin{array}{c}0.6177^{* * *} \\
(0.0211)\end{array}$ & $\begin{array}{c}0.2157^{* * *} \\
(0.0284)\end{array}$ & $\begin{array}{c}0.3136^{* * *} \\
(0.0893)\end{array}$ & $\begin{array}{c}0.2773 * * * \\
(0.0794)\end{array}$ & $\begin{array}{c}0.2554^{* *} \\
(0.1010)\end{array}$ & $\begin{array}{c}0.3280^{* * *} \\
(0.0845)\end{array}$ & $\begin{array}{c}0.2590 * * * \\
(0.0780)\end{array}$ & $\begin{array}{c}0.3457^{* * *} \\
(0.0678)\end{array}$ \\
\hline \multicolumn{9}{|l|}{ Policy variables } \\
\hline \multicolumn{9}{|l|}{ Macroeconomic variables } \\
\hline Growth & $\begin{array}{c}0.0084 \\
(0.0152)\end{array}$ & $\begin{array}{l}-0.0165 \\
(0.0162)\end{array}$ & $\begin{array}{c}-0.0274 * \\
(0.0144)\end{array}$ & $\begin{array}{l}-0.0117 \\
(0.0178)\end{array}$ & $\begin{array}{c}-0.0470 * * * \\
(0.0179)\end{array}$ & $\begin{array}{c}-0.0299 * \\
(0.0164)\end{array}$ & $\begin{array}{l}-0.0197 \\
(0.0484)\end{array}$ & $\begin{array}{l}-0.0278 \\
(0.0505)\end{array}$ \\
\hline Inflation & $\begin{array}{c}0.0335 * * * \\
(0.0066)\end{array}$ & $\begin{array}{c}0.0265 * * * \\
(0.0071)\end{array}$ & $\begin{array}{c}0.0268^{* * * *} \\
(0.0067)\end{array}$ & $\begin{array}{c}0.0513^{* * *} \\
(0.0116)\end{array}$ & $\begin{array}{c}0.0174 * * \\
(0.0087)\end{array}$ & $\begin{array}{c}0.0222^{* *} \\
(0.0090)\end{array}$ & $\begin{array}{c}0.0246 \\
(0.0159)\end{array}$ & $\begin{array}{c}0.0112 \\
(0.0151)\end{array}$ \\
\hline Remittance Inflows & $\begin{array}{c}0.0152 \\
(0.0128)\end{array}$ & $\begin{array}{c}-0.0324 \\
(0.0309)\end{array}$ & $\begin{array}{l}-0.0077 \\
(0.0310)\end{array}$ & $\begin{array}{c}0.0190 \\
(0.0253)\end{array}$ & $\begin{array}{l}-0.1217 \\
(0.0767)\end{array}$ & $\begin{array}{c}0.0079 \\
(0.0459)\end{array}$ & $\begin{array}{c}-0.1410^{*} \\
(0.0823)\end{array}$ & $\begin{array}{c}0.0255 \\
(0.0587)\end{array}$ \\
\hline Banking Crisis Dummy & $\begin{array}{l}-0.1240 \\
(0.1898)\end{array}$ & $\begin{array}{c}0.0489 \\
(0.1964)\end{array}$ & $\begin{array}{c}0.0148 \\
(0.1695)\end{array}$ & $\begin{array}{c}-0.3120 \\
(0.2009)\end{array}$ & $\begin{array}{l}-0.5295 \\
(0.3495)\end{array}$ & $\begin{array}{c}-0.6011^{* *} \\
(0.2615)\end{array}$ & $\begin{array}{l}-0.3893 \\
(0.5198)\end{array}$ & $\begin{array}{c}-0.8066^{* *} \\
(0.3819)\end{array}$ \\
\hline \multicolumn{9}{|l|}{ Openness variables } \\
\hline Financial Openness & $\begin{array}{c}0.0426 \\
(0.0432)\end{array}$ & $\begin{array}{c}0.2420^{* *} \\
(0.0990)\end{array}$ & $\begin{array}{c}0.1583 \\
(0.1375)\end{array}$ & $\begin{array}{c}0.0772 \\
(0.0852)\end{array}$ & $\begin{array}{c}-0.2575 \\
(0.3533)\end{array}$ & $\begin{array}{c}0.0685 \\
(0.2020)\end{array}$ & $\begin{array}{c}0.0523 \\
(0.4626)\end{array}$ & $\begin{array}{c}0.1578 \\
(0.2439)\end{array}$ \\
\hline Trade Openness & $\begin{array}{l}-0.0031 \\
(0.0025)\end{array}$ & $\begin{array}{c}-0.0149 * * * \\
(0.0053)\end{array}$ & $\begin{array}{c}-0.0132^{* * *} \\
(0.0043)\end{array}$ & $\begin{array}{c}-0.0050 \\
(0.0047)\end{array}$ & $\begin{array}{c}-0.0203 \\
(0.0204)\end{array}$ & $\begin{array}{l}-0.0007 \\
(0.0062)\end{array}$ & $\begin{array}{l}-0.0208 \\
(0.0194)\end{array}$ & $\begin{array}{c}-0.0093 \\
(0.0064)\end{array}$ \\
\hline \multicolumn{9}{|l|}{ Institutional variables } \\
\hline Polity Score & $\begin{array}{c}0.0316^{* * *} \\
(0.0113)\end{array}$ & $\begin{array}{l}0.0582^{*} \\
(0.0349)\end{array}$ & $\begin{array}{c}0.0167 \\
(0.0308)\end{array}$ & $\begin{array}{c}0.0464^{* *} \\
(0.0207)\end{array}$ & $\begin{array}{c}-0.1315 \\
(0.1021)\end{array}$ & $\begin{array}{c}0.0137 \\
(0.0632)\end{array}$ & $\begin{array}{l}-0.0386 \\
(0.1239)\end{array}$ & $\begin{array}{c}0.0670 \\
(0.0566)\end{array}$ \\
\hline Composite Risk Rating & $\begin{array}{c}-0.0195^{*} \\
(0.0110)\end{array}$ & $\begin{array}{c}0.0223 \\
(0.0167)\end{array}$ & $\begin{array}{c}0.0235 \\
(0.0177)\end{array}$ & $\begin{array}{l}-0.0305 \\
(0.0239)\end{array}$ & $\begin{array}{l}-0.0440 \\
(0.0380)\end{array}$ & $\begin{array}{c}-0.0711^{* *} \\
(0.0338)\end{array}$ & $\begin{array}{c}-0.0781 \\
(0.0514)\end{array}$ & $\begin{array}{c}-0.1138^{* * *} \\
(0.0393)\end{array}$ \\
\hline \multicolumn{9}{|l|}{ Market power } \\
\hline Lerner Index & $\begin{array}{c}1.1533^{* * *} \\
(0.3974)\end{array}$ & $\begin{array}{c}2.1535^{* * *} \\
(0.4797)\end{array}$ & $\begin{array}{c}1.5019 * * \\
(0.7571)\end{array}$ & $\begin{array}{c}1.5769 * * \\
(0.6529)\end{array}$ & $\begin{array}{l}1.3452^{*} \\
(0.8007)\end{array}$ & $\begin{array}{l}1.4600^{*} \\
(0.8404)\end{array}$ & $\begin{array}{c}1.2580 \\
(1.1717)\end{array}$ & $\begin{array}{c}1.2690 \\
(1.1144)\end{array}$ \\
\hline \multicolumn{9}{|l|}{ Structural variables } \\
\hline Income Level & $\begin{array}{c}-0.0214 * * * \\
(0.0062)\end{array}$ & $\begin{array}{c}0.0484 \\
(0.0523)\end{array}$ & $\begin{array}{c}0.0512 \\
(0.0363)\end{array}$ & $\begin{array}{c}-0.0491 * * * \\
(0.0122)\end{array}$ & $\begin{array}{c}0.0099 \\
(0.0485)\end{array}$ & $\begin{array}{c}-0.0298 \\
(0.0225)\end{array}$ & $\begin{array}{c}-0.0182 \\
(0.0775)\end{array}$ & $\begin{array}{l}-0.0254 \\
(0.0203)\end{array}$ \\
\hline Population & $\begin{array}{c}-0.0033 \\
(0.0031)\end{array}$ & $\begin{array}{c}0.0406 \\
(0.0653)\end{array}$ & $\begin{array}{c}0.0568 \\
(0.0603)\end{array}$ & $\begin{array}{c}-0.0066 \\
(0.0044)\end{array}$ & $\begin{array}{c}0.0541 \\
(0.0633)\end{array}$ & $\begin{array}{c}-0.0054 \\
(0.0048)\end{array}$ & $\begin{array}{c}0.0561 \\
(0.0672)\end{array}$ & $\begin{array}{c}-0.0037 \\
(0.0066)\end{array}$ \\
\hline Population Density & $\begin{array}{c}-0.0008^{* *} \\
(0.0004)\end{array}$ & $\begin{array}{c}0.0175 * * * \\
(0.0066)\end{array}$ & $\begin{array}{l}0.0131^{*} \\
(0.0067)\end{array}$ & $\begin{array}{c}-0.0017^{* * *} \\
(0.0006)\end{array}$ & $\begin{array}{l}0.0131^{*} \\
(0.0071)\end{array}$ & $\begin{array}{c}-0.0017^{* *} \\
(0.0008)\end{array}$ & $\begin{array}{l}0.0146^{*} \\
(0.0078)\end{array}$ & $\begin{array}{c}-0.0020^{* *} \\
(0.0009)\end{array}$ \\
\hline Age Dependency & $\begin{array}{c}0.0147^{* * *} \\
(0.0039)\end{array}$ & $\begin{array}{l}0.0362^{*} \\
(0.0215)\end{array}$ & $\begin{array}{c}0.0201 \\
(0.0201)\end{array}$ & $\begin{array}{c}0.0239 * * \\
(0.0094)\end{array}$ & $\begin{array}{c}0.0004 \\
(0.0251)\end{array}$ & $\begin{array}{c}0.0129 \\
(0.0130)\end{array}$ & $\begin{array}{c}0.0021 \\
(0.0267)\end{array}$ & $\begin{array}{c}0.0074 \\
(0.0133)\end{array}$ \\
\hline Constant & $\begin{array}{l}1.6893^{*} \\
(0.9096) \\
\end{array}$ & $\begin{array}{l}-3.1789 \\
(2.1707) \\
\end{array}$ & & $\begin{array}{l}3.9970^{*} \\
(2.1072) \\
\end{array}$ & & $\begin{array}{l}7.5215^{* *} \\
(3.1407) \\
\end{array}$ & & $\begin{array}{c}10.3866 * * * \\
(3.3690) \\
\end{array}$ \\
\hline $\begin{array}{l}\text { Observations } \\
\text { R-squared }\end{array}$ & $\begin{array}{c}1,178 \\
0.6988\end{array}$ & $\begin{array}{c}1,178 \\
0.2009\end{array}$ & 1,136 & 1,239 & 1,136 & 1,239 & 1,075 & 1,178 \\
\hline Time Dummies & YES & YES & YES & YES & YES & YES & YES & YES \\
\hline Number of countries & & 103 & 102 & 103 & 102 & 103 & 102 & 103 \\
\hline Number of instruments & & & 39 & 41 & 87 & 98 & 86 & 97 \\
\hline Hansen Test & & & 0.00506 & 0.0233 & 0.194 & 0.292 & 0.330 & 0.200 \\
\hline$A R(1)$ & & & 0.00855 & 0.00919 & 0.0166 & 0.00901 & 0.0218 & 0.0104 \\
\hline$A R(2)$ & & & 0.880 & 0.657 & 0.752 & 0.923 & 0.815 & 0.850 \\
\hline
\end{tabular}

Standard errors in parentheses

*** $p<0.01, * * p<0.05, * p<0.1$ 
Table 6c. Robustness Checks: Determinants of Banking Sector Efficiency

\begin{tabular}{|c|c|c|c|c|c|c|c|c|c|c|c|c|c|c|c|c|c|c|}
\hline \multirow[b]{3}{*}{ Variables } & \multicolumn{6}{|c|}{ Developing Countries } & \multicolumn{6}{|c|}{ Pre-GFC (upto 2007) } & \multicolumn{6}{|c|}{ 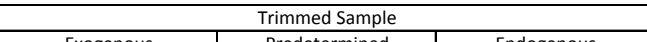 } \\
\hline & \multicolumn{2}{|c|}{$\begin{array}{l}\text { Exogenous } \\
\end{array}$} & \multicolumn{2}{|c|}{ Predetermined } & \multicolumn{2}{|c|}{ Endogenous } & \multicolumn{2}{|c|}{ Exogenous } & \multicolumn{2}{|c|}{ Predetermined } & \multicolumn{2}{|c|}{ Endogenous } & \multicolumn{2}{|c|}{ Exogenous } & \multicolumn{2}{|c|}{ Predetermined } & \multicolumn{2}{|c|}{ Endogenous } \\
\hline \multirow{2}{*}{\multicolumn{19}{|c|}{ Lags }} \\
\hline & & & & & & & & & & & & & & & & & & \\
\hline Net Interest Margin ( $\mathrm{t}$ - 1) & $\begin{array}{c}0.3345^{* * *} \\
(0.1104)\end{array}$ & $\begin{array}{c}0.3461^{* * *} \\
(0.1230)\end{array}$ & $\begin{array}{l}0.2697^{*} \\
(0.1568)\end{array}$ & $\begin{array}{c}0.3768 * * * \\
(0.1220)\end{array}$ & $\begin{array}{c}0.2684^{* *} \\
(0.1285)\end{array}$ & $\begin{array}{c}0.3779 * * * \\
(0.0730)\end{array}$ & $\begin{array}{c}0.3377^{* * *} \\
(0.1073)\end{array}$ & $\begin{array}{c}0.1375 * * * \\
(0.0470)\end{array}$ & $\begin{array}{l}0.2289 * * \\
(0.1145)\end{array}$ & $\begin{array}{c}0.2463^{* * *} \\
(0.0607)\end{array}$ & $\begin{array}{c}0.2463^{* * *} \\
(0.0901)\end{array}$ & $\begin{array}{c}0.2858^{* * *} \\
(0.0676)\end{array}$ & $\begin{array}{c}0.2836^{* * *} \\
(0.0814)\end{array}$ & $\begin{array}{c}0.2951^{* * *} \\
(0.0733)\end{array}$ & \begin{tabular}{|c|}
$0.2979 * * *$ \\
$(0.0835)$
\end{tabular} & $\begin{array}{c}0.4269 * * * \\
(0.0666)\end{array}$ & $\begin{array}{c}0.2991 * * * \\
(0.0746)\end{array}$ & $\begin{array}{c}0.4167 * * * \\
(0.0637)\end{array}$ \\
\hline \multicolumn{19}{|l|}{$\begin{array}{l}\text { Policy variables } \\
\text { Macroeconomic variables }\end{array}$} \\
\hline \multirow[t]{2}{*}{ Growth } & $-0.0293^{*}$ & -0.0138 & $-0.0623^{* * *}$ & $-0.0387^{* *}$ & -0.0766 & -0.0526 & $-0.0424 * *$ & -0.0437 & $-0.0879 * * *$ & -0.0467 & $-0.0741^{*}$ & -0.0500 & -0.0202 & 0.0033 & $-0.0291^{*}$ & -0.0075 & 0.0099 & 0.0218 \\
\hline & $(0.0163)$ & $(0.0176)$ & $(0.0203)$ & $(0.0178)$ & $(0.0765)$ & $(0.0751)$ & $(0.0205)$ & $(0.0291)$ & $(0.0290)$ & $(0.0287)$ & $(0.0388)$ & $(0.0690)$ & $(0.0143)$ & $(0.0152)$ & $(0.0166)$ & $(0.0157)$ & $(0.0387)$ & $(0.0349)$ \\
\hline \multirow[t]{2}{*}{ Inflation } & $0.0314^{* * *}$ & $0.0530^{* * *}$ & $0.0246^{* *}$ & $0.0268^{* *}$ & 0.0366 & 0.0285 & $0.0269 * * *$ & $0.0594^{* * *}$ & 0.0221 & $0.0297 * *$ & 0.0214 & 0.0214 & $0.0147^{*}$ & $0.0340^{* * *}$ & 0.0025 & 0.0075 & 0.0323 & $0.0364^{*}$ \\
\hline & $(0.0094)$ & $(0.0115)$ & $(0.0098)$ & $(0.0107)$ & $(0.0225)$ & $(0.0205)$ & $(0.0100)$ & $(0.0172)$ & $(0.0134)$ & $(0.0129)$ & $(0.0150)$ & $(0.0165)$ & $(0.0081)$ & $(0.0110)$ & $(0.0074)$ & $(0.0085)$ & $(0.0221)$ & $(0.0201)$ \\
\hline \multirow[t]{2}{*}{ Remittance Inflows } & -0.0026 & -0.0065 & -0.1918 & -0.0171 & -0.0182 & 0.0304 & -0.0015 & 0.0092 & -0.1184 & 0.0094 & -0.0964 & 0.0497 & -0.0324 & 0.0235 & -0.0718 & 0.0155 & -0.0836 & 0.0170 \\
\hline & $(0.0310)$ & $(0.0271)$ & $(0.1490)$ & $(0.0514)$ & $(0.0988)$ & $(0.0608)$ & $(0.0481)$ & $(0.0351)$ & $(0.1307)$ & $(0.0542)$ & $(0.1242)$ & $(0.0532)$ & $(0.0311)$ & $(0.0249)$ & $(0.05$ & $(0.0363)$ & $(0.0519)$ & $(0.0442)$ \\
\hline Banking Crisis Dummy & -0.1932 & $-0.7065^{*}$ & -0.4162 & -0.7824 & -0.3436 & -0.5997 & -0.1963 & $-0.6712^{*}$ & -0.5333 & -0.3563 & -0.7237 & -0.4454 & -0.0794 & -0.2758 & -0.5504 & -0.2592 & -0.4903 & -0.4365 \\
\hline & $(0.3519)$ & (0.3953) & (0.6915) & $(0.4868)$ & $(1.2158)$ & $(0.7367)$ & (0.3736) & $(0.3670)$ & $(0.4666)$ & $(0.4480)$ & (0.6119) & $(0.5426)$ & (0.1529) & $(0.1753)$ & $(0.3671)$ & $(0.2197)$ & $(0.4650)$ & $(0.2997)$ \\
\hline Openness variables & & & & & & & & & & & & & & & & & & \\
\hline Financial Openness & 0.2451 & $0.1885^{* *}$ & -0.2976 & 0.1671 & 0.0077 & 0.2394 & 0.2122 & 0.0637 & $\begin{array}{l}-0.0347 \\
-0.3356)\end{array}$ & $0.5238^{* *}$ & 0.2272 & 0.4063 & -0.0246 & 0.0750 & $\begin{array}{l}-0.2781 \\
-02993)\end{array}$ & 0.0065 & $\begin{array}{l}0.0600 \\
0.31844\end{array}$ & $\begin{array}{l}0.0895 \\
0.01728)\end{array}$ \\
\hline & & $(0.0860)$ & (0.6081) & $(0.2448)$ & $(0.5569)$ & (0.2798) & $(0.1728)$ & $(0.1375)$ & $(0.3356)$ & $(0.2482)$ & $(0.3844)$ & $(0.2770)$ & $(0.0861)$ & $(0.0735)$ & (0.2993) & $(0.1662)$ & $(0.3184)$ & (0.1728) \\
\hline Trade Openness & $\begin{array}{l}-0.0121^{* *} \\
(0.053)\end{array}$ & $\begin{array}{l}-0.0030 \\
(0.0056)\end{array}$ & -0.0238 & -0.0007 & -0.0151 & -0.0099 & -0.0167 & -0.0003 & -0.0103 & 0.0078 & $-0.0771^{*}$ & -0.0133 & $-0.0072^{* *}$ & -0.0033 & -0.0158 & -0.0045 & -0.0193 & $-0.0102^{* *}$ \\
\hline institutional $v$ & $(0.0053)$ & $(0.0056)$ & $(0.0238)$ & $(0.0074)$ & $(0.0214)$ & $(0.0069)$ & $(0.0178)$ & $(0.0092)$ & $(0.0745)$ & (0.0159) & $(0.0456)$ & $(0.0188)$ & $(0.0036)$ & $(0.0041)$ & $(0.0151)$ & $(0.0043)$ & $(0.0178)$ & $(0.0044)$ \\
\hline Institutional variabl & & & & & & & & & & & & & & & & & & \\
\hline Polity Score & 0.0293 & $0.0617^{* *}$ & -0.1217 & 0.0538 & 0.1160 & 0.0752 & 0.0382 & $0.0687^{* *}$ & -0.0568 & 0.0323 & 0.0999 & 0.0741 & 0.0017 & $0.0403^{* *}$ & -0.0608 & 0.0328 & -0.0127 & $0.0809^{*}$ \\
\hline Composite Risk Rating & $\begin{array}{l}(0.0351) \\
0.0184\end{array}$ & $(0.0277)$ & $(0.1389)$ & $(0.0536)$ & $(0.1671)$ & $(0.0515)$ & $(0.0387)$ & $(0.0273)$ & $(0.0950)$ & $(0.0649)$ & $(0.1463)$ & $\begin{array}{l}(0.0655) \\
-0.1137 * *\end{array}$ & $(0.0269)$ & $(0.0185)$ & $(0.0708)$ & $(0.0485)$ & $(0.0994)$ & $(0.0419)$ \\
\hline Composite Kisk Kating & 0.0184 & -0.0282 & -0.0194 & -0.0858 & -0.0690 & -0.0945 & $0.0444^{*}$ & -0.0400 & -0.0095 & -0.0961 & -0.0646 & -0.1137 & 0.0219 & -0.0185 & -0.0293 & -0.0360 & .0491 & -0.0668 \\
\hline Market power & $(0.0217)$ & $(0.0272)$ & $(0.0498)$ & $(0.0552)$ & $(0.0734)$ & $(0.0577)$ & $(0.0228)$ & $(0.0343)$ & $(0.0531)$ & $(0.0506)$ & $(0.0572)$ & $(0.0491)$ & $(0.0137)$ & $(0.0178)$ & $(0.0312)$ & $(0.0310)$ & $(0.0372)$ & $(0.0302)$ \\
\hline Lerner Index & $2.7053^{* *}$ & $1.8011^{*}$ & $2.2893^{*}$ & $2.3984^{* *}$ & $4.5940^{* * *}$ & 3.1393** $\quad>$ & 0.8193 & $2.0219^{* *}$ & 16691 & 1.8721 & 1.7976 & 0.8747 & $0.9703^{* *}$ & $0.9089 *$ & 0.6910 & 0.8779 & 0.5856 & 0.6775 \\
\hline & $(1.0381)$ & (0.9444) & (1.1944) & $(1.1263)$ & $(1.6915)$ & $(1.4282)$ & (0.9398) & $(0.8999)$ & $(1.0850)$ & $(1.3148)$ & $(1.2762)$ & (1.4295) & $(0.4546)$ & $(0.4592)$ & $(0.5437)$ & $(0.5314)$ & (1.2059) & $(0.8508)$ \\
\hline $\begin{array}{l}\text { Structural variables } \\
\text { Income Level }\end{array}$ & -0.0803 & -0.1458 & -0.1319 & -0.0844 & -0.1046 & -0.0896 & 0.0391 & $-0.0631^{* * *}$ & -0.0110 & $-0.0568^{* *}$ & -0.0477 & $-0.0490^{* *}$ & -0.0200 & $-0.0517 * * *$ & -0.0320 & $-0.0363^{* *} *$ & -0.0361 & $-0.0317^{*}>0$ \\
\hline & & & & & & & & & & & & & & & & & & \\
\hline & $(0.2189)$ & $(0.0962)$ & $(0.4640)$ & $(0.1452)$ & (0.4132) & $(0.1275)$ & $(0.0742)$ & $(0.0200)$ & $(0.0895)$ & $(0.0248)$ & $(0.0936)$ & $(0.0232)$ & (0.0358) & $(0.0128)$ & (0.0446) & $(0.0170)$ & $(0.0591)$ & $(0.0163)$ \\
\hline Population & 0.0533 & -0.0086 & 0.04 & -0.00 & 0.0681 & -0.0038 & & -0.0083 & 0.0353 & 0.00 & 0.10 & -0.00 & 0.0165 & -0.0053 & 0.0241 & -0.0054 & 0.0237 & -0.0047 \\
\hline & $(0.0627)$ & $(0.0057)$ & $(0.076)$ & $(0.0066)$ & $(0.0800)$ & $(0.0080)$ & $(0.09$ & $(0.0050)$ & $(0.1122)$ & $(0.0068)$ & $(0.1004)$ & $(0.008$ & $(0.0534)$ & $(0.0036)$ & (0.0526) & $(0.0043)$ & (0.0538) & $(0.0059)$ \\
\hline Population Density & $0.0126^{* *}$ & $-0.0015^{*}$ & 0.0145 & -0.0016 & 0.0128 & $-0.0022^{* *}$ & 0.0088 & $-0.0030^{* * *}$ & 0.0098 & $-0.0028 * * *$ & -0.0017 & $-0.0030^{* * *}$ & $0.0154^{* *}$ & $-0.0015^{* * *}$ & 0.0135 & $-0.0013^{* *}$ & 0.0121 & $-0.0015 *$ \\
\hline & $(0.0063)$ & $(0.0008)$ & $(0.0102$ & $(0.0010)$ & $(0.0105)$ & $(0.0010)$ & (0.0095) & $(0.0008)$ & $(0.0111)$ & $(0.0008)$ & $(0.0141)$ & $(0.0009)$ & $(0.0076)$ & $(0.0005)$ & $(0.0084)$ & $(0.0006)$ & $(0.0083)$ & $(0.0007)$ \\
\hline Age Dependency & 0.0061 & 0.0111 & -0.0116 & 0.0026 & 0.0407 & 0.0003 & 0.0304 & $0.0237^{*}$ & -0.0146 & 0.0151 & -0.0132 & 0.0071 & 0.0216 & $0.0216^{* * *}$ & 0.0102 & 0.0120 & 0.0193 & 0.0114 \\
\hline & $(0.0313)$ & $(0.0100)$ & $(0.0395)$ & $(0.0115)$ & $(0.0408)$ & $(0.0140)$ & $(0.0422)$ & $(0.0134)$ & $(0.0712)$ & $(0.0194)$ & $(0.0518)$ & $(0.0194)$ & $(0.0194)$ & $(0.0080)$ & $(0.0222)$ & $(0.0097)$ & $(0.0245)$ & $(0.0091)$ \\
\hline Constant & & $4.7166^{*}$ & & 8.9274 & & $9.4235 * *$ & & $5.6333^{*}$ & & $8.9129^{*}$ & & $12.0426 * *$ & & $3.0626^{*}$ & & 4.4508 & & $6.3989 * *$ \\
\hline & & $(2.5254)$ & & (4.7115) & & (4.6155) & & $(2.9055)$ & & $(4.7011)$ & & $(4.8608)$ & & (1.6151) & & (2.7150) & & (2.5925) \\
\hline & 71 & 777 & 71 & 777 & 67 & 735 & 70 & 798 & 70 & 798 & 70 & 809 & 1,06 & 1,163 & 1,060 & 1,163 & 1,002 & 1,105 \\
\hline & YES & YES & YE & & YE & YE & YE & $\mathrm{Y}$ & YES & YE & YES & & & & YES & & & \\
\hline $\mathrm{Nu}$ & 65 & 65 & 65 & 65 & 65 & 65 & 98 & 98 & 98 & 98 & 98 & 100 & 102 & 103 & 102 & 103 & 102 & 103 \\
\hline Number of instruments & 39 & 41 & 47 & 58 & 46 & 57 & 29 & 31 & 82 & 93 & 82 & 93 & 39 & 41 & 87 & 98 & 86 & 97 \\
\hline Hansen Test & 0.168 & 0.323 & 0.391 & 0.172 & 0.169 & 0.145 & 0.0270 & 0.0552 & 0.341 & 0.451 & 0.658 & 0.238 & 0.313 & 0.186 & 0.298 & 0.480 & 0.414 & 0.276 \\
\hline $\mathrm{AR}(1)$ & $6.84 \mathrm{e}-05$ & & 0.00173 & & 0.00119 & $5.81 \mathrm{e}-0 \mathrm{e}$ & 0.0546 & 0.0482 & 0.0671 & 0.0302 & 0.0526 & 0.0144 & $1.94 \mathrm{e}-06$ & $1.24 \mathrm{e}-07$ & $1.14 \mathrm{e}-06$ & $5.97 \mathrm{e}-08$ & 4.03e-08 & $3.59 \mathrm{e}-09$ \\
\hline $\operatorname{AR}(2)$ & 0.513 & 0.487 & 0.517 & 0.565 & 0.746 & 0.865 & 0.417 & 0.176 & 0.297 & 0.326 & 0.534 & 0.619 & 0.563 & 0.532 & 0.451 & 0.200 & 0.735 & 0.395 \\
\hline
\end{tabular}


Table 7a. Summary Statistics and Correlations: Banking Sector Stability, Global Sample, Annual Data (930 observations, 85 countries)

\begin{tabular}{|c|c|c|c|c|c|c|c|c|c|c|c|c|c|c|c|c|}
\hline \multicolumn{3}{|l|}{ Variable } & Abbreviation & & \multicolumn{2}{|l|}{ Source } & \multicolumn{4}{|c|}{ Unit of measurement } & Mean & $\begin{array}{r}\text { Overall } \\
\text { Standard } \\
\text { Deviation }\end{array}$ & $\begin{array}{l}\text { Between } \\
\text { Standard } \\
\text { Deviation }\end{array}$ & $\begin{array}{r}\text { Within } \\
\text { Standard } \\
\text { Deviation }\end{array}$ & Maximum & Minimum \\
\hline \multicolumn{3}{|c|}{ Non Performing Loans } & \multicolumn{2}{|l|}{ NPL } & \multicolumn{2}{|l|}{ FinStats } & \multicolumn{4}{|c|}{ \% of Total Gross Loans } & 7.26 & 7.49 & 5.96 & 5.22 & 48.60 & 0.10 \\
\hline \multirow{2}{*}{\multicolumn{3}{|c|}{$\begin{array}{l}\text { Growth Rate } \\
\text { Inflation }\end{array}$}} & \multirow{2}{*}{\multicolumn{2}{|c|}{$\begin{array}{l}\text { Growth } \\
\text { Inf }\end{array}$}} & \multicolumn{2}{|l|}{ WDI } & \multicolumn{4}{|c|}{$\%$ change in real GDP } & 2.78 & 4.03 & 1.90 & 3.58 & 30.34 & -16.59 \\
\hline & & & & & \multirow{2}{*}{\multicolumn{2}{|c|}{$\begin{array}{l}\text { WEO } \\
\text { GFDD }\end{array}$}} & \multicolumn{4}{|c|}{ \% change in CPI } & 6.32 & 9.87 & 5.94 & 7.71 & 168.60 & -3.66 \\
\hline \multicolumn{3}{|c|}{ Remittance Inflows } & \multicolumn{2}{|l|}{ Rem } & & & \multirow{2}{*}{\multicolumn{4}{|c|}{$\begin{array}{l}\% \text { of GDP } \\
\text { Dummy variable }\end{array}$}} & 2.97 & 4.91 & 4.95 & 1.41 & 34.50 & 0.00 \\
\hline \multicolumn{3}{|c|}{ Banking Crisis } & \multicolumn{2}{|l|}{ Crisis } & \multicolumn{2}{|c|}{ GFDD } & \multirow{2}{*}{\multicolumn{3}{|c|}{ Chinn - Ito Index }} & & 0.14 & 0.34 & 0.20 & 0.30 & 1 & 0 \\
\hline \multicolumn{3}{|c|}{ Financial Openness } & \multicolumn{2}{|l|}{ FO } & \multicolumn{2}{|c|}{ Chinn \& Ito (2006) } & & & & & 0.96 & 1.52 & 1.45 & 0.52 & 2.44 & -1.86 \\
\hline \multicolumn{3}{|c|}{ Trade Openness } & \multirow{2}{*}{\multicolumn{2}{|c|}{$\begin{array}{l}\text { TO } \\
\text { Pol }\end{array}$}} & WEO & & $\%$ of GDP & & & & 42.27 & 21.31 & 20.26 & 6.35 & 156.83 & 6.30 \\
\hline Polity Sco & & & & & Polity IV Pro & & Polity Index & 10 to 10 & & & 6.61 & 4.91 & 5.04 & 1.37 & 10 & -10 \\
\hline Composit & k Rating & & Risk & & ICRG & & Risk Score, & o 100 & & & 72.30 & 8.54 & 8.18 & 3.29 & 92.38 & 36.92 \\
\hline Real GDP & apita & & GDPPC & & WDI & & Thousands & (constant & 05) US\$ & & 13.05 & 15.39 & 14.84 & 1.39 & 67.80 & 0.24 \\
\hline Populatio & & & Pop & & WDI & & Tens of mil & & & & 6.79 & 19.15 & 18.45 & 0.89 & 134.41 & 0.11 \\
\hline Populatio & nsity & & Den & & WDI & & People per & $\mathrm{km}$ of lan & area & & 117.18 & 132.10 & 146.72 & 7.52 & 1085.00 & 2.35 \\
\hline Age Depe & cy Ratio & & Age & & WDI & & $\%$ of workir & age popul & & & 56.87 & 14.20 & 15.01 & 2.90 & 108.21 & 36.04 \\
\hline Correlatio & latrix & & & & & & & & & & & & & & & \\
\hline & $\mathrm{NPL}$ & Growth & $\operatorname{lnf}$ & Rem & Crisis & FO & TO & Pol & Risk & GDPPC & Pop & Den & Age & & & \\
\hline NPL & 1.0000 & & & & & & & & & & & & & & & \\
\hline Growth & -0.1198 & 1.0000 & & & & & & & & & & & & & & \\
\hline Inf & 0.1996 & -0.0132 & 1.0000 & & & & & & & & & & & & & \\
\hline Rem & 0.1051 & 0.0855 & 0.0245 & 1.0000 & & & & & & & & & & & & \\
\hline Crisis & 0.1827 & -0.3192 & 0.0911 & -0.1150 & 1.0000 & & & & & & & & & & & \\
\hline FO & -0.4107 & -0.1493 & -0.3218 & -0.1185 & 0.0754 & 1.0000 & & & & & & & & & & \\
\hline то & -0.1008 & 0.1502 & -0.0417 & 0.4475 & -0.0140 & 0.0505 & 1.0000 & & & & & & & & & \\
\hline Pol & -0.3174 & -0.1158 & -0.1602 & -0.1367 & 0.1148 & 0.3396 & 0.0383 & 1.0000 & & & & & & & & \\
\hline Risk & -0.5185 & 0.0144 & -0.4391 & -0.3362 & -0.0224 & 0.5018 & 0.0532 & 0.3019 & 1.0000 & & & & & & & \\
\hline GDPPC & -0.4082 & -0.2085 & -0.2698 & -0.3512 & 0.1891 & 0.5560 & -0.0835 & 0.4008 & 0.7644 & 1.0000 & & & & & & \\
\hline Pop & 0.0748 & 0.1689 & -0.0102 & -0.0747 & -0.0324 & -0.2495 & -0.2403 & -0.1808 & -0.0427 & -0.1122 & 1.0000 & & & & & \\
\hline Den & 0.0925 & -0.0013 & -0.1069 & 0.1444 & 0.0398 & -0.0157 & 0.0211 & 0.1347 & 0.0445 & 0.1080 & 0.2069 & 1.0000 & & & & \\
\hline Age & 0.2810 & -0.0904 & 0.0949 & 0.2311 & -0.1313 & -0.1884 & -0.1993 & -0.2600 & -0.4626 & -0.3747 & -0.0822 & -0.0428 & 1.0000 & & & \\
\hline
\end{tabular}


Table 7b. Determinants of Banking Sector Stability

\begin{tabular}{|c|c|c|c|c|c|c|c|c|}
\hline \multirow[b]{2}{*}{ Variables } & \multirow[b]{2}{*}{ OLS } & \multirow[b]{2}{*}{$\mathrm{FE}$} & \multicolumn{2}{|c|}{ Exogenous } & \multicolumn{2}{|c|}{ Predetermined } & \multicolumn{2}{|c|}{ Endogenous } \\
\hline & & & D GMM & S GMM & D GMM & S GMM & D GMM & S GMM \\
\hline \multicolumn{9}{|l|}{ Lags } \\
\hline Non Performing Loans $(\mathrm{t}-1)$ & $\begin{array}{c}0.7471 * * * \\
(0.0182)\end{array}$ & $\begin{array}{c}0.5739 * * * \\
(0.0232)\end{array}$ & $\begin{array}{c}0.7054^{* * *} \\
(0.0520)\end{array}$ & $\begin{array}{c}0.7843 * * * \\
(0.0541)\end{array}$ & $\begin{array}{c}0.7248^{* * *} \\
(0.0653)\end{array}$ & $\begin{array}{c}0.7530^{* * *} \\
(0.0544)\end{array}$ & $\begin{array}{c}0.6647^{* * *} \\
(0.0729)\end{array}$ & $\begin{array}{c}0.7294 * * * \\
(0.0503)\end{array}$ \\
\hline \multicolumn{9}{|l|}{ Policy variables } \\
\hline \multicolumn{9}{|l|}{ Macroeconomic variables } \\
\hline Growth & $\begin{array}{c}-0.1928 * * * \\
(0.0326)\end{array}$ & $\begin{array}{c}-0.1674 * * * \\
(0.0358)\end{array}$ & $\begin{array}{c}-0.1405^{* * *} \\
(0.0465)\end{array}$ & $\begin{array}{c}-0.1139 * * * \\
(0.0424)\end{array}$ & $\begin{array}{c}-0.1462 * * * \\
(0.0482)\end{array}$ & $\begin{array}{c}-0.1490 * * * \\
(0.0527)\end{array}$ & $\begin{array}{c}-0.2506 * \\
(0.1353)\end{array}$ & $\begin{array}{c}-0.2249 * * \\
(0.1033)\end{array}$ \\
\hline Inflation & $\begin{array}{l}-0.0243 \\
(0.0154)\end{array}$ & $\begin{array}{c}0.0209 \\
(0.0178)\end{array}$ & $\begin{array}{l}-0.0172 \\
(0.0246)\end{array}$ & $\begin{array}{c}-0.0309 \\
(0.0224)\end{array}$ & $\begin{array}{l}-0.0207 \\
(0.0152)\end{array}$ & $\begin{array}{c}-0.0279 * \\
(0.0153)\end{array}$ & $\begin{array}{c}-0.0251 \\
(0.0361)\end{array}$ & $\begin{array}{l}-0.0454 \\
(0.0324)\end{array}$ \\
\hline Remittance Inflows & $\begin{array}{c}-0.0121 \\
(0.0262)\end{array}$ & $\begin{array}{c}-0.1532 * \\
(0.0786)\end{array}$ & $\begin{array}{l}-0.0666 \\
(0.0791)\end{array}$ & $\begin{array}{c}-0.0295 \\
(0.0265)\end{array}$ & $\begin{array}{c}0.2684 \\
(0.1981)\end{array}$ & $\begin{array}{l}-0.0451 \\
(0.1419)\end{array}$ & $\begin{array}{c}0.1663 \\
(0.1757)\end{array}$ & $\begin{array}{c}0.1094 \\
(0.1805)\end{array}$ \\
\hline Banking Crisis Dummy & $\begin{array}{c}1.4175^{* * *} \\
(0.3473)\end{array}$ & $\begin{array}{c}1.7326 * * * \\
(0.3883)\end{array}$ & $\begin{array}{c}0.2565 \\
(0.5959)\end{array}$ & $\begin{array}{c}0.2407 \\
(0.5961)\end{array}$ & $\begin{array}{l}-0.6294 \\
(1.0613)\end{array}$ & $\begin{array}{c}0.9631 \\
(0.8136)\end{array}$ & $\begin{array}{c}0.8527 \\
(1.6745)\end{array}$ & $\begin{array}{c}0.7766 \\
(1.0107)\end{array}$ \\
\hline \multicolumn{9}{|l|}{ Openness variables } \\
\hline Financial Openness & $\begin{array}{c}-0.1646 * \\
(0.0863)\end{array}$ & $\begin{array}{c}0.5861^{* * *} \\
(0.2003)\end{array}$ & $\begin{array}{c}0.1827 \\
(0.2116)\end{array}$ & $\begin{array}{c}-0.1191 \\
(0.1319)\end{array}$ & $\begin{array}{c}-0.6295 \\
(0.8694)\end{array}$ & $\begin{array}{c}0.3345 \\
(0.2970)\end{array}$ & $\begin{array}{c}0.4976 \\
(0.9667)\end{array}$ & $\begin{array}{c}0.1717 \\
(0.2667)\end{array}$ \\
\hline Trade Openness & $\begin{array}{c}0.0081 \\
(0.0060)\end{array}$ & $\begin{array}{c}-0.0392^{* *} \\
(0.0197)\end{array}$ & $\begin{array}{c}0.0296 \\
(0.0243)\end{array}$ & $\begin{array}{c}0.0157^{* *} \\
(0.0069)\end{array}$ & $\begin{array}{c}0.0083 \\
(0.1065)\end{array}$ & $\begin{array}{l}0.0466^{*} \\
(0.0252)\end{array}$ & $\begin{array}{l}-0.0868 \\
(0.1033)\end{array}$ & $\begin{array}{c}0.0059 \\
(0.0301)\end{array}$ \\
\hline \multicolumn{9}{|l|}{ Institutional variables } \\
\hline Polity Score & $\begin{array}{c}-0.0800^{* * *} \\
(0.0239)\end{array}$ & $\begin{array}{c}0.1649 * * \\
(0.0807)\end{array}$ & $\begin{array}{l}0.1735^{*} \\
(0.0957)\end{array}$ & $\begin{array}{c}-0.0411 \\
(0.0350)\end{array}$ & $\begin{array}{c}-0.0775 \\
(0.2747)\end{array}$ & $\begin{array}{c}0.1410 \\
(0.0981)\end{array}$ & $\begin{array}{l}-0.0938 \\
(0.3390)\end{array}$ & $\begin{array}{c}0.0793 \\
(0.1525)\end{array}$ \\
\hline Composite Risk Rating & $\begin{array}{c}-0.1035^{* * *} \\
(0.0251)\end{array}$ & $\begin{array}{c}-0.2036 * * * \\
(0.0407)\end{array}$ & $\begin{array}{l}-0.0682 \\
(0.0570)\end{array}$ & $\begin{array}{c}-0.0688^{*} \\
(0.0412)\end{array}$ & $\begin{array}{l}-0.0739 \\
(0.0879)\end{array}$ & $\begin{array}{l}-0.1007 \\
(0.0806)\end{array}$ & $\begin{array}{l}-0.1688 \\
(0.1384)\end{array}$ & $\begin{array}{l}-0.2175^{*} \\
(0.1204)\end{array}$ \\
\hline \multicolumn{9}{|l|}{ Structural variables } \\
\hline Income Level & $\begin{array}{c}0.0051 \\
(0.0126)\end{array}$ & $\begin{array}{c}0.0972 \\
(0.1063)\end{array}$ & $\begin{array}{c}0.2494^{* *} \\
(0.1101)\end{array}$ & $\begin{array}{c}0.0074 \\
(0.0145)\end{array}$ & $\begin{array}{c}0.3237^{* *} \\
(0.1570)\end{array}$ & $\begin{array}{l}-0.0234 \\
(0.0330)\end{array}$ & $\begin{array}{c}0.0746 \\
(0.1745)\end{array}$ & $\begin{array}{c}0.0234 \\
(0.0536)\end{array}$ \\
\hline Population & $\begin{array}{c}-0.0019 \\
(0.0060)\end{array}$ & $\begin{array}{c}-0.0187 \\
(0.1312)\end{array}$ & $\begin{array}{c}-0.0053 \\
(0.1711)\end{array}$ & $\begin{array}{c}-0.0020 \\
(0.0047)\end{array}$ & $\begin{array}{l}-0.0053 \\
(0.1926)\end{array}$ & $\begin{array}{c}0.0252^{* *} \\
(0.0123)\end{array}$ & $\begin{array}{c}0.0572 \\
(0.2403)\end{array}$ & $\begin{array}{c}0.0165 \\
(0.0149)\end{array}$ \\
\hline Population Density & 0.0000 & $-0.0658 * * *$ & $-0.0425^{*}$ & -0.0004 & -0.0435 & -0.0012 & -0.0579 & -0.0019 \\
\hline & $(0.0008)$ & $(0.0184)$ & $(0.0217)$ & $(0.0007)$ & $(0.0406)$ & $(0.0019)$ & $(0.0368)$ & $(0.0020)$ \\
\hline Age Dependency & $\begin{array}{l}-0.0048 \\
(0.0088)\end{array}$ & $\begin{array}{c}0.0460 \\
(0.0487)\end{array}$ & $\begin{array}{c}0.0979 * * \\
(0.0486)\end{array}$ & $\begin{array}{c}0.0083 \\
(0.0123)\end{array}$ & $\begin{array}{c}0.1533 * * \\
(0.0761)\end{array}$ & $\begin{array}{c}0.0250 \\
(0.0249)\end{array}$ & $\begin{array}{c}0.0485 \\
(0.0852)\end{array}$ & $\begin{array}{l}-0.0174 \\
(0.0336)\end{array}$ \\
\hline Constant & $\begin{array}{c}11.0748^{* * *} \\
(2.0753) \\
\end{array}$ & $\begin{array}{c}23.0256^{* * *} \\
(4.8616) \\
\end{array}$ & & $\begin{array}{l}6.4071^{*} \\
(3.4601) \\
\end{array}$ & & $\begin{array}{c}6.9377 \\
(7.2672) \\
\end{array}$ & & $\begin{array}{l}18.9677^{*} \\
(10.0003)\end{array}$ \\
\hline Observations & 929 & 929 & 906 & 991 & 896 & 981 & 844 & 929 \\
\hline R-squared & 0.8238 & 0.7113 & & & & & & \\
\hline Time Dummies & YES & YES & YES & YES & YES & YES & YES & YES \\
\hline Number of countries & & 85 & 84 & 85 & 84 & 85 & 84 & 85 \\
\hline Number of instruments & & & 38 & 40 & 71 & 81 & 70 & 80 \\
\hline Hansen Test & & & 0.224 & 0.182 & 0.529 & 0.376 & 0.310 & 0.401 \\
\hline $\mathrm{AR}(1)$ & & & 0.00246 & 0.00248 & 0.00367 & 0.00412 & 0.00167 & 0.00142 \\
\hline$A R(2)$ & & & 0.198 & 0.201 & 0.347 & 0.314 & 0.0870 & 0.0987 \\
\hline
\end{tabular}

Standard errors in parentheses

*** $p<0.01,{ }^{* *} p<0.05, * p<0.1$ 
Table 7c. Robustness Checks: Determinants of Banking Sector Stability

\begin{tabular}{|c|c|c|c|c|c|c|c|c|c|c|c|c|c|c|c|c|c|c|}
\hline \multirow[b]{3}{*}{ Variables } & \multicolumn{6}{|c|}{ Developing Countries } & \multirow{2}{*}{\multicolumn{6}{|c|}{ Pre-GFC (upto 2007) }} & \multicolumn{6}{|c|}{$\begin{array}{l}\text { Trimmed Sample } \\
\end{array}$} \\
\hline & \multicolumn{2}{|c|}{$\begin{array}{l}\text { Exogenous } \\
\end{array}$} & \multicolumn{2}{|c|}{ Predetermined } & \multirow{2}{*}{\multicolumn{2}{|c|}{$\begin{array}{l}\text { Endogenous } \\
\end{array}$}} & Exogenous & & & & & Endogenous & \multicolumn{2}{|c|}{ Exogenous } & \multirow{2}{*}{\multicolumn{2}{|c|}{ Predetermined }} & \multicolumn{2}{|c|}{ Endogenous } \\
\hline & D GMM & SGMM & D GMM & S GMM & & SGMM & D GMM & SGMM & \multicolumn{2}{|c|}{ Predetermined } & D GMM & SGMM & D GMM & SGMM & & & D GMM & SGMM \\
\hline \multicolumn{19}{|l|}{ Lags } \\
\hline Non Performing Loans ( $\mathrm{t}-1)$ & $\begin{array}{c}0.7083^{* * *} \\
(0.0737)\end{array}$ & $\begin{array}{c}0.8001^{* * *} \\
(0.0694)\end{array}$ & $\begin{array}{c}0.6823^{* * *} \\
(0.1337)\end{array}$ & $\begin{array}{c}0.8100^{* * *} \\
(0.0854)\end{array}$ & $\begin{array}{c}0.6854^{* * *} \\
(0.0908)\end{array}$ & $\begin{array}{c}0.7091^{* * *} \\
(0.0848)\end{array}$ & \begin{tabular}{|c}
$0.7721 * * *$ \\
$(0.0769)$
\end{tabular} & $\begin{array}{c}0.8490^{* * *} \\
(0.0833)\end{array}$ & $\begin{array}{c}0.6691 * * * \\
(0.0725)\end{array}$ & $\begin{array}{c}0.7417^{* * *} \\
(0.0623)\end{array}$ & $\begin{array}{c}0.6751^{* * *} \\
(0.0827)\end{array}$ & $\begin{array}{c}0.7125 * * * \\
(0.0626)\end{array}$ & $\begin{array}{c}0.7363^{* * *} \\
(0.0581)\end{array}$ & $\begin{array}{c}0.9188^{* * *} \\
(0.0473)\end{array}$ & $\begin{array}{c}0.7879 * * * \\
(0.0844)\end{array}$ & $\begin{array}{c}0.8975 * * * \\
(0.0462)\end{array}$ & $\begin{array}{c}0.6658^{* * *} \\
(0.0973)\end{array}$ & $\begin{array}{c}0.8377 * * * \\
(0.0533)\end{array}$ \\
\hline \multicolumn{19}{|l|}{$\begin{array}{l}\text { Policy variables } \\
\text { Macroeconomic variables }\end{array}$} \\
\hline \multirow[t]{2}{*}{ Growth } & -0.0901 & -0.0391 & -0.0340 & 0.0269 & -0.3211 & -0.0737 & -0.1149 & -0.0784 & -0.1891 & -0.1137 & -0.1296 & -0.1050 & $-0.1375 * * *$ & $-0.1091^{* * *}$ & $-0.1728^{* * *}$ & $-0.1572^{* * *}$ & $-0.2776^{* *}$ & $-0.2826^{* *}$ \\
\hline & $(0.0731)$ & $(0.0624)$ & $(0.0785)$ & $(0.0823)$ & $(0.2712)$ & $(0.2263)$ & $(0.0949)$ & $(0.0728)$ & $(0.1428)$ & $(0.1021)$ & $(0.1645)$ & $(0.1103)$ & $(0.0360)$ & $(0.0375)$ & $(0.0449)$ & $(0.0496)$ & $(0.1285)$ & $(0.1208)$ \\
\hline \multirow[t]{2}{*}{ Inflation } & -0.0081 & -0.0286 & 0.0101 & -0.0203 & -0.0369 & -0.0806 & -0.0041 & -0.0126 & -0.0167 & -0.0114 & 0.0135 & 0.0303 & 0.0059 & -0.0045 & $-0.0278^{* *}$ & $-0.0255^{* *}$ & -0.0206 & -0.0581 \\
\hline & $(0.0266)$ & $(0.0228)$ & $(0.0273)$ & $(0.0211)$ & (0.0489) & (0.0514) & $(0.0277)$ & $(0.0224)$ & $(0.0180)$ & (0.0198) & $(0.0380)$ & $(0.0315)$ & $(0.0158)$ & $(0.0143)$ & $(0.0126)$ & $(0.0119)$ & $(0.0562)$ & $(0.0409)$ \\
\hline \multirow{2}{*}{ Remittance Inflows } & -0.0340 & -0.0139 & -0.1791 & 0.0602 & 0.0355 & 0.2506 & 0.0129 & 0.0058 & 0.0723 & $-0.2158^{*}$ & 0.2816 & -0.0936 & -0.0864 & -0.0219 & 0.2026 & -0.0341 & 0.1853 & 0.1290 \\
\hline & $(0.0786)$ & $(0.0347)$ & $(0.2668)$ & $(0.2099)$ & (0.2054) & $(0.2786)$ & $(0.1607)$ & $(0.0250)$ & $(0.2925)$ & $(0.1268)$ & $(0.2416)$ & $(0.1487)$ & $(0.0770)$ & (0.0219) & (0.1744) & (0.1424) & $(0.1716)$ & $(0.1630)$ \\
\hline \multirow[t]{2}{*}{ Banking Crisis Dummy } & 0.0346 & 0.5806 & 2.1513 & 1.8416 & 1.0325 & 1.4625 & -0.4731 & -1.0871 & 0.3721 & 0.0780 & 1.7203 & 0.9683 & 0.2823 & 0.0881 & -0.9528 & 0.8704 & 0.1408 & 0.6562 \\
\hline & $(1.3010)$ & $(1.3315)$ & (2.0189) & (1.6924) & (2.9731) & (3.0218) & $(1.2630)$ & (1.0204) & (1.4185) & (1.1876) & (1.6351) & (1.6678) & $(0.5091)$ & $(0.4756)$ & $(0.9221)$ & $(0.7243)$ & (1.6149) & $(0.8647)$ \\
\hline Openness variables & & & & & & & & & & & & & & & & & & \\
\hline Financial Openness & 0.1073 & -0.1458 & -0.4186 & 0.1248 & -0.7937 & -0.1065 & 0.0115 & -0.1498 & 0.0716 & -0.1298 & 0.7668 & -0.1202 & 0.2231 & -0.0263 & -0.6358 & 0.2485 & 0.3383 & 0.0465 \\
\hline & $(0.2766)$ & $(0.1681)$ & (1.2558) & (0.3996) & (1.1375) & (0.5543) & $(0.2410)$ & $(0.1285)$ & $(0.6253)$ & $(0.3378)$ & $(0.8150)$ & $(0.3744)$ & $(0.1901)$ & (0.1044) & $(0.8828)$ & $(0.2570)$ & $(0.9895)$ & $(0.2273)$ \\
\hline Trade Openness & 0.0214 & 0.0119 & -0.0733 & 0.0583 & -0.1205 & -0.0355 & 0.0218 & -0.0013 & -0.0346 & 0.0457 & -0.0945 & -0.0066 & 0.0302 & $0.0155^{* *}$ & 0.0094 & $0.0632^{* * *}$ & -0.0059 & 0.0138 \\
\hline & $(0.0252)$ & $(0.0115)$ & $(0.1847)$ & $(0.0471)$ & $(0.1647)$ & $(0.0657)$ & $(0.0520)$ & $(0.0071)$ & $(0.1006)$ & (0.0311) & $(0.1282)$ & (0.0312) & $(0.0234)$ & $(0.0061)$ & (0.0813) & $(0.0212)$ & (0.0709) & $(0.0248)$ \\
\hline Institutional variables & & & & & & & & & & & & & & & & & & \\
\hline Polity Score & $0.2258^{* *}$ & -0.0519 & -0.4685 & -0.0419 & -0.2046 & -0.0309 & 0.1515 & -0.0232 & 0.1486 & 0.1499 & 0.2515 & 0.0266 & $0.1423^{*}$ & -0.0108 & -0.1856 & 0.1253 & -0.6822 & 0.1374 \\
\hline & $(0.0988)$ & $(0.0447)$ & $(0.4694)$ & $(0.1372)$ & (0.3912) & $(0.1693)$ & (0.1504) & $(0.0505)$ & $(0.2360)$ & $(0.0996)$ & $(0.2724)$ & $(0.1704)$ & (0.0849) & (0.0229) & $(0.2675)$ & $(0.0996)$ & $(0.4604)$ & $(0.1492)$ \\
\hline Composite Risk Rating & -0.0950 & -0.0401 & 0.1403 & 0.0980 & -0.1916 & -0.3970 & 0.1098 & 0.0317 & -0.0789 & -0.0546 & -0.0277 & -0.0763 & -0.0652 & -0.0329 & -0.0392 & 0.0287 & $-0.3194^{*}$ & -0.1526 \\
\hline & $(0.0750)$ & $(0.0510)$ & (0.1879) & $(0.1740)$ & $(0.2896)$ & (0.2629) & $(0.0799)$ & $(0.0463)$ & $(0.1154)$ & (0.0996) & $(0.1461)$ & $(0.0985)$ & $(0.0580)$ & (0.0379) & $(0.1008)$ & $(0.0748)$ & $(0.1709)$ & $(0.1394)$ \\
\hline Structural variables & & & & & & & & & & & & & & & & & & \\
\hline Income Level & $1.3374^{* *}$ & 0.0049 & 1.5127 & -0.0294 & 0.8443 & 0.2535 & $0.4858^{* *}$ & -0.0116 & $0.4425 * *$ & -0.0202 & $0.3897^{*}$ & -0.0106 & $0.1908^{*}$ & 0.0106 & $0.3004 * *$ & -0.0398 & -0.0713 & 0.0182 \\
\hline & $(0.5617)$ & $(0.1100)$ & (1.1490) & $(0.1830)$ & $(1.0743)$ & $(0.4295)$ & $(0.1863)$ & $(0.0167)$ & $(0.1777)$ & $(0.0389)$ & $(0.2197)$ & $(0.0340)$ & $(0.1065)$ & $(0.0134)$ & $(0.1423)$ & $(0.0344)$ & $(0.1591)$ & (0.0602) \\
\hline Population & 0.0553 & -0.0070 & -0.0615 & 0.0095 & 0.1295 & 0.0139 & -0.0656 & -0.0025 & -0.0124 & 0.0201 & 0.0438 & 0.0022 & 0.0938 & -0.0034 & 0.1060 & $0.0243^{* *}$ & 0.1025 & 0.0164 \\
\hline & (0.1929) & $(0.0069)$ & (0.2915) & $(0.0157)$ & $(0.2707)$ & $(0.0167)$ & (0.1914) & $(0.0044)$ & $(0.2523)$ & $(0.0175)$ & (0.2908) & $(0.0176)$ & $(0.0849)$ & $(0.0051)$ & (0.1106) & $(0.0109)$ & $(0.1280)$ & $(0.0125)$ \\
\hline Population Density & -0.0428 & 0.0000 & & -0.0013 & -0.0480 & & & & & & & & $-0.0487^{* *}$ & $-0.0012^{* *}$ & & $-0.0031^{*}$ & -0.0242 & $-0.0040^{* *}$ \\
\hline & $(0.0304)$ & $(0.0010)$ & $(0.0655)$ & $(0.0034)$ & $(0.0513)$ & $(0.0047)$ & (0.0338) & $(0.0010)$ & $(0.0406)$ & $(0.0012)$ & $(0.0445)$ & $(0.0012)$ & $(0.0238)$ & $(0.0005)$ & $(0.0403)$ & $(0.0018)$ & $(0.0394)$ & $(0.0019)$ \\
\hline Age Dependency & 0.1235 & 0.0091 & 0.0318 & 0.0439 & 0.1627 & -0.0284 & 0.1179 & $0.0335^{*}$ & 0.1320 & $0.0689^{*}$ & 0.1687 & 0.0319 & $0.0763^{*}$ & 0.0036 & $0.1309^{*}$ & 0.0344 & -0.0019 & -0.0138 \\
\hline & $(0.0972)$ & $(0.0159)$ & (0.1953) & $(0.0378)$ & (0.1743) & $(0.0377)$ & (0.1164) & (0.0174) & $(0.1340)$ & $(0.0386)$ & (0.1206) & $(0.0425)$ & $(0.0453)$ & $(0.0083)$ & $(0.0690)$ & $(0.0222)$ & $(0.0971)$ & $(0.0305)$ \\
\hline Constant & & 4.0450 & & -8.7418 & & 33.6380 & & -3.0486 & & 1.3064 & & 5.5114 & & 2.4328 & & -4.5924 & & 11.7252 \\
\hline 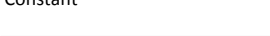 & & $(3.8702)$ & & (15.7129) & & $\begin{array}{l}20.4669) \\
(20.060)\end{array}$ & & $(4.3087)$ & & $\begin{array}{l}1.5004 \\
(8.9585)\end{array}$ & & $\begin{array}{l}2.5114 \\
(8.5080)\end{array}$ & & $\begin{array}{l}2.4520 \\
(3.0158)\end{array}$ & & $\begin{array}{l}(6.7236) \\
(6.723\end{array}$ & & $(11.7403)$ \\
\hline Observations & 506 & 555 & 504 & 553 & 472 & 521 & 530 & 612 & 520 & 602 & 533 & 615 & 844 & 929 & 835 & 920 & 784 & 869 \\
\hline Time Dummie & YES & YES & YES & YES & YES & YES & YES & YES & YES & YES & YES & YES & YES & YES & YES & YES & YES & YES \\
\hline Number of countries & 48 & 49 & 48 & 49 & 48 & 49 & 81 & 82 & 80 & 82 & 81 & 82 & 84 & 85 & 84 & 85 & 84 & 85 \\
\hline Number of instruments & 38 & 40 & 35 & 45 & 34 & 44 & 28 & 30 & 66 & 76 & 66 & 76 & 38 & 40 & 71 & 81 & 70 & 80 \\
\hline Hansen Test & 0.362 & 0.135 & 0.185 & 0.0959 & 0.205 & 0.164 & 0.275 & 0.251 & 0.645 & 0.628 & 0.414 & 0.406 & 0.962 & 0.00411 & 0.405 & 0.177 & 0.411 & 0.0317 \\
\hline $\mathrm{AR}(1)$ & 0.00698 & 0.00726 & 0.00528 & 0.00482 & 0.0178 & 0.0127 & 0.0119 & 0.0116 & 0.0248 & 0.0235 & 0.0148 & 0.00965 & 0.00306 & 0.00164 & 0.00123 & 0.00112 & 0.00115 & 0.00332 \\
\hline $\operatorname{AR}(2)$ & 0.250 & 0.278 & 0.313 & 0.282 & 0.0948 & 0.315 & 0.271 & 0.245 & 0.569 & 0.488 & 0.160 & 0.163 & 0.0175 & 0.0178 & 0.0670 & 0.0326 & 0.114 & 0.111 \\
\hline
\end{tabular}


Table 8. The Impact of Policy Variables on the Different Dimensions of Financial Development

\begin{tabular}{|c|c|c|c|c|c|c|}
\hline \multirow[b]{3}{*}{ Policy variable } & \multicolumn{3}{|c|}{ Using Gap Analysis } & \multicolumn{3}{|c|}{$\begin{array}{c}\text { Regression with Structural } \\
\text { Controls } \\
\end{array}$} \\
\hline & \multicolumn{3}{|c|}{ effect on } & \multicolumn{3}{|c|}{ effect on } \\
\hline & Depth & Efficiency & Stability & Depth & Efficiency & Stability \\
\hline \multicolumn{7}{|l|}{ Macroeconomic variables } \\
\hline Growth & $\uparrow$ & - & $\uparrow$ & $\uparrow$ & - & $\uparrow$ \\
\hline Inflation & - & $\downarrow$ & $\uparrow$ & - & $\downarrow$ & - \\
\hline Remittance Inflows & - & - & - & - & - & - \\
\hline Banking Crisis Dummy & $\downarrow$ & - & $\downarrow$ & $\downarrow$ & - & - \\
\hline \multicolumn{7}{|l|}{ Openness variables } \\
\hline Financial Openness & - & - & - & - & - & - \\
\hline Trade Openness & $\uparrow$ & - & $\downarrow$ & $\uparrow$ & - & $\downarrow$ \\
\hline \multicolumn{7}{|l|}{ Institutional variables } \\
\hline Polity Score & - & - & - & - & - & - \\
\hline Composite Risk Rating & $\uparrow$ & $\uparrow$ & $\uparrow$ & $\uparrow$ & 个 & $\uparrow$ \\
\hline \multicolumn{7}{|l|}{ Market power } \\
\hline Lerner Index & & - & & & $\downarrow$ & \\
\hline
\end{tabular}




\section{REFERENCES}

Acemoglu, Daron, Simon Johnson, and James A. Robinson. "Institutions as a fundamental cause of long-run growth." Handbook of economic growth 1 (2005): 385-472.

Aggarwal, Reena, Aslı Demirgüç-Kunt, and Maria Soledad Martínez Pería. "Do remittances promote financial development?" Journal of development economics 96.2 (2011): 255-264.

Aghion, Philippe, Peter Howitt, and David Mayer-Foulkes. "The Effect of Financial Development on Convergence: Theory and Evidence." The quarterly journal of economics 120.1 (2005): 173-222.

Arcand, Jean-Louis, Enrico Berkes, and Ugo Panizza. "Too much finance?" International Monetary Fund working paper 12/161 (2012).

Arellano, Manuel, and Olympia Bover. "Another look at the instrumental variable estimation of error-components models." Journal of econometrics 68.1 (1995): 29-51.

Arellano, Manuel, and Stephen Bond. "Some tests of specification for panel data: Monte Carlo evidence and an application to employment equations." The review of economic studies 58.2 (1991): 277-297.

Bagehot, Walter. Lombard Street: A Description of the Money Market. Scribner, Armstrong \& Co., 1873.

Baltagi, Badi H., Panicos O. Demetriades, and Siong Hook Law. "Financial development and openness: Evidence from panel data." Journal of development economics 89.2 (2009): 285-296.

Baltagi, Badi. Econometric analysis of panel data. Vol. 1. John Wiley \& Sons, 2008.

Barajas, Adolfo, Thorsten Beck, Era Dabla-Norris, and Seyed Reza Yousefi. "Too Cold, Too Hot, Or Just Right? Assessing Financial Sector Development Across the Globe." International Monetary Fund working paper 13/81 (2013). [Barajas et al 2013a]

Barajas, Adolfo, Ralph Chami, and Seyed Reza Yousefi. "The Finance and Growth Nexus Re-Examined: Do All Countries Benefit Equally?" International Monetary Fund working paper 13/130 (2013). [Barajas et al 2013b]

Beck, Thorsten, and Augusto de la Torre. "The basic analytics of access to financial services." Financial markets, institutions \& instruments 16.2 (2007): 79-117.

Beck, Thorsten, and Erik Feyen. "Benchmarking Financial Systems: Introducing the Financial Possibility Frontier." World Bank Policy Research working paper 6615 (2013).

Beck, Thorsten, Aslı Demirgüç-Kunt, and Ross Levine. "Finance, inequality and the 
poor." Journal of economic growth 12.1 (2007): 27-49.

Beck, Thorsten, Aslı Demirgüç-Kunt, and Ross Levine. "Financial institutions and markets across countries and over time: The updated financial development and structure database." The World Bank economic review 24.1 (2010): 77-92.

Beck, Thorsten, Erik Feyen, Alain Ize, and Florencia Moizeszowicz. "Benchmarking financial development." World Bank Policy Research working paper 4638 (2008).

Beck, Thorsten, Ross Levine, and Norman Loayza. "Finance and the Sources of Growth." Journal of financial economics 58.1 (2000): 261-300.

Beck, Thorsten, Tao Chen, Chen Lin, and Frank Song. "Financial innovation: The bright and the dark sides." Hong Kong Institute for Monetary Research working paper 5 (2012)

Beck, Thorsten. "Bank competition and financial stability: friends or foes?" World Bank Policy Research working paper 4656 (2008).

Beck, Thorsten. "The Role of Finance in Economic Development-Benefits, Risks, and Politics." Oxford handbook of capitalism (2012).

Bencivenga, Valerie R., and Bruce D. Smith. "Financial intermediation and endogenous growth." The review of economic studies 58.2 (1991): 195-209.

Benmelech, Efraim, and Tobias J. Moskowitz. "The political economy of financial regulation: evidence from US state usury laws in the 19th century." The journal of finance 65.3 (2010): 1029-1073.

Blundell, Richard, and Stephen Bond. "Initial conditions and moment restrictions in dynamic panel data models." Journal of econometrics 87.1 (1998): 115-143.

Bond, Stephen R. "Dynamic panel data models: a guide to micro data methods and practice." Portuguese economic journal 1.2 (2002): 141-162.

Boyd, John H., Ross Levine, and Bruce D. Smith. "The impact of inflation on financial sector performance." Journal of monetary economics 47.2 (2001): 221-248.

Chinn, Menzie D., and Hiro Ito. "A new measure of financial openness." Journal of comparative policy analysis 10.3 (2008): 309-322.

Chinn, Menzie D., and Hiro Ito. "What matters for financial development? Capital controls, institutions, and interactions." Journal of development economics 81.1 (2006): 163-192.

Čihák, Martin, Aslı Demirgüç-Kunt, Erik Feyen, and Ross Levine. "Benchmarking financial systems around the world." World Bank Policy Research working paper 6175 (2012). 
Claessens, Stijn, Gergely Dobos, Daniela Klingebiel, and Luc Laeven. "The Growing Importance of Networks in Finance and Its Effects on Competition." Innovations in Financial and Economic Networks (2003): 110-135.

Dabla-Norris, Era, and Narapong Srivisal. "Revisiting the Link Between Finance and Macroeconomic Volatility." International Monetary Fund working paper 13/29 (2013).

Demetriades, Panicos O., and Khaled A. Hussein. "Does financial development cause economic growth? Time-series evidence from 16 countries." Journal of development Economics 51.2 (1996): 387-411.

Demetriades, Panicos O., and Siong Hook Law. "Finance, institutions and economic development." International journal of finance \& economics 11.3 (2006): 245-260.

Demetriades, Panicos O., and Svetlana Andrianova. "Sources and effectiveness of financial development: what we know and what we need to know." United Nations University research paper 2005/76 (2005).

Demirgüç-Kunt, Asl1, and Enrica Detragiache. "Cross-country empirical studies of systemic bank distress: a survey." National Institute economic review192.1 (2005): 68-83.

Demirgüç-Kunt, Asl1, and Ross Levine. "Finance, financial sector policies, and long-run growth." World Bank Policy Research working paper series, vol (2008).

Dubey, Pradeep, John Geanakoplos, and Martin Shubik. "Default and punishment in general equilibrium." Econometrica 73.1 (2005): 1-37.

Feyen, Erik, Katie Kibuuka, and Diego Sourrouille. "Fin Stats 2014: A ready-to-use tool to benchmark financial sectors across countries and over time." World Bank Financial Systems Global Practice (2013).

Girma, Sourafel, and Anja Shortland. "The political economy of financial development." Oxford economic papers 60.4 (2008): 567-596.

Goldsmith, Raymond W. Financial structure and economic development. Yale University Press, 1969.

Haber, Stephen, and Enrico Perotti. "The political economy of financial systems." Tinbergen Institute Discussion Paper 08-045/2 (2008).

Hansen, Lars Peter. "Large Sample Properties of Generalized Method of Moments Estimators." Econometrica 50.4 (1982): 1029-54.

Honohan, Patrick. "Financial development, growth, and poverty: how close are the links?" World Bank Policy Research working paper 3203 (2004). 
Jalilian, Hossein, and Colin Kirkpatrick. "Does financial development contribute to poverty reduction?" Journal of development studies 41.4 (2005): 636-656.

Jalilian, Hossein, and Colin Kirkpatrick. "Financial development and poverty reduction in developing countries." International journal of finance \& economics 7.2 (2002): 97-108.

Jeanneney, Sylviane Guillaumont, and Kangni Kpodar. "Financial development and poverty reduction: Can there be a benefit without a cost?" The Journal of development studies 47.1 (2011): 143-163.

King, Robert G., and Ross Levine. "Finance and Growth: Schumpeter Might be Right." The quarterly journal of economics 108.3 (1993): 717-737.

La Porta, Rafael, Florencio Lopez-De-Silanes, Andrei Shleifer, and Robert W. Vishny. "Legal Determinants of External Finance." Journal of finance (1997): 1131-1150.

Levine, Ross, Norman Loayza, and Thorsten Beck. "Financial intermediation and growth: Causality and causes." Journal of monetary economics 46.1 (2000): 31-77.

Levine, Ross, and Sara Zervos. "Stock markets, banks, and economic growth." American economic review 88.3 (1998): 537-558.

Levine, Ross. "Finance and growth: theory and evidence." Handbook of economic growth 1 (2005): 865-934.

Levine, Ross. "Financial development and economic growth: views and agenda." Journal of economic literature (1997): 688-726.

Levine, Ross. "The legal environment, banks, and long-run economic growth." Journal of money, credit and banking (1998): 596-613.

Lucas Jr, Robert E. "On the mechanics of economic development." Journal of the monetary economics 22.1 (1988): 3-42.

McKinnon, Ronald I. Money and capital in economic development. Brookings Institution Press, 1973.

Miller, Merton H. "Financial markets and economic growth." Journal of applied corporate finance 11.3 (1998): 8-15.

Nickell, Stephen J. "Biases in Dynamic Models with Fixed Effects." Econometrica 49.6 (1981): 1417-26.

Peria, Maria Soledad Martinez, and Ashoka Mody. "How foreign participation and market concentration impact bank spreads: evidence from Latin America." Journal of money, credit and banking (2004): 511-537. 
Rajan, Raghuram G. "Has finance made the world riskier?" European financial management 12.4 (2006): 499-533.

Rajan, Raghuram G., and Luigi Zingales. "Financial Dependence and Growth." American economic review 88.3 (1998): 559-586.

Rajan, Raghuram G., and Luigi Zingales. "The great reversals: the politics of financial development in the twentieth century." Journal of financial economics 69.1 (2003): 5-50. Rioja, Felix, and Neven Valev. "Does one size fit all?: a reexamination of the finance and growth relationship." Journal of development economics 74.2 (2004): 429-447.

Roodman, David. "How to do xtabond2: An introduction to difference and system GMM in Stata." Stata journal 9.1 (2009): 86.

Rousseau, Peter L., and Paul Wachtel. "Inflation thresholds and the finance-growth nexus." Journal of international money and finance 21.6 (2002): 777-793.

Sargan, J. D. "The Estimation of Economic Relationships using Instrumental Variables." Econometrica 26.3 (1958): 393-415.

Schumpeter, Joseph Alois. The theory of economic development. Harvard University Press, 1911.

Shaw, Edward S. Financial deepening in economic development. Oxford University Press, 1973.

Shubik, Martin, and Charles Wilson. "The optimal bankruptcy rule in a trading economy using fiat money." Journal of economics 37.3 (1977): 337-354. 